\title{
GEOHYDROLOGY OF THE HIGH PLAINS AQUIFER IN PARTS OF COLORADO, KANSAS, NEBRASKA, NEW MEXICO, OKLAHOMA, SOUTH DAKOTA, TEXAS, AND WYOMING
}

\section{REGIONAL AQUIFER-SYSTEM ANALYSIS}

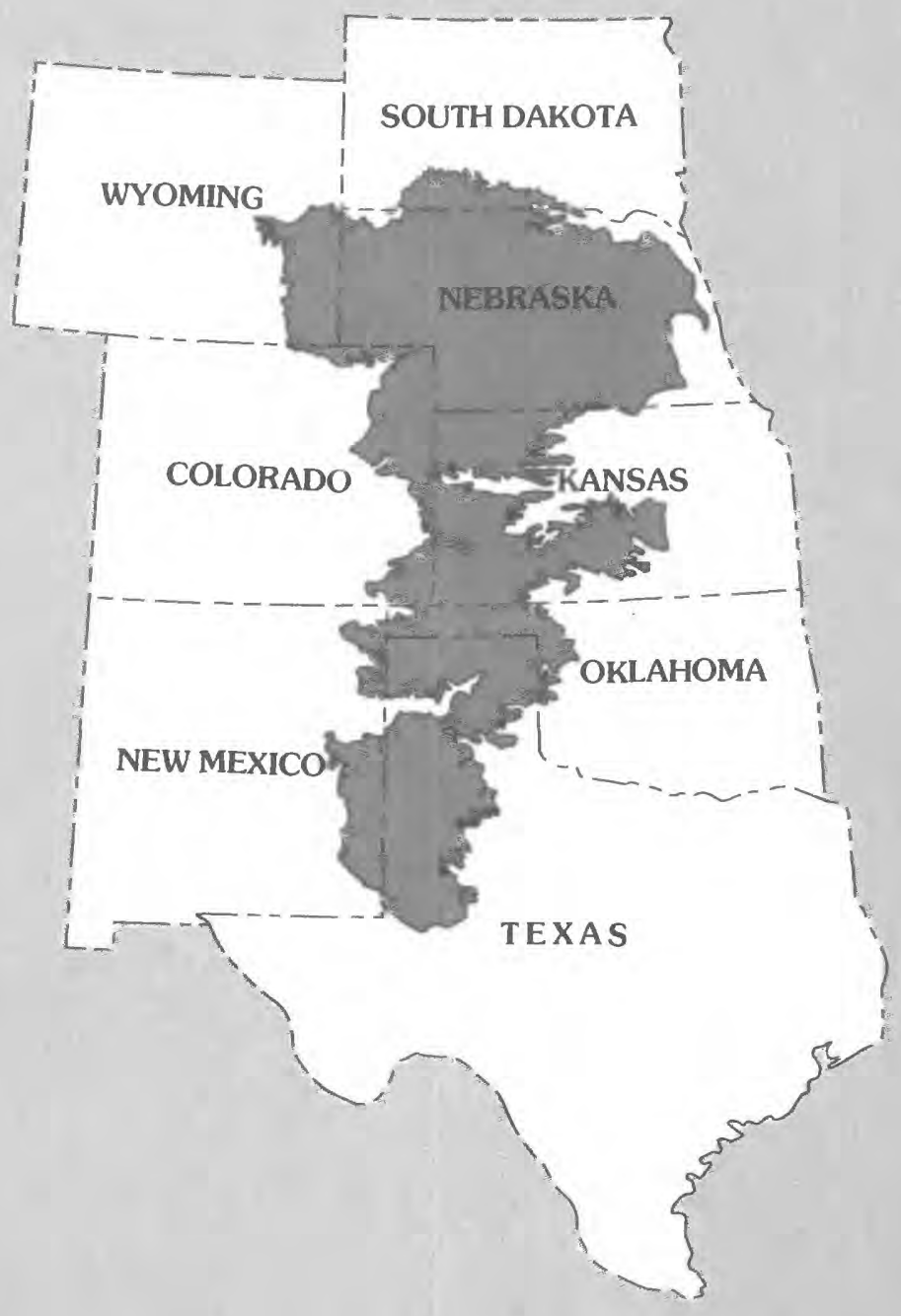




\section{Geohydrology of the High Plains Aquifer In Parts of Colorado, Kansas, Nebraska, New Mexico, Oklahoma, South Dakota, Texas, and Wyoming}

By EDWIN D. GUTENTAG, FREDERICK J. HEIMES, NOEL C. KROTHE, RICHARD R. LUCKEY, and JOHN B. WEEKS

HIGH PLAINS RASA PROJECT

U.S. GEOLOGICAL SURVEY PROFESSIONAL PAPER 1400-B

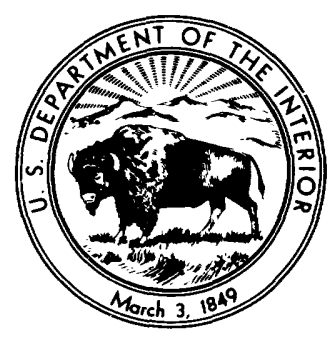

UNITED STATES GOVERNMENT PRINTING OFFICE, WASHINGTON : 1984 


\section{UNITED STATES DEPARTMENT OF THE INTERIOR \\ WILLIAM P. CLARK, Secretary}

\section{GEOLOGICAL SURVEY}

Dallas L. Peck, Director

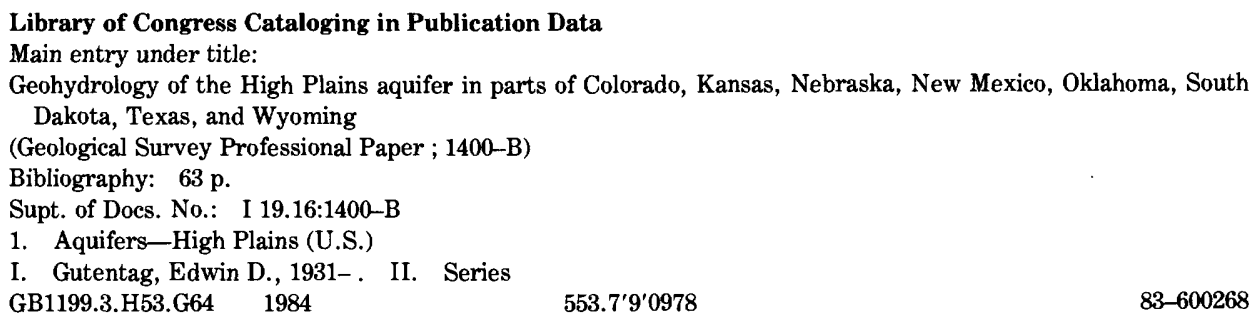

Geohydrology of the High Plains aquifer in parts of Colorado, Kansas, Nebraska, New Mexico, Oklahoma, South Dakota, Texas, and Wyoming

$83-600268$

For sale by the Branch of Distribution

U.S. Geological Survey

604 South Pickett Street

Alexandria, VA 22304 


\section{FOREWORD}

\section{THE REGIONAL AQUIFER-SYSTEM ANALYSIS PROGRAM}

The Regional Aquifer-System Analysis (RASA) program was started in 1978 after a congressional mandate to develop quantitative appraisals of the major ground-water systems of the United States. The RASA program represents a systematic effort to study a number of the Nation's most important aquifer systems which, in aggregate, underlie much of the country and which represent important components of the Nation's total water supply. In general, the boundaries of these studies are identified by the hydrologic extent of each system, and accordingly transcend the political subdivisions to which investigations have often arbitrarily been limited in the past. The broad objective for each study is to assemble geologic, hydrologic, and geochemical information, to analyze and develop an understanding of the system, and to develop predictive capabilities that will contribute to the effective management of the system. The use of computer simulation is an important element of the RASA studies, both to develop an understanding of the natural, undisturbed hydrologic system, and of any changes brought about by human activities, as well as to provide a means of predicting the regional effects of future pumping or other stresses.

The final interpretive results of the RASA program are presented in a series of U.S. Geological Survey Professional Papers that describe the geology, hydrology, and geochemistry of each regional aquifer system. Each study within the RASA program is assigned a single Professional Paper number, and where the volume of interpretive material warrants, separate topical chapters that consider the principal elements of the investigation may be published. The series of RASA interpretive reports begins with Professional Paper 1400 and thereafter will continue in numerical sequence as the interpretive products of subsequent studies become available.

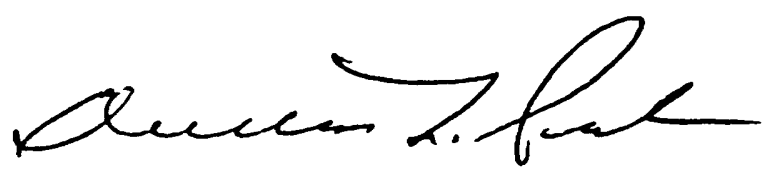

Dallas Peck Director 


\section{-}




\section{PREFACE}

The Regional Aquifer-system Analysis of the High Plains was conducted by U.S. Geological Survey personnel in each of the eight States in the High Plains-Colorado, Kansas, Nebraska, New Mexico, Oklahoma, South Dakota, Texas, and Wyoming. To provide assistance, technical support, and additional information, contracts were awarded to the Kansas Geological Survey, New Mexico Natural Resources Department, Oklahoma Water Resources Board, and Texas Department of Natural Resources. In addition, valuable information was provided by many other State and local agencies throughout the High Plains. Their contributions are an integral part of this investigation without which this report would not have been possible.

The U.S. Geological Survey coordinated its investigation of the High Plains aquifer with a concurrent study by the Economic Development Administration of the Department of Commerce. The Six-State High Plains-Ogallala Aquifer Area study conducted by the Economic Development Administration was authorized by Congress in 1976. This study was charged with the responsibility of examining the feasibility of increasing water supplies to insure the economic growth and vitality of the High Plains. Together, these two studies will provide a comprehensive evaluation of the High Plains aquifer and the potential impacts of declining ground-water supplies on the region. The Economic Development Administration study will develop and propose alternative strategies to alleviate or mitigate those impacts and the U.S. Geological Survey will provide hydrologic data and models needed to evaluate the effects of those strategies on the ground-water resource. 


\section{CONVERSION FACTORS}

The following report uses inch-pound units as the primary system of measurements and metric units for water chemistry measurements. The units commonly are abbreviated using the notations shown below in parentheses. Inchpound units can be converted to metric units by multiplying by the factors given in the following list.

\begin{tabular}{lll}
\hline \multicolumn{1}{c}{ Inch-pound unit } & Multiply By & To obtain metric units \\
\hline inch & $2.54 \times 10^{1}$ & millimeter \\
foot & $3.048 \times 10^{-1}$ & meter \\
mile & 1.609 & kilometer \\
square foot $\left(\mathrm{ft}^{2}\right)$ & $9.29 \times 10^{-2}$ & square meter \\
acre & $4.047 \times 10^{-1}$ & hectare \\
square mile $\left(\mathrm{mi}^{2}\right)$ & 2.59 & square kilometer \\
acre-foot $(\mathrm{acre}-\mathrm{ft})$ & $1.233 \times 10^{-3}$ & cubic hectometer \\
foot per day $(\mathrm{ft} / \mathrm{d})$ & $3.048 \times 10^{-1}$ & meter per day \\
cubic foot per second $(\mathrm{ft} / \mathrm{s})$ & $2.832 \times 10^{-2}$ & cubic meter per second \\
gallon per minute $(\mathrm{gal} / \mathrm{min})$ & $6.308 \times 10^{-2}$ & liter per second \\
ton & $9.072 \times 10^{-1}$ & megagram \\
\hline
\end{tabular}




\section{CONTENTS}

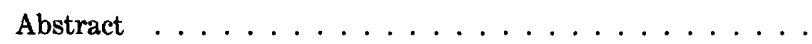

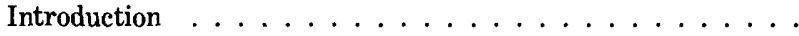

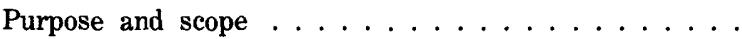

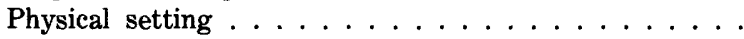

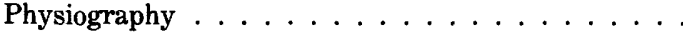

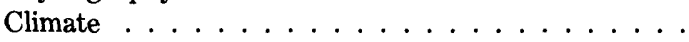

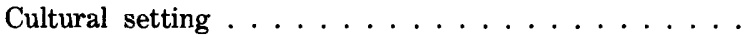

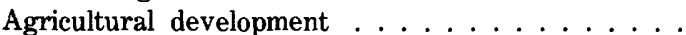

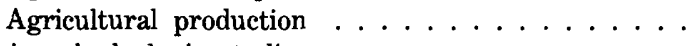

Previous hydrologic studies .............

Geology . . . . . . . . . . . . . . . .

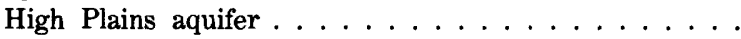

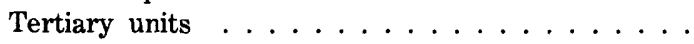

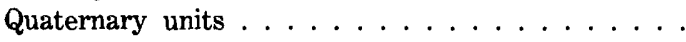

Depositional history .............

Bedrock

Permian units

Triassic and Jurassic units .............

Cretaceous units

\begin{tabular}{|c|c|c|}
\hline ge & & Page \\
\hline 1 & Geology-Continued & \\
\hline 2 & Bedrock-Continued & \\
\hline 2 & Tertiary units & 16 \\
\hline 2 & Relationship between bedrock and aquifer $\ldots \ldots \ldots$ & 16 \\
\hline 2 & Faults $\ldots \ldots \ldots \ldots \ldots \ldots$ & 16 \\
\hline 3 & Salt dissolution $\ldots \ldots \ldots \ldots \ldots \ldots \ldots$ & 17 \\
\hline 3 & Ground-water hydrology $\ldots \ldots \ldots \ldots \ldots$ & 17 \\
\hline 3 & $\ldots \ldots \ldots$ & 17 \\
\hline 7 & $\ldots \ldots \ldots \ldots$ & 20 \\
\hline 7 & $\ldots \ldots \ldots \ldots$ & 23 \\
\hline 7 & $\ldots \ldots \ldots \ldots$ & 26 \\
\hline 8 & $\ldots \ldots \ldots \ldots$ & 34 \\
\hline 8 & $\ldots \ldots \ldots$ & 34 \\
\hline 11 & $\ldots \ldots \ldots$ & 38 \\
\hline 1 & Ground-water development & 40 \\
\hline 1 & Irrigation development & 40 \\
\hline 1 & $\ldots \ldots \ldots \ldots$ & 45 \\
\hline 1 & evelopment . . . . . . . . . . & 47 \\
\hline 15 & 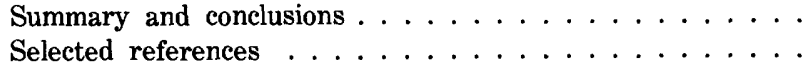 & \\
\hline
\end{tabular}

\section{ILLUSTRATIONS}

\section{Figures 1-4. Maps showing:}

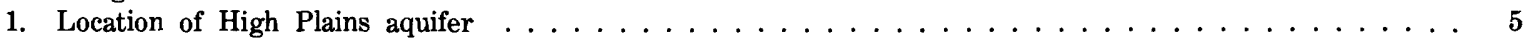

2. Normal annual precipitation and Class $A$ pan evaporation in the High Plains $\ldots \ldots \ldots \ldots \ldots$

3. Principal geologic units in the High Plains aquifer .................... 10

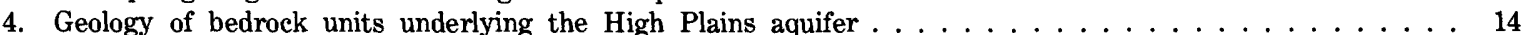

5. Graph showing area of High Plains aquifer in contact with bedrock units . . . . . . . . . . . . . 15

6. Map showing altitude of base of the High Plains aquifer $\ldots \ldots \ldots \ldots \ldots$

7. Diagram showing geohydrologic sections through the High Plains aquifer . . . . . . . . . . . . . . 19

8-15. Maps showing:

8. Water table in the High Plains aquifer, $1980 \ldots \ldots \ldots \ldots \ldots \ldots \ldots \ldots \ldots$

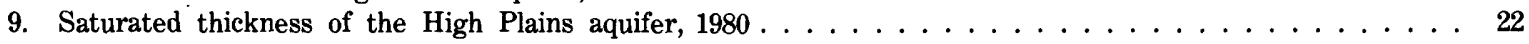

10. Areal distribution of hydraulic conductivity in the High Plains aquifer . . . . . . . . . . . 25

11. Areal distribution of specific yield in the High Plains aquifer . . . . . . . . . . . . . . . . 27

12. Predevelopment water table and direction of ground-water flow in the High Plains aquifer ....... 29

13. Discharge in the Platte River drainage, 1975 water year . . . . . . . . . . . . . . . . 30

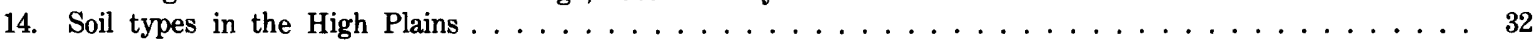

15. Dissolved-solids concentration in water from the High Plains aquifer . . . . . . . . . . . . . 35

16. Graph showing percentage volume of water in the High Plains aquifer exceeding indicated concentration of dissolved solids $\ldots \ldots \ldots \ldots \ldots \ldots \ldots \ldots \ldots \ldots \ldots \ldots$

17-20. Maps showing:

17. Sodium concentration in water from the High Plains aquifer $\ldots \ldots \ldots \ldots \ldots$

18. Density of acreage irrigated by ground water in the High Plains, $1949 \ldots \ldots \ldots \ldots \ldots$

19. Density of acreage irrigated by ground water in the High Plains, $1964 \ldots \ldots \ldots \ldots$

20. Density of acreage irrigated by ground water in the High Plains, $1978 \ldots \ldots \ldots \ldots$

21. Graph showing acreage irrigated by ground water in the High Plains, 1949-78 . . . . . . . . . . . . . . 44

22. Graph showing estimated ground-water pumpage from the High Plains aquifer, 1949-78 . . . . . . . . . . . 44

23. Map showing predevelopment to 1980 water-level changes in the High Plains aquifer . . . . . . . . . . . . . 46

24. Map showing potential well yields from the High Plains aquifer, $1980 \ldots \ldots \ldots \ldots$

25. Diagram for classification of salinity and sodium hazards for irrigation water . . . . . . . . . . . . . 50

26. Map showing generalized depth to water in the High Plains aquifer, $1980 \ldots \ldots \ldots$

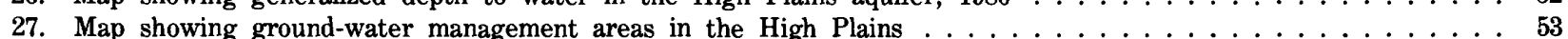




\section{TABLES}

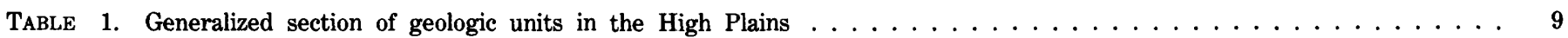

2. Distribution and volume of saturated material, High Plains aquifer, $1980 \ldots \ldots \ldots$

3. Statistics on the vertical distribution of transmissivity and storage depth in the High Plains aquifer . . . . . . 24

4. Distribution of average hydraulic conductivity in the High Plains aquifer . . . . . . . . . . . . 26

5. Hydraulic-conductivity and specific-yield values assigned to lithologic descriptions of the High Plains aquifer . . . . 26

6. Distribution of average specific yield in the High Plains aquifer $\ldots \ldots \ldots \ldots$

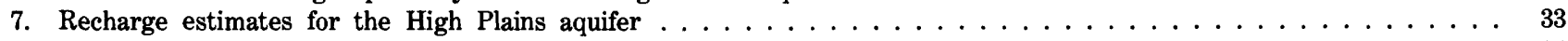

8. Distribution of drainable water in storage in the High Plains aquifer, $1980 \ldots \ldots \ldots$

9. Chemical analyses of selected water samples from the High Plains aquifer . . . . . . . . . . . . . . . 36

10. Chemical data from selected water samples from the High Plains aquifer . . . . . . . . . . . . . . . . 38

11. Distribution of water-level changes and volume of aquifer dewatered, High Plains aquifer, predevelopment to 1980.47

12. Summary of regulations controlling ground-water development from the High Plains aquifer, by State . . . . . . . 54 


\title{
GEOHYDROLOGY OF THE HIGH PLAINS AQUIFER IN PARTS OF COLORADO, KANSAS, NEBRASKA, NEW MEXICO, OKLAHOMA, SOUTH DAKOTA, TEXAS, AND WYOMING
}

\author{
By Edwin D. GutentaG, Frederick J. Heimes, Noel C. Krothe, Richard R. Luckey, and \\ JOHN B. WEEKS
}

\begin{abstract}
The High Plains aquifer, which underlies about 174,000 square miles in parts of eight States, is the principal source of water in one of the Nation's major agricultural areas. About 170,000 wells pump water from the aquifer to irrigate about 13 million acres in the High Plains. In 1978, the U.S. Geological Survey began a regional study of the High Plains aquifer to provide geohydrologic data and computer models of the aquifer needed to evaluate the effects of ground-water development. This report describes the geohydrology of the High Plains aquifer.

The High Plains aquifer consists mainly of hydraulically connected geologic units of late Tertiary or Quaternary age. The upper Tertiary rocks include part of the Brule Formation, Arikaree Group, and Ogallala Formation. The Quaternary deposits included in the aquifer consist of alluvial, dune-sand, and valley-fill deposits.

The Ogallala Formation, which underlies 134,000 square miles, is the principal geologic unit in the High Plains aquifer. The Ogallala consists of a heterogeneous sequence of clays, silts, sands, and gravels deposited by streams that flowed eastward from the mountains. Within the Ogallala, zones cemented with calcium carbonate are resistant to weathering and form escarpments that typically mark the boundary of the High Plains.

The High Plains aquifer is, regionally, a water-table aquifer consisting mostly of near-surface sand and gravel deposits. The maximum saturated thickness of the aquifer is about 1,000 feet and averages 200 feet. Hydraulic conductivity and specific yield of the aquifer depend on sediment types, which vary widely both horizontally and vertically. Consequently, hydraulic conductivity and specific yield also are highly variable. Hydraulic conductivity ranges from less than 25 to 300 feet per day and averages 60 feet per day. Specific yield ranges from less than 10 to 30 percent and averages about 15 percent.

Ground-water flow generally is from west to east, at an average rate of about 1 foot per day, and discharges naturally to streams and springs, and directly to the atmosphere by evapotranspiration. Precipitation is the principal source of recharge to the High Plains aquifer. Estimated recharge rates range from 0.024 inch per year in part of Texas to 6 inches per year in south-central Kansas. Typically, recharge estimates are greatest for sandy soils.

The High Plains aquifer contains about 3.25 billion acre-feet of drainable water. About 66 percent of the water in storage is in Nebraska and about 12 percent is in Texas. New Mexico, the State with the smallest water resource in the High Plains, has only 1.5 percent of the volume of water in storage.
\end{abstract}

The quality of water in the High Plains aquifer generally is suitable for irrigation use but, in many places, the water does not meet U.S. Environmental Protection Agency drinking-water regulations. Excessive concentrations of dissolved solids, fluoride, chloride, and sulfate occur in parts of the aquifer in all States.

About 62 percent of the area of the High Plains aquifer contains water with 250 to 500 milligrams per liter dissolved solids; only 3 percent of the area of the aquifer contains water exceeding 1,000 milligrams per liter dissolved solids, most of which is in Texas. Generally, dissolved-solids concentrations are least in areas covered by sand because recharge is relatively large and the sand contains few readily soluble minerals. In most areas of the High Plains aquifer where the concentration of dissolved solids exceeds 1,000 milligrams per liter, the chemical composition of the water is affected by the underlying bedrock.

Sodium concentrations in ground water from the aquifer generally are less than 100 milligrams per liter. About 56 percent of the area of the aquifer contains water with less than 25 milligrams per liter sodium; only 3 percent of the area contains water exceeding 100 milligrams per liter sodium, most of which is in Texas. The concentration of sodium varies in response to the same factors that affect the concentration of dissolved solids. In parts of the southern High Plains of Texas, anomalously large concentrations of dissolved solids and sodium, caused by surface disposal of oilfield brines, have been reported.

About 95 percent of all water pumped from the High Plains aquifer is used for irrigation. In 1978, the reported number of acres irrigated in the High Plains was 13 million and about 170,000 wells pumped an estimated 23 million acre-feet of water for irrigation.

In parts of the High Plains, annual pumpage of 2 to 100 times greater than annual recharge has caused large water-level declines. Water levels have declined more than 100 feet from predevelopment to 1980 in parts of Kansas, New Mexico, Oklahoma, and Texas in areas totaling 2,500 square miles. Water levels have declined more than 50 feet in areas totaling 12,000 square miles and more than 10 feet in areas totaling 50,000 square miles. Water-level declines increase pumping lift, decrease well yields, and limit development of the ground-water resource.

The volume of water in storage in the aquifer has decreased about 166 million acre-feet since ground-water development began. Most of the depletion has occurred in Kansas and Texas: about 114 million acre-feet of depletion in Texas and 29 million acre-feet of depletion in Kansas.

The chemical quality of water in the aquifer may limit irrigation development in some areas. Areas of high salinity hazard occur in 
Colorado, Kansas, Oklahoma, New Mexico, Texas, and Wyoming. In these areas, water from the High Plains aquifer may not be suitable for irrigation on soils that are not well drained.

The depth to water below land surface affects the cost of pumping water for irrigation. Declining water levels and increasing energy costs may seriously impact the economics of future irrigation development. The depth to water in the High Plains aquifer already is greater than 300 feet in parts of Kansas, New Mexico, and Texas.

Legal constraints also control development of ground water. The regulations controlling ground-water development vary widely between States and within some States. Future development of the High Plains aquifer will continue to be controlled by the laws of the individual States in the High Plains.

\section{INTRODUCTION}

The High Plains aquifer includes about $174,000 \mathrm{mi}^{2}$ (see Conversion Factors for definitions of abbreviated units) of the central United States east of the Rocky Mountains in the southern part of the Great Plains. Parts of Colorado, Kansas, Nebraska, New Mexico, Oklahoma, South Dakota, Texas, and Wyoming are underlain by the High Plains aquifer as shown in figure 1 . Ground water withdrawn from the aquifer is the principal water resource for most of the High Plains region, which is an important agricultural area. The High Plains aquifer is the shallowest and most abundant source of ground water in the region and the irrigated agricultural economy is dependent on the aquifer for continued growth and prosperity.

However, declining water levels and decreasing water supplies are causing serious concerns about the feasibility of continued crop production using ground water for irrigation. A comprehensive knowledge of the High Plains aquifer system is needed to provide a basis for predicting the effects of continued irrigation development.

\section{PURPOSE AND SCOPE}

National concern about the economic impact of declining water supplies in the High Plains resulted in the beginning of a regional study of the High Plains aquifer in 1978 as one of the first studies within the Regional Aquifer-System Analysis program of the U.S. Geological Survey. The purpose of this program is to provide hydrologic information and analytical capabilities needed for effective management of the Nation's ground-water resources.

The purpose of the High Plains study is to provide: (1) Hydrologic information needed to evaluate the effects of continued ground-water development; and (2) computer models to predict aquifer response to changes in ground-water development. This study is intended to provide managers with a coherent and comprehensive data set needed for ground-water resource man- agement, and a tool (computer model) for evaluation of water-management alternatives. The computer model will be tested using historical data on irrigation demand and development. Selected ground-water management alternatives will be simulated to predict their effectiveness in prolonging the water supply.

A complete description of geology and hydrology of the High Plains aquifer is required for design and development of a computer model of the aquifer system. This report presents the geohydrologic framework on which the model will be based. The geologic and hydrologic characteristics of the aquifer are described; the relationships between the aquifer and bedrock units are discussed; the quantity and quality of ground water are presented; the effects of irrigation development on the aquifer are included.

\section{PHYSICAL SETTING}

The High Plains occupies the southern part of the Great Plains physiographic province which lies between the Rocky Mountains on the west and the Central Lowland on the east. The High Plains extends from southern South Dakota to northwestern Texas. The Platte, Arkansas, and Canadian Rivers are the only streams crossing the High Plains that originate in the Rocky Mountains. The area south of the Canadian River is commonly called the southern High Plains.

\section{PHYSIOGRAPHY}

The High Plains is characterized by flat to gently rolling terrain, which is a remnant of a vast plain formed by sediments that were deposited by streams flowing eastward from the Rocky Mountains. The ancestral plain extended from the mountains eastward beyond the Missouri River in some places (Trimble, 1980b). Regional uplift forced streams to cut downward and erode the plain. Near the mountains, the plain was eroded by the Missouri, Platte, Arkansas, and Pecos Rivers, and the eastern border was eroded by many small streams. Erosion isolated the plains from the mountains and formed escarpments that typically mark the boundary of the High Plains. Only in southeastern Wyoming does the original plain still extend to the mountain front.

Wind-blown sand and silt, derived from the beds of rivers that eroded the plains, were deposited throughout large areas of the High Plains. The largest expanse of wind-blown sand deposits and dune topography in the Western Hemisphere (about $20,000 \mathrm{mi}^{2}$ ) is in $\mathrm{Ne}$ braska (Madson, 1978) between the Platte and Niobrara Rivers. Within these sand hills, lakes and meadows occur between dunes where ground water is at or near land surface. Smaller areas of sand dunes occur in many other parts of the High Plains. 
Many lakes also occur on the High Plains outside of Nebraska. However, these lakes are shallow depressions or playas that collect and store water during periods of runoff; some of the deeper playas hold water throughout the year. Playas are most prevalent south of the Arkansas River. Because playas in the High Plains generally are above the regional water table, the water surfaces in the playas do not reflect the altitude of the water table in the underlying aquifer, as many of the lakes do in the sand hills of Nebraska.

\section{CLIMATE}

For the most part, the High Plains has a middle latitude dry continental climate. The climate is one of abundant sunshine, moderate precipitation (less than 20 inches), frequent winds, low humidity, and a high rate of evaporation. Some areas of the High Plains in central Kansas and eastern Nebraska have a humid continental climate that has higher precipitation and humidity than the dry continental climate.

Mean annual precipitation increases eastward across the High Plains by about 1 inch every 25 miles from less than 16 inches to about 28 inches in eastern Nebraska and central Kansas as shown in figure 2. Typically, about 75 percent of the precipitation falls as rain during the growing season, April through September, a condition favorable to agriculture. However, much of the rain results from local thunderstorms, so large variations in rainfall can occur from place to place and year to year.

Both dry and humid continental climates have large daily and seasonal extremes of temperature. Daily temperatures may vary $15^{\circ}$ to $30^{\circ} \mathrm{C}$ (Celsius). The seasonal extremes of temperature vary about $70^{\circ} \mathrm{C}$ between winter lows and summer highs. Wind direction and speed varies throughout the year, which is a consequence of cyclonic storms. Occasionally during the summer months, hot winds during extended dry periods cause crop damage and discomfort to animals and humans. Winter months generally are colder, dryer, and windier than the areas immediately east of the High Plains. Snowfall normally is light and often is accompanied by high winds with a resultant uneven distribution.

Persistent winds and high summer temperatures cause high rates of evaporation in the High Plains. Mean annual evaporation from Class A pans ranges from about 60 inches in northern Nebraska and southern South Dakota to about 105 inches in western Texas and southeastern New Mexico (fig. 2). Because of the large evaporative demand, little precipitation is available to recharge the ground-water system. Except in sand-dune areas where water can readily percolate down to the water table, most of the water that enters the soil is returned to the atmosphere by evapotranspiration. Recharge to the ground-water system may be several inches per year in sand-dune areas; but, throughout the much larger part of the High Plains where soils can hold the water for subsequent evapotranspiration, recharge may average less than 0.5 inch per year.

Climate is the key factor in soil formation. Soils west of $97^{\circ} \mathrm{W}$. longitude, which formed under short grass, are limy and those soils east of the $97^{\circ} \mathrm{W}$. longitude, which formed under tall grass, are acid (White and Renner, 1957, p. 225). The limy soils are found in the dry continental climate where low precipitation and the absence of leaching account for the excellent fertility of the soil. Because evaporation greatly exceeds precipitation, there is an upward movement of nutrient minerals to the surface. The limy soils are extremely productive when water is available for vegetative growth.

\section{CULTURAL SETTING}

With few trees and little precipitation, the plains were known as the Great American Desert. Prior to the Civil War, the High Plains was home to few except the Plains Indians and North American bison upon which the Indians depended. The Indians dominated the plains until the late 1800's when the transcontinental railroad was constructed and the bison were virtually exterminated. The railroad opened the plains to range cattle. The grassy plains proved to be as favorable for cattle as they had been for bison and the Great American Desert became cattle country.

\section{AGRICULTURAL DEVELOPMENT}

Two pieces of legislation enacted during the Civil War greatly influenced the settling of the plains and the development of agriculture. The Homestead Act of 1862 made the plains part of the public domain where land could be obtained for nominal fees. The Morrill Act of 1862 provided for the establishment of landgrant colleges. In 1863, Kansas State Agricultural College was established in Manhattan, Kansas, near the border of the High Plains.

During the late 1800 's when the Plains Indians were no longer a threat, settlers and speculators began to surge onto the plains. Conflicts between farmers and ranchers resulted in range wars over fencing; but as the numbers of homesteaders grew, farmers were able to demand and defend their rights. During the severe winters of $1886-87,50$ to 60 percent of the range cattle starved (White and Renner, 1957, p. 229). The rangecattle industry never recovered and farming, supported by agricultural colleges, became the dominant industry. 


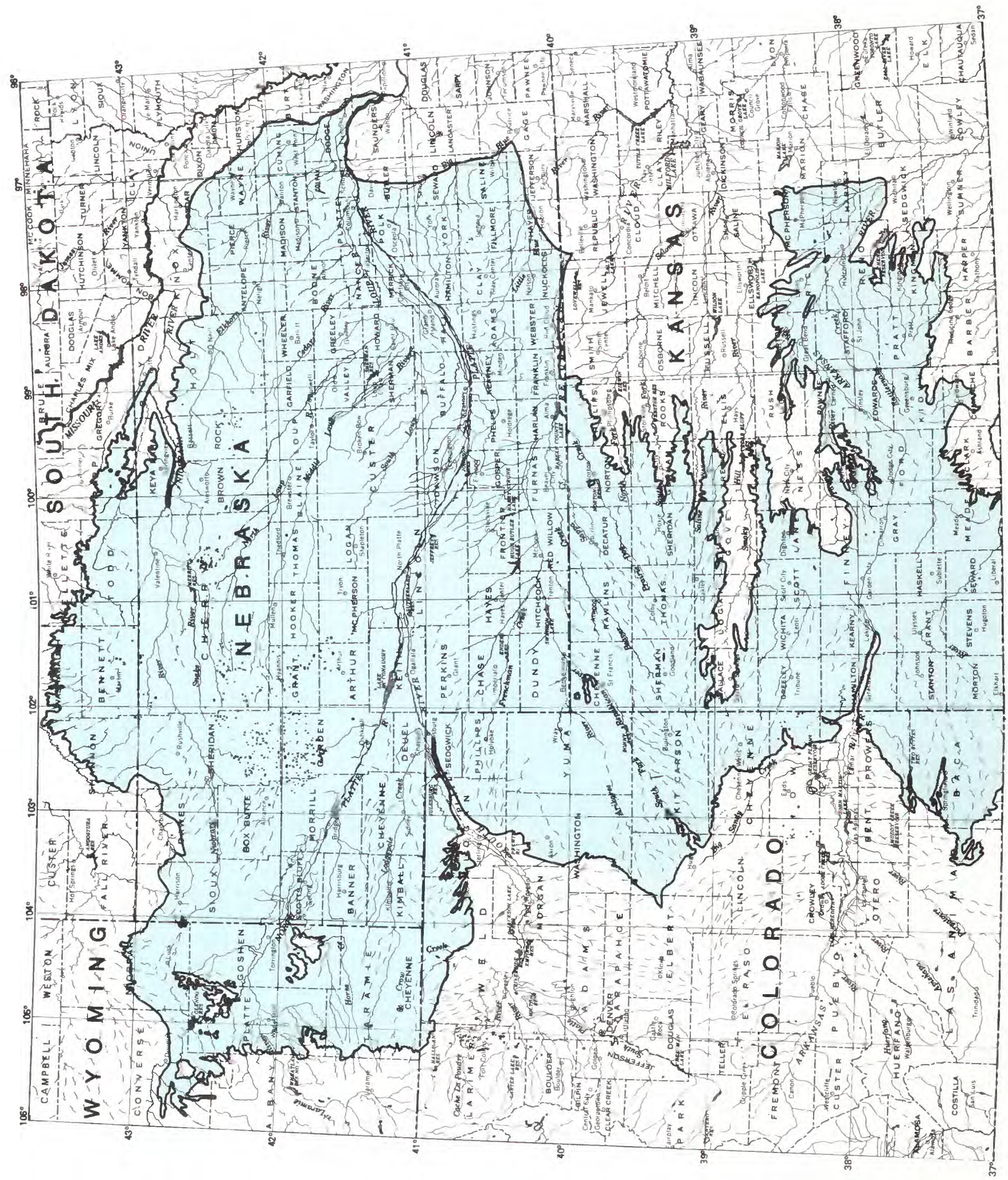




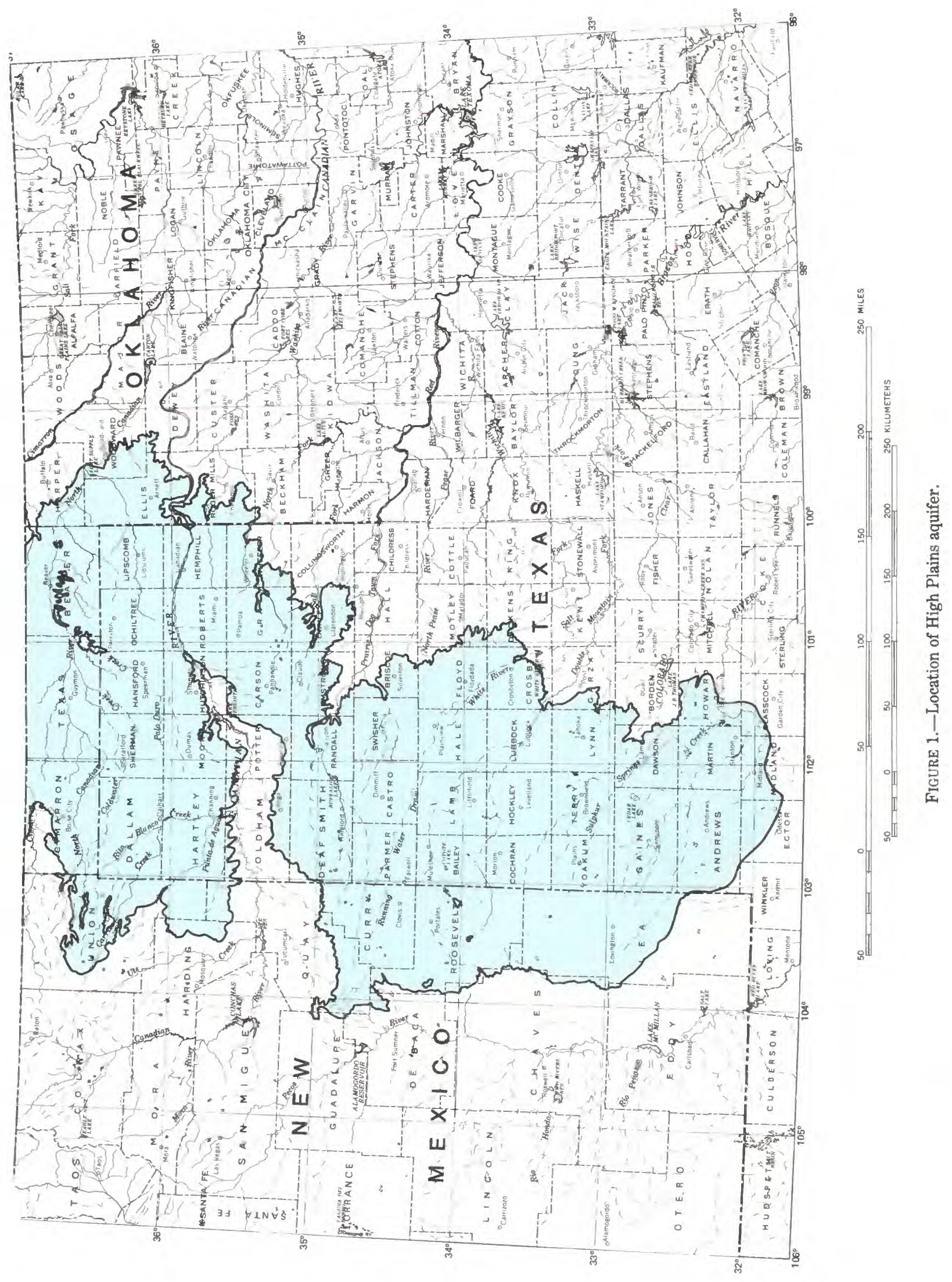




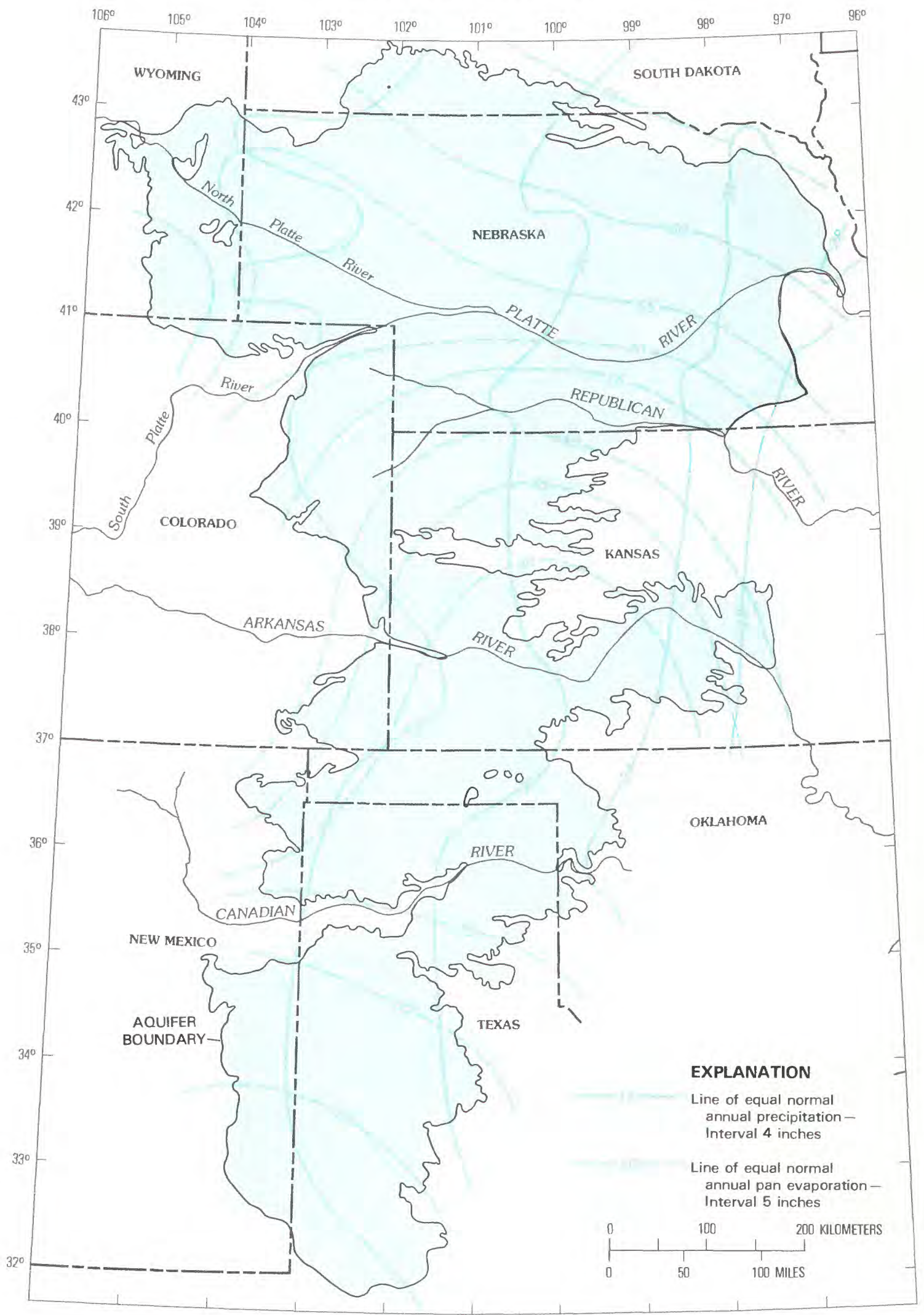

FIGURE 2.-Normal annual precipitation and Class A pan evaporation in the High Plains (modified from U.S. Department of Commerce, 1977). 
From the turn of the century until World War I, agricultural development of the plains increased rapidly. During and after World War I, wheat became the dominant crop as a result of the war effort. The plains were planted to wheat year after year and by the time the drought of the 1930's occurred, continuous cropping had depleted the humus that bound the soil. The resulting poor crops were pastured to livestock and the ground became pulverized (White and Renner, 1957, p. 225). Wind erosion literally blew away the soil in gigantic dust clouds and the High Plains became known as the Dust Bowl. The drought of the 1930's spurred the development of irrigation farming on the High Plains and, during the next 2 decades, irrigation transformed the High Plains from Dust Bowl to Breadbasket-one of the major farming areas in the United States.

\section{AGRICULTURAL PRODUCTION}

Of total United States crop production in 1977, the High Plains produced 16 percent of the wheat, 13 percent of the corn, 40 percent of the sorghum, and 25 percent of the cotton. The total value of crops produced in the High Plains in 1977 was about $\$ 4.6$ billion (High Plains Associates, 1982, p. 9 and 2-2). In addition, the High Plains produces about 40 percent of the feedlot beef raised in the United States. Grubb (1978) reported that, for the High Plains, total cash receipts for irrigated crops was more than $\$ 2$ billion (nearly one-half of the High Plains total) and livestock production was valued at more than $\$ 10$ billion.

During 1978, about 170,000 wells in the High Plains pumped about 23 million acre- $\mathrm{ft}$ of water to irrigate 13 million acres. More than 20 percent of the irrigated land in the United States overlies the High Plains aquifer and about 30 percent of the ground water used for irrigation in the United States was pumped from the High Plains aquifer. Irrigation pumpage has caused areally extensive water-level declines in the aquifer. Consequently, many irrigators have experienced increased pumping costs, decreased well yields, and concern about the future of irrigation farming on the High Plains.

\section{PREVIOUS HYDROLOGIC STUDIES}

The first regional study of the High Plains was conducted by the U.S. Geological Survey at the beginning of this century (Johnson, 1901). The study provided a reconnaissance of the geographic, physiographic, and hydrologic features of the area and reported on the region within the framework of the then current technology. The conclusions of the study pointed to the vast ground-water resources of the area but held little prom- ise for agricultural development of the region because of limited rainfall, high evaporation, and few surface streams.

Since that time, technological advances have provided the means to recover the ground-water resource identified by Johnson (1901). However, hydrologic studies of the region have not kept pace with groundwater development. Many water-resource studies of small areas such as counties or groups of counties have been made, but few studies of larger areas within the High Plains have been made. In fact, only one other region-wide hydrologic study has been made since 1901 and that was reported on by Lohman (1953). The results of previous investigations provide a wealth of information subdivided by political boundaries but without continuity across those boundaries.

The results of previous studies provided the foundation for the Regional Aquifer-System Analysis of the High Plains aquifer. In developing the geohydrologic framework of the High Plains aquifer, this investigation assembled, organized, and assimilated the geohydrologic data available from many previous studies. The principal references (about 180) are listed in the Selected References section of this report.

\section{GEOLOGY}

The geologic history of the High Plains began more than 500 million years ago. During most of Cambrian to Tertiary time (570 to 63 million years ago), shallow seas covered the interior of North America. A thick sequence of sediments, in some places more than 10,000 feet thick, was deposited on the subsiding seafloor.

The sea covered the High Plains almost entirely during the Permian Period ( 290 to 240 million years ago); but it receded during the Triassic Period (240 to 205 million years ago). During Early and Middle Triassic time, the High Plains was subjected to erosion and no depositional record is found between the marine Permian rocks and the continental Upper Triassic rocks. During the Jurassic Period (205 to 138 million years ago), erosion predominated during Early Jurassic time prior to deposition of Middle and Upper Jurassic rocks. Jurassic rocks are of continental origin and represent deposition from intermittent streams during a dry climate. An abundance of fossil remains of dinosaurs and other land animals is characteristic of Jurassic deposits.

Shallow seas covered the area intermittently during Early Cretaceous time (138 to 96 million years ago). In the southern High Plains of Texas, marine shales and sands were deposited in response to changes in sea level. In the northern High Plains, most of the Early Cretaceous rocks were deposited near beaches or in adjoining wet lands, river estuaries, and river valleys. 
During Late Cretaceous time (96 to 63 million years ago), the Rocky Mountain trough formed a vast seaway nearly 1,000 miles wide and 3,000 miles long. As much as 50 percent of present North America was covered by interior seas. The interior seas retreated southward and there was a rapid filling of the basin with sediments from the raising highlands to the west. The final retreat of the sea transformed its old floor into a vast swampy lowland. Eastward-flowing streams deposited thick sediments in this lowland during the closing stages of Cretaceous time. The vegetation that accumulated in the swamps of this lowland formed the vast coal beds of Late Cretaceous age in the Rocky Mountain region from Canada to Mexico.

The Laramide revolution or period of mountain building began about 70 million years ago at about the same time as the great interior sea retreated. The mountains produced by the Laramide revolution rose about onethird as high above sea level as the present-day Rocky Mountains (King, 1959, p. 126). These ancestral Rockies were eroded about as rapidly as they were uplifted. Regional altitudes remained low and the climate was uniformly moist and semitropical. As a result of the Laramide revolution, there was increased availability of water to streams and much rock material was available for stream transport. Mountain building continued into Tertiary time.

The Tertiary Period ( 63 to 2 million years ago) began with a long period of no deposition in most of the High Plains. The oldest Tertiary rocks found on the High Plains are of Oligocene age ( 38 to 24 million years ago). By the middle of the Oligocene, the Rocky Mountains virtually were peneplained, but slight differential uplift that included eastward tilting of the High Plains was occurring locally. During the Oligocene, volcanism was widespread in the mountains (Robinson, 1972) and enormous quantities of volcanic debris and sediment eroded from the mountain blocks were deposited on the plains.

During Miocene time (24 to 5 million years ago), sedimentation on the plains continued with some volcanic material deposited as well as weathered debris from the mountains. Most of the sediments comprising the High Plains aquifer were deposited during this time. Regional uplift was renewed near the end of Miocene time. The Rocky Mountains and the High Plains were raised differentially during this epoch, and uplift of the mountains is still continuing (Izett, 1975). Thus, the erosional cycle that started near the end of Miocene time is the present erosional cycle that has continued to shape the High Plains. By the close of the Miocene, the major physiographic features of the area occupied by the North American grasslands were established (Dix, 1964). The fossil plants and animals contained in the middle and upper Tertiary deposits record increasing regional altitudes and aridity. The transition to more arid conditions resulted partly from world-wide cooling, and partly from the additional uplift of the Rocky Mountains, which produced a rain shadow over the High Plains.

Pliocene time (5 to 2 million years ago) was a period of continued uplift and erosion without much deposition. Regional uplift caused streams to cut downward; near the mountain front, the plains were eroded by the Missouri, Platte, Arkansas, and Pecos Rivers. The High Plains became a remnant of the much larger Miocene plain. Today, the High Plains extends to the mountain front in Wyoming only.

The sculpturing of the High Plains continued through the Quaternary Period ( 2 million years ago to present). Although the High Plains was not eroded by glaciers, stream erosion continued to shape the region. Large quantities of sediment were eroded from the mountains and the plains. Giant braided streams transported large quantities of silt, sand, and gravel and deposited these sediments in stream valleys and terraces. Winds winnowed sand and silt from the stream valleys and redeposited it as dune sand and loess over large parts of the High Plains.

\section{HIGH PLAINS AQUIFER}

The High Plains aquifer consists mainly of one or more hydraulically connected geologic units of late Tertiary or Quaternary age. The principal geologic units in the High Plains aquifer are shown in figure 3 and summarized in the generalized geologic section presented in table 1 . The upper Tertiary rocks consist of the Brule Formation (of the White River Group), Arikaree Group, and Ogallala Formation. The Quaternary deposits consist of alluvial, dune-sand, and valleyfill deposits. Except for dune sand in figure 3, the Quaternary deposits are lumped and are shown only in areas where they do not overlie Tertiary aquifer units. In Texas, some collapse structures, filled with Triassic, Jurassic, and Lower Cretaceous rocks that have secondary permeability, are considered part of the High Plains aquifer, however, they are minor and are not shown in figure 3 .

\section{TERTIARY UNITS}

The Brule Formation crops out in or underlies much of western Nebraska, northeastern Colorado, southwestern South Dakota, and southeastern Wyoming. The Brule is mainly a massive siltstone containing beds of sandstone and channel deposits of sand. Lenticular beds of volcanic ash, claystone, and fine sand are pres- 
TABLE 1.-Generalized section of geologic units in the High Plains [From Weeks and Gutentag, 1981]

\begin{tabular}{|c|c|c|c|c|}
\hline System & Series & Geologic unit & $\begin{array}{c}\text { Thickness, } \\
\text { in feet }\end{array}$ & Physical character \\
\hline \multirow{4}{*}{ 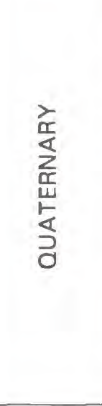 } & \multirow{3}{*}{ 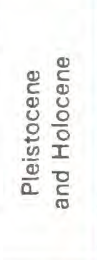 } & $\begin{array}{l}\text { Valley-fill } \\
\text { deposits }\end{array}$ & 0 to 60 & $\begin{array}{l}\text { Stream-laid deposits of gravel, sand, silt, and clay associated with the most recent cycle } \\
\text { of erosion and deposition along present streams. Forms part of High Plains aquifer where } \\
\text { hydraulically connected to underlying Quaternary and Tertiary deposits. }\end{array}$ \\
\hline & & Dune sand & 0 to 300 & $\begin{array}{l}\text { Fine to medium sand with small amounts of clay, silt, and coarse sand formed into hills } \\
\text { and ridges by the wind. Forms part of High Plains aquifer where saturated. }\end{array}$ \\
\hline & & Loess & 0 to 250 & Silt with lesser amounts of very fine sand and clay deposited as windblown dust. \\
\hline & 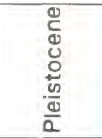 & $\begin{array}{l}\text { Unconsolidated } \\
\text { alluvial deposits }\end{array}$ & 0 to 550 & $\begin{array}{l}\text { Stream-laid deposits of gravel, sand, silt, and clay locally cemented by calcium carbonate } \\
\text { into caliche or mortar beds. Forms part of High Plains aquifer where hydraulically connected } \\
\text { laterally or vertically to Tertiary deposits. }\end{array}$ \\
\hline \multirow{4}{*}{ 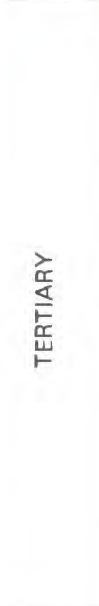 } & \multirow{2}{*}{ 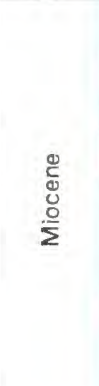 } & $\begin{array}{l}\text { Ogallala } \\
\text { Formation }\end{array}$ & 0 to 700 & $\begin{array}{l}\text { Poorly sorted clay, silt, sand, and gravel generally unconsolidated; forms caliche layers or } \\
\text { mortar beds when cemented by calcium carbonate. Includes units equivalent to the locally } \\
\text { used terms "Ash Hollow," "Kimball," "Sidney Gravel," and "Valentine" Members or } \\
\text { Formations assigned to the Ogallala Formation or "Group," and Delmore and Laverne } \\
\text { Formations. Ogallala comprises large part of High Plains aquifer where saturated. }\end{array}$ \\
\hline & & Arikaree Group & 0 to 1000 & $\begin{array}{l}\text { Predominantly massive very fine to fine-grained sandstone with localized beds of volcanic } \\
\text { ash, silty sand, siltstone, claystone, sandy clay, limestone, marl, and mortar beds. Includes } \\
\text { units assigned to the Hemingford Group of Lugn (1938), Marsland Formation, Rosebud } \\
\text { Formation used in South Dakota by Harksen and Macdonald (1969), and Sheep Creek } \\
\text { Formation. Also includes units equivalent to Gering Formation, Harrison Sandstone, and } \\
\text { Monroe Creek Sandstone. Forms part of the High Plains aquifer. }\end{array}$ \\
\hline & \multirow[b]{2}{*}{ 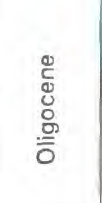 } & \multirow[b]{2}{*}{$\begin{array}{l}\text { White River } \\
\text { Group }\end{array}$} & & \multirow{2}{*}{$\begin{array}{l}\text { Upper unit, Brule Formation, predominantly massive siltstone containing sanustone beds } \\
\text { and channel deposits of sandstone with localized lenticular beds of volcanic ash, claystone, } \\
\text { and fine sand. The Brule Formation is considered part of the High Plains aquifer only where } \\
\text { it contains saturated sandstones or interconnected fractures. Lower unit, Chadron } \\
\text { Formation, mainly consists of varicolored, bentonitic, loosely to moderately cemented clay } \\
\text { and silt that contains channel deposits of sandstone and conglomerate. }\end{array}$} \\
\hline & & & 0 to 700 & \\
\hline \multirow{2}{*}{ 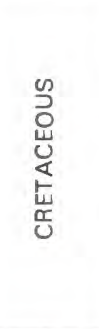 } & 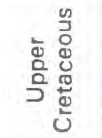 & $\begin{array}{l}\text { Undifferentiated } \\
\text { rocks }\end{array}$ & 0 to 8000 & $\begin{array}{l}\text { Shales, chalks, limestones, and sandstones. Upper part may contain lignite and coal beds. } \\
\text { Unit includes Belle Fourche and Carlile Shales, Codell and Fox Hills Sandstones, Frontier } \\
\text { Formation, Graneros Shale, Greenhorn Limestone, Lance Formation, Niobrara Chalk or } \\
\text { Formation, and Pierre Shale. }\end{array}$ \\
\hline & 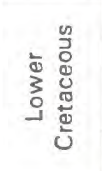 & $\begin{array}{l}\text { Undifferentiated } \\
\text { rocks }\end{array}$ & 0 to 700 & $\begin{array}{l}\text { Fine-to medium-grained, thin-bedded to massive cliff-forming sandstone interbedded with } \\
\text { shale. Black and varicolored shale and thin- to thick-bedded limestone. Includes units } \\
\text { equivalent to Fredericksburg and Washita Groups; Dakota and Purgatoire Formations; Antlers } \\
\text { Sand of Hill (1894), Cheyenne, Fall River, Lakota, Mesa Rica, and Newcastle Sandstones; } \\
\text { and Fuson, Kiowa, Mowry, Skull Creek, and Tucumcari Shales. }\end{array}$ \\
\hline 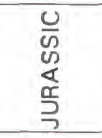 & 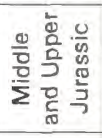 & $\begin{array}{l}\text { Undifferentiated } \\
\text { rocks }\end{array}$ & 0 to 600 & $\begin{array}{l}\text { Varicolored shale, fine- to very coarse grained sandstone, limestone, dolomite, and } \\
\text { conglomerate. Includes units equivalent to Entrada and Exeter Sandstones, and Morrison } \\
\text { and Sundance Formations. }\end{array}$ \\
\hline 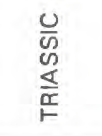 & $\begin{array}{l}\frac{0}{\sqrt{5}} \\
\frac{0}{0} \\
\frac{0}{2}\end{array}$ & $\begin{array}{l}\text { Dockum } \\
\text { Gróup }\end{array}$ & 0 to 2000 & $\begin{array}{l}\text { Upper unit, Trujillo Formation, varicolored siltstone, claystone, conglomerate, fine-grained } \\
\text { sandstone, and limestone. Lower unit, Tecovas Formation, varicolored fine- to medium- } \\
\text { grained sandstone with some claystone and interbedded shale. Include units equivalent to } \\
\text { Chinle and Redondo Formations, and Santa Rosa Sandstone. }\end{array}$ \\
\hline 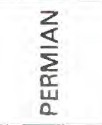 & 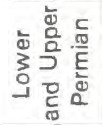 & $\begin{array}{l}\text { Undifferentiated } \\
\text { rocks }\end{array}$ & 300 to 3000 & $\begin{array}{l}\text { Interbedded predominantly red-shale, siltstone, sandstone, gypsum, anhydrite, dolomite, } \\
\text { bedded salt, and local limestone beds. Includes Artesia, Council Grove, Nippewalla Groups; } \\
\text { Quartermaster Formation, Sumner and Whitehorse Groups. }\end{array}$ \\
\hline
\end{tabular}

ent, locally. Maximum thickness of the Brule is about 600 feet.

The Brule Formation generally has little permeability. However, in some places, permeability of the formation has been increased by secondary porosity- joints, fractures, and solution openings. The Brule Formation is considered part of the aquifer only in areas where it contains saturated zones resulting from interconnected secondary porosity (fig. 3). Where secondary porosity has not been developed, the top of the Brule 


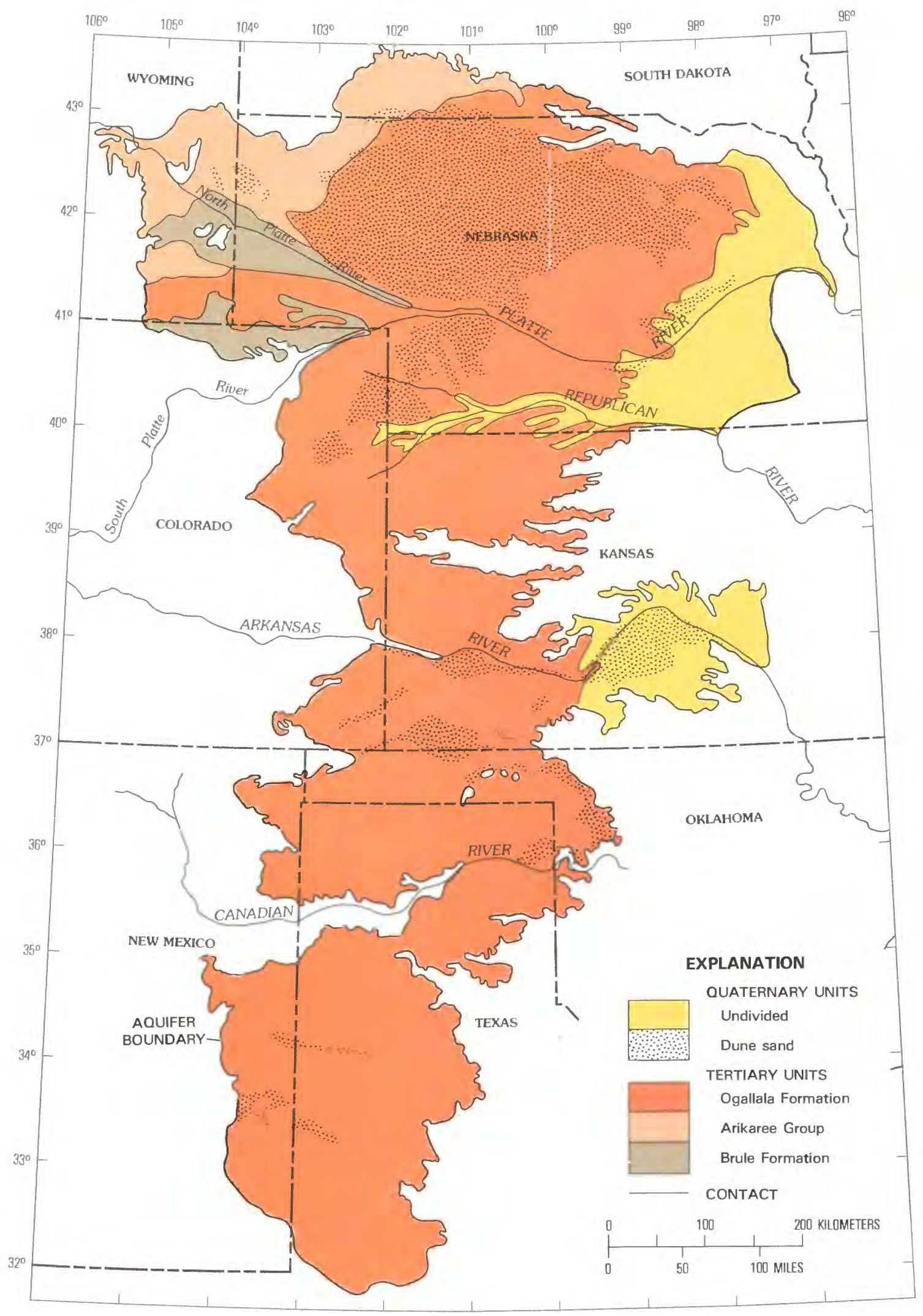

FIgURE 3.-Principal geologic units in the High Plains aquifer. 
Formation is considered the base of the High Plains aquifer. Well yields from the Brule Formation are highly variable because the yield depends on the degree to which secondary porosity has been developed. Wells yielding as much as $1,500 \mathrm{gal} / \mathrm{min}$ from fractured Brule have been reported along Lodgepole Creek in Nebraska and Wyoming and in the vicinity of Julesberg in northeastern Colorado (fig. 1). However, well yields from the Brule Formation typically are less than $300 \mathrm{gal} / \mathrm{min}$.

The Arikaree Group (or Formation) includes all late Tertiary deposits between the underlying Brule Formation and overlying Ogallala Formation. The Arikaree crops out in or underlies large areas in western Nebraska, southwestern South Dakota, and southeastern Wyoming (fig. 3). The Arikaree is mainly a massive, very fine- to fine-grained sandstone, but contains localized beds of volcanic ash, silty sand, and sandy clay. Maximum thickness of the Arikaree is about 1,000 feet in western Nebraska and in Platte County, Wyoming.

Wells completed in the Arikaree Group generally do not yield large quantities of water. In Wyoming and probably western Nebraska, well yields of about 350 $\mathrm{gal} / \mathrm{min}$ can be expected from about 200 feet of saturated thickness. In Niobrara County, Wyoming, yields of $600 \mathrm{gal} / \mathrm{min}$ have been reported from 700 feet of saturated thickness. Secondary porosity, similar to that in the Brule, also occurs in the Arikaree Group.

The term Ogallala Formation, as used in this report, refers to all late Tertiary rocks in the study area that are younger than the Arikaree Group. The Ogallala Formation is the principal geologic unit in the High Plains aquifer and underlies about $134,000 \mathrm{mi}^{2}$ of the study area (fig. 3). Maximum thickness of the Ogallala is about 700 feet. When the Ogallala was deposited, aggrading streams filled and buried valleys eroded into pre-Ogallala rocks. Braided streams flowed eastward from the mountains transporting rock debris, which was deposited as a heterogeneous sequence of clays, silts, sands, and gravels (Fenneman, 1931).

Within the Ogallala, zones cemented with calcium carbonate are resistant to weathering and form ledges in outcrops. The most distinctive of these layers, the Ogallala cap rock (commonly called caliche or mortar bed), is near the top of the Ogallala Formation. The cap rock underlies large areas in Texas and New Mexico, and may be as thick as 60 feet.

Saturated sediments in the Ogallala are not distributed evenly throughout the area. Irrigation wells with yields of about $1,000 \mathrm{gal} / \mathrm{min}$ can be developed from about 100 feet of saturated sand and gravel. In the southern High Plains and in parts of western Kansas, wells pumping $100 \mathrm{gal} / \mathrm{min}$ are developed in areas with as little as 20 feet of saturated sand and gravel.

\section{QUATERNARY UNITS}

Unconsolidated alluvial deposits of Quaternary age that are in hydraulic connection with Tertiary deposits are considered to be part of the High Plains aquifer. Much of the gravel, sand, silt, and clay in the alluvial deposits are reworked from the Ogallala Formation (Gutentag, 1963). These Quaternary alluvial deposits have a maximum thickness of about 300 feet. Alluvial deposits comprise the High Plains aquifer in eastern Nebraska and central Kansas (fig. 3). In many areas of the High Plains, Quaternary alluvial deposits directly overlie the Ogallala Formation to form one aquifer.

Dune-sand deposits of Quaternary age, consisting predominantly of very fine to medium wind-blown sand, are part of the High Plains aquifer. Areas covered by dune sand are shown in figure 3 which was modified from Thorp and others (1952). Of the $174,000 \mathrm{mi}^{2}$ underlain by the High Plains aquifer, about 19 percent is covered by dune sand. The most extensive area of dune sand is in west-central Nebraska where the deposits cover an area of $20,000 \mathrm{mi}^{2}$ with a maximum thickness of about 300 feet. Large areas also are covered by dune-sand deposits south of the Arkansas River in Kansas. In south-central Kansas, dune sand is saturated in many places and forms part of the aquifer system. In southwestern Kansas, the water table generally is below the dune-sand deposits. Throughout the High Plains, dune sands are important recharge areas for the aquifer.

Valley-fill deposits consist of unconsolidated gravel, sand, silt, and clay associated with the most recent cycle of erosion and deposition along present streams. These deposits are as much as 60 feet thick. Valley-fill deposits that are connected hydraulically to underlying Tertiary or Quaternary deposits are considered part of the High Plains aquifer. The valley-fill deposits and associated streams form stream-aquifer systems that link the High Plains aquifer to surface streams, particularly along the Platte, Republican, and Arkansas Rivers.

\section{DEPOSITIONAL HISTORY}

The depositional history of the geologic units that comprise the High Plains aquifer is complex. Both fluvial (stream-deposited) and eolian (wind-blown) sediments form the High Plains aquifer. Most studies of the depositional history of the High Plains aquifer are concerned with the Ogallala Formation. Consequently, the following discussion emphasizes the Ogallala, which is the principal geologic unit in the aquifer (fig 3).

The earliest hypothesis by the U.S. Geological Survey on the mode of deposition of the Ogallala was made by King (1878) who proposed that the Ogallala was deposited in a lake environment. Gilbert (1896) developed 
the theory of stream deposition for the Ogallala and Johnson (1901), in the first regional study of the High Plains, described the Ogallala as a debris apron formed by coalescence of alluvial fans in series along the mountain front. Frye (1970) considered the Ogallala to be deposited by streams with local eolian deposition. Frye also considered the basal part of the formation to be deposited in east-west trending valleys, each containing its own alluvial fill. Coalescence of the alluvial fills from one valley to another took place as the individual divides were buried as the Ogallala deposits thickened. The Ogallala was succinctly described by Schultz (1977, p. 12) as " $* * *$ characterized to a great extent by a monotonous lithology representing a random intermixture of channel and flood-plain environments of deposition."

All theories since Gilbert (1896) on deposition of the Ogallala involve transport to the plains of debris eroded from the mountains by streams. Ore $(1963$, p. 153) studied the Ogallala in Wyoming and found it to be deposited by a rapid aggradational stream where no evidence of a major channel system was noted. He considered the Ogallala to be a sheet deposit laid down by braided streams along a rapidly rising mountain front. Streams that flow away from the mountain front with high discharges will develop braiding when the gradient decreases and deposition takes place.

An important study concerning the vertical and horizontal dimensions of stream deposits that formed the Ogallala was made by Breyer (1975). Breyer applied a statistical approach using Markov chain analysis to detect repetitive lithologic sequences in the Ogallala in Nebraska. The analytical method was to classify the lithology in a vertical sequence into eight facies and tabulate the number of vertical transitions between each of the facies. The eight facies were limestone, marl, clay, silt, sandy silt, sand, gravelly sand, and gravel. The probability of occurrence of each transition was calculated and statistically tested to determine which transitions occurred with greater than random frequency. Breyer found only 4 of the possible 56 facies transitions occurred with greater than random frequencies; these were limestone to sand, clay to sand, gravelly sand to gravel, and gravel to gravelly sand. Breyer $(1975$, p. 4) concluded that the distribution of sediment types (facies) in a vertical section is largely random and representative of deposition by braided streams. Braided stream deposits show coarsening-upward transitions as well as fining-upward transitions.

The Oligocene fluvial deposits of the White River Group were compared by Blodgett (1974) to the modern Platte River system in Nebraska. Blodgett viewed 31 sites in Wyoming and $\mathbf{1 5}$ sites in Nebraska where the fluvial White River deposits were exposed. He con- cluded that fining-upward sequences were present with coarsening-upward sequences. His conclusion was that, in the White River Group, fluvial facies were deposited by aggradational Platte-type braided streams.

Numerous studies of modern braided streams have been made. Kessler (1971) studied braided streams with examples from the South Canadian River, Texas. Waechter (1972) studied the Prairie Dog Town Fork of the Red River in Texas. The Platte River has been studied intensely by Smith (1970), Williams (1978), Blodgett and Stanley (1980), and Crowley (1981). Miall (1977) reviewed the environments of braided streams and showed that vertical sequences recorded in modern and ancient deposits are of several types: channel-fill deposits, valley-fill deposits, channel reoccupation deposits, and point-bar deposits. The identifying feature of braided stream deposits is the occurrence of coarsening-upward as well as fining-upward sediments. There is sufficient evidence from modern streams and ancient stream deposits to indicate that braiding was an important factor in deposition of the High Plains aquifer.

In western Texas and eastern New Mexico, Seni (1980) considered the three-dimensional patterns of Ogallala thickness, sand-body geometry, and formational texture to be consistent with a wet alluvial-fan depositional model. Wet or humid alluvial fans may be regarded as deposits of braided streams that develop without lateral confinement (Reineck and Singh, 1980). The fan facies recognized are the medial and distal facies of alluvial fans. Medial-fan facies are characterized as a broad sand and gravel sheet deposited by braided streams. Medial-fan facies grade downdip into distal-fan facies. Distal-fan facies are characterized by digitate bifurcating sand and gravel bands. Seni (1980) indicated that distal-fan facies are separated by thinner sand and gravel deposits as well as fine-grained material similar to interchannel deposits found on flood plains of meandering streams.

The mode of fluvial deposition depends on the climate at the time the sediments were deposited. Climate can be inferred by determining the ecological factors controlling the flora and fauna that existed during deposition. The climate of the area during late Tertiary time was not the same as the modern climate. The climate at the time the Ogallala was deposited was described by Hibbard (1960) after considering all available fossil faunas and floras as " *** the majority of the area from South Dakota to Texas was a moist, subhumid, subtropical savanna with forests and tall grasses along the river valleys, with chiefly shrubs and tall grasses on the valley walls and on the low divides. Some short grasses may have occurred on the higher and welldrained divides."

The Kilgore flora found in the lower part of the Ogal- 
lala in western Nebraska was compared by MacGinitie (1962) to modern areas where similar flora flourish. The present areas with flora comparable to the ancient Ogallala Kilgore flora are the Kerrville-San Antonio area in south-central Texas and the hills near Monterrey, Mexico. The present climate at San Antonio is considerably wetter and warmer than western Nebraska. Average annual precipitation is about 6 inches greater, average January temperature is about $17^{\circ} \mathrm{C}$ warmer, the average July temperature is about $6^{\circ} \mathrm{C}$ warmer, and the average annual temperature is $11^{\circ} \mathrm{C}$ warmer in San Antonio than in western Nebraska. Thus, the climate of the High Plains during late Tertiary time was wetter and warmer than the present climate, which is consistant with the formation of humid alluvial fans deposited by braided streams.

There is agreement by various investigators that the Ogallala Formation and other geologic components of the High Plains aquifer were deposited by fluvial action. The concept of a humid alluvial-fan model (Seni, 1980) with deposition of the fan material by braided streams is not appreciably different from that of Breyer (1975) who postulated deposition by braided streams. The concept of stream alluviation without fan development and local eolian deposition proposed by Frye (1970) is not contradictory to humid-fan development because in some areas fan development may not have been as active and stream alluviation could have occurred downstream from distal-fan development. Undoubtedly, more than one mode of stream deposition occurred in the vast area of the High Plains.

During Tertiary time, the major mode of deposition was fluvial with minor periods of local eolian deposition. However, during Quaternary time, as the climate of the area became dryer and colder due to mountain uplift, the major mode of deposition in the High Plains changed to eolian.

All areas of the High Plains surface were modified by either erosional or depositional wind action during the Quaternary. The source areas for the eolian deposits were the Tertiary outcrops and the flood-plain deposits of the major rivers. Winds transported fine material eroded from the source areas many hundreds of miles before it was deposited. Different size materials in eolian deposits are separated from each other in the direction of wind movement. Sand will not be carried into the main region of dust deposition. There are transition zones where loess and sand interface with one another. Loess is the dust deposited by ancient dust storms.

Recent dust storms resulted from abnormally low precipitation for prolonged periods. Droughts were common in the middle 1930 's, 1950 's and in the 1970's. Lugn (1962) reported that the March 20th, 1935, dust storm deposited 5 grams of dust per square foot at Lincoln, Nebraska. Dust storms were so severe during the 1930 's that many domestic animals died by suffocation and both man and beast severely suffered from respiratory ailments. Fossil evidence indicates that during late Pleistocene time ( 30,000 to 10,000 years ago) there were many periods when blowing dust adversely affected the mammal population (Schultz, 1968). Some mammals, such as the great mammoths, died from lack of food and water, and their bones were buried by the dust. Later mammal generations returned to repopulate the loess areas when climatic conditions again became favorable and there was available water and forage.

The winds that winnowed dust-sized particles also moved sand-sized material from the source areas to form dune deposits. Dune-sand deposits of Quaternary age consist predominantly of very fine to medium windblown sand. In Nebraska, the largest and most prominant dunes were formed during a time of strong, persistent, and widespread wind action under desert conditions when vegetation was almost absent. At the time the dunes were forming, the landscape was probably similar to that of modern deserts in Africa and Asia (Smith, 1965). At any given place, dune-building winds may be assumed to be at right angles to the average trend of the dune ridges. In Nebraska, the principal wind direction was from the north and northwest based on dune orientation (Ahlbrandt and Fryberger, 1980). Dune development was terminated by climatic change that allowed vegetation to stabilize the dune surface. Many cycles of dune development and stabilization, which resulted from climatic changes during glacial and interglacial periods, are found in the dune sand.

\section{BEDROCK}

Bedrock units in contact with the High Plains aquifer range in age from Permian to Tertiary. The location of the bedrock is shown in figure 4, which is reproduced here from a larger map presented by Weeks and Gutentag (1981). The geology of the bedrock units is summarized in table 1. The area of the High Plains aquifer in contact with each bedrock unit is summarized in figure 5.

\section{PERMIAN UNITS}

The oldest rocks in contact with the High Plains aquifer are of Permian age (290 to 240 million years ago). Permian rocks directly underlie 12 percent of the High Plains aquifer in Kansas, Oklahoma, and Texas (figs. 4 and 5). Permian red beds and evaporites were deposited in extensive, shallow, brackish to saline seas subject to periodic influxes of marine water. Dissolution 


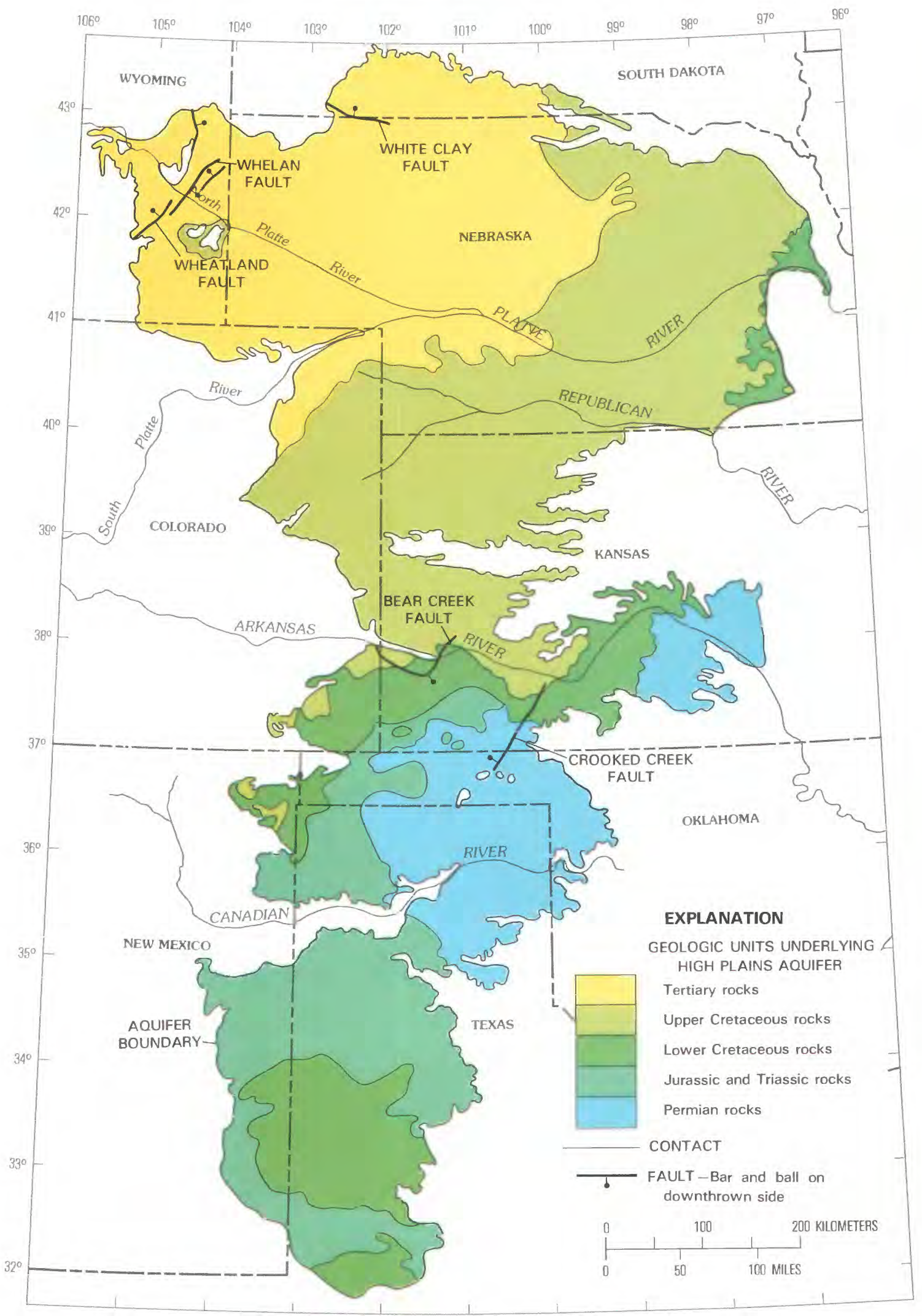

Figure 4.-Geology of bedrock units underlying the High Plains aquifer (from Weeks and Gutentag, 1981). 
and removal of some of these evaporites by ground water within the Permian rocks has resulted in faulting of the overlying deposits (Gutentag, Lobmeyer, and Slagle, 1981). Bear Creek fault (fig. 4) in southwestern Kansas and southeastern Colorado, and Crooked Creek fault (fig. 4) in southwestern Kansas and northwestern Oklahoma, are the result of salt dissolution. Salt collapse basins and a broad zone of salt dissolution in northwestern Texas have been mapped by Seni (1980). Sink holes developed by salt solution subsequently were filled by younger materials that are part of the High Plains aquifer.

Permian rocks in contact with the High Plains aquifer contain water that is not suitable for irrigation use because of large concentrations of dissolved solids. Gutentag, Lobmeyer, and Slagle (1981, p. 39) reported 33,800 $\mathrm{mg} / \mathrm{L}$ (milligrams per liter) dissolved solids in water from a well completed in Permian rocks in Seward County, Kansas. Mineralized water from Permian rock moves naturally through the High Plains aquifer to discharge along the Beaver, Cimarron, and Arkansas Rivers in Kansas and Oklahoma. Generally, Permian rocks have low permeability relative to the overlying High Plains aquifer. Where the High Plains aquifer is in hydraulic connection with Permian beds, water-level declines in the High Plains aquifer can cause or enhance movement of mineralized water from Permian beds into the aquifer.

\section{TRIASSIC AND JURASSIC UNITS}

Rocks of Triassic and Jurassic age (240 to 138 million years ago) directly underlie 16 percent of the High Plains aquifer in Colorado, Kansas, New Mexico, Oklahoma, and Texas (figs. 4 and 5). Although the Triassic and Jurassic are separate systems in table 1 showing the geologic section, they are combined on the geologic map (fig. 4) because the rocks of both systems are predominantly sandstones and shales and have similar hydrologic characteristics.

Lower and Middle Triassic and Lower Jurassic rocks are not present in the High Plains. The missing rocks indicate that continental erosion prevailed through Early and Middle Triassic time prior to deposition of the continental Upper Triassic rocks. Continental erosion again prevailed during Early Jurassic time prior to deposition of Middle and Upper Jurassic rocks.

Some sandstones of Triassic and Jurassic age have adequate permeability to yield large enough quantities of water for irrigation. Between the Arkansas and Canadian Rivers in parts of Colorado, Kansas, Oklahoma, New Mexico, and Texas, many irrigation wells withdraw water from both the High Plains aquifer and Triassic and Jurassic sandstones. In parts of Texas, north of the Canadian River, Triassic and Jurassic sandstones are in direct contact with overlying semiconsolidated sediments of Tertiary age. Locally, where the rocks of both systems are hydraulically connected and are hydrologically similar, the High Plains aquifer includes Triassic and Jurassic sandstones in parts of Dallam, Hartley, Moore, and Sherman Counties, Texas.

\section{CRETACEOUS UNITS}

Lower Cretaceous rocks directly underlie 12 percent of the High Plains aquifer in parts of Colorado, Kansas, Nebraska, New Mexico, Oklahoma, and Texas (figs. 4 and 5). Shallow seas covered the area intermittently throughout Early Cretaceous time (138 to 96 million years ago) when the Lower Cretaceous rocks were deposited. North of the Canadian River, Lower Cretaceous rocks were deposited near sea level or in adjoining lowlands and consist mostly of sandstones and shales. South of the Canadian River, Lower Cretaceous rocks were deposited in deeper water and consist mainly of shales that grade into limestones.

The sandstone beds within the Lower Cretaceous deposits are discontinuous and differ greatly in permeabil-

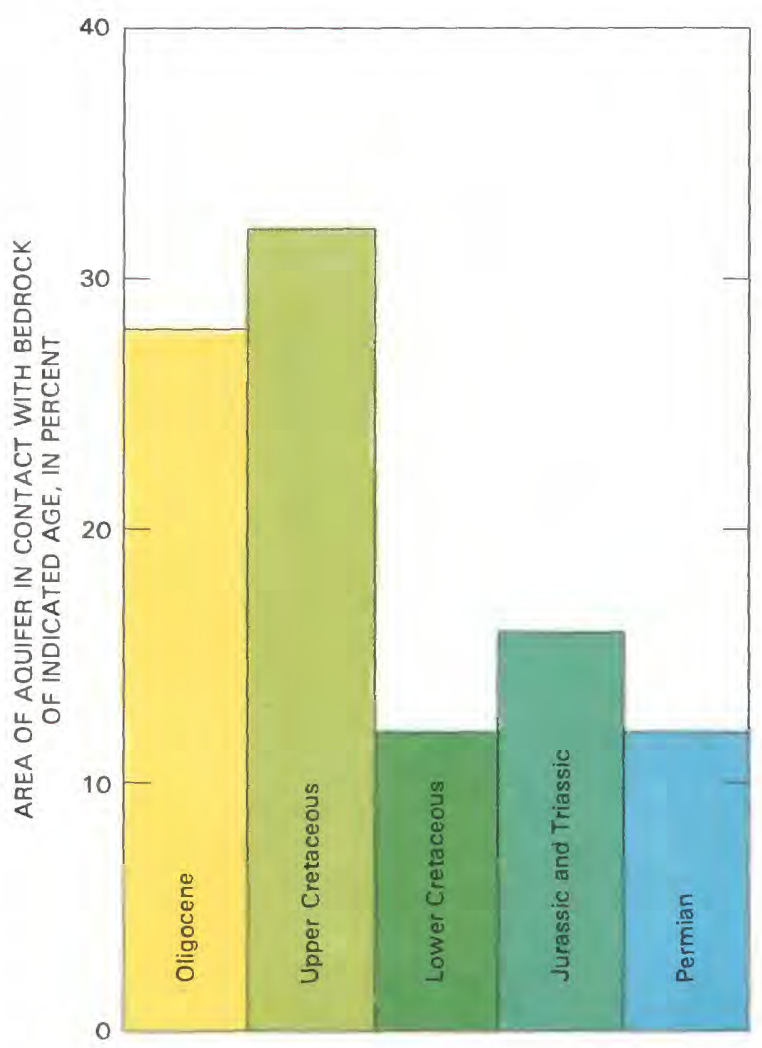

Figure 5.-Area of High Plains aquifer in contact with bedrock units 
ity both horizontally and vertically from one area to another. Where Lower Cretaceous sandstone beds are in contact with the overlying younger deposits in the High Plains aquifer, there is hydraulic connection between the two units. Except in the southern High Plains, Lower Cretaceous sandstones and shales generally contain water of suitable quality for irrigation use. However, these sandstones and shales typically have low permeability and storage relative to the High Plains aquifer and wells completed in Lower Cretaceous rocks experience large drawdowns and well interference throughout large areas.

Upper Cretaceous rocks directly underlie 32 percent of the High Plains aquifer in large areas in Colorado, Kansas, and Nebraska and small areas in New Mexico, South Dakota, and Wyoming (figs. 4 and 5). During Late Cretaceous time (96 to 63 million years ago), Upper Cretaceous shales, chalks, limestones, and sandstones were deposited in the broad Rocky Mountain trough that formed a vast seaway nearly 1,000 miles wide and about 3,000 miles long.

Within the Upper Cretaceous rocks, only the Niobrara Chalk or Formation (table 1) is known to yield water to wells in quantities large enough for irrigation. The Niobrara Chalk underlies the High Plains in Colorado, Kansas, Nebraska, South Dakota, and Wyoming. Where fractures and solution openings have developed, large quantities of water of suitable quality for irrigation have been developed in Finney and Scott Counties, Kansas (Gutentag and Stullken, 1976, p. 11). The water in the Niobrara Chalk in Kansas is derived from the overlying High Plains aquifer. In Madison and Pierce Counties, Nebraska, the Niobrara Chalk yields water to domestic, stock, and municipal wells.

\section{TERTIARY UNITS}

Oligocene rocks directly underlie 28 percent of the High Plains aquifer in Colorado, Nebraska, South Dakota, and Wyoming (figs. 4 and 5). Rocks in the White River Group (38 to 24 million years ago) are the oldest Tertiary deposits present under the High Plains (table 1). Older Tertiary deposits, although present further west, do not underlie the High Plains.

The Chadron and Brule Formations comprise the White River Group. The Chadron Formation is the lower unit and consists of consolidated beds of clay and silt deposited on ancient flood plains and stream channel fill deposits of sandstone and conglomerate. The Chadron is overlain by the Brule Formation, which is predominately a massive siltstone containing consolidated beds of volcanic ash, clay, and fine sand.

The sediments comprising the Brule Formation were deposited in a large basin that contained freshwater lakes, mud flats, and braided streams. The Brule Formation is considered part of the aquifer only in areas where it contains secondary permeability resulting from interconnected fractures (fig. 3). Generally, the top of the Brule Formation is considered the base of the High Plains aquifer.

\section{RELATIONSHIP BETWEEN BEDROCK AND AQUIFER}

Faulting and salt dissolution in the bedrock units affect the base of the High Plains aquifer. The altitude of the base of the High Plains aquifer is shown in figure 6. In this report, National Geodetic Vertical Datum of 1929 is called sea level. Thus, figure 6 shows altitudes relative to modern sea level. The base of the aquifer is primarily an erosional surface cut into Permian, Triassic, Jurassic, Cretaceous, and Tertiary rocks. A larger scale map of the altitude of aquifer base was published by Weeks and Gutentag (1981).

Sandstone beds in Triassic, Jurassic, and Lower Cretaceous rocks are the principal bedrock aquifers underlying the High Plains aquifer. The relationship between the High Plains aquifer and bedrock units is shown by the geohydrologic sections in figure 7 . The north-south section along longitude $102^{\circ} \mathrm{W}$. shows that these bedrock units are in contact with the base of the High Plains aquifer between the Arkansas and Cimarron Rivers and south of the Canadian River. The section along latitude $36^{\circ} 30^{\prime} \mathrm{N}$. shows that these bedrock units also are in contact with the High Plains aquifer west of Beaver River. In the vicinity of the intersection of these two sections, the bedrock units have been uplifted (Irwin and Morton, 1969) and eroded. The erosional surface subsequently was covered by deposits that formed the High Plains aquifer. As a result of this geologic structure, water can move between the High Plains aquifer and bedrock sandstones where they are in contact.

\section{FAULTS}

The present mountain ranges are flanked by upturned sedimentary rocks and in many places by border faults. Faults have little effect on regional groundwater flow in the High Plains aquifer. Locally, faults are important because they affect aquifer thickness and productivity. The Wheatland and Whelan fault systems are of particular significance to the High Plains aquifer in Wyoming (fig. 4). According to Morris and Babcock (1960), the Wheatland and Whelan faults were formed by post-Miocene stresses along faults that were active during the Laramide revolution. The configuration of the bedrock surface has been altered greatly by the 
faults. Along the Wheatland fault, the bedrock has been displaced about 1,000 feet (fig. 6) and much of the Tertiary fill material on the down-thrown side is part of the High Plains aquifer. Faulting took place after deposition of the Tertiary bedrock, and sedimentation was probably about equal to the rate of faulting so that little surface expression was evident.

The White Clay fault is near the Nebraska-South Dakota State line. This normal fault occurred in at least two stages, the most recent of which occurred in middle Tertiary or later time (Dunham, 1961). Within the study area, as shown by figure 4 , the bedrock on both sides of the fault is Tertiary age; the Arikaree Group is adjacent to the White River Group. Outside of the study area, Upper Cretaceous rocks are adjacent to the White River Group. The White Clay fault has caused about 500 feet of displacement in the aquifer base (fig. 6). The Bear Creek and Crooked Creek faults shown on figure 4 are the result of salt dissolution discussed in the following section.

\section{SALT DISSOLUTION}

There are many evaporite beds in the Permian deposits underlying the High Plains. When geologic conditions are favorable, as when joints or fractures are present, the bedded salt is susceptible to dissolution by ground water. Subsequent collapse and filling of dissolution zones has affected aquifer thickness and the quality of ground water.

From the Arkansas River drainage in central Kansas to the Colorado River drainage in Texas, Permian salt deposits are being dissolved by circulating ground water. Saline water from Permian bedrock flows through the High Plains aquifer and the underlying bedrock to discharge along the Beaver, Cimarron, and Arkansas Rivers in Kansas and Oklahoma and the Canadian, all forks and branches of the Red, Peace, Wichita, Brazos, and Colorado Rivers that drain the High Plains in Texas. Gustavson (1980a, p. 71) estimated that the average annual solute discharge for streams draining the southern High Plains of Texas from 1969 to 1974 was 2.8 million tons of dissolved solids per year of which 66 percent ( 1.85 million tons per year) was salt $(\mathrm{NaCl})$.

Ward (1963) and Johnson (1981) reported on the occurrence of salt plains and salt springs on the eastern edge of the High Plains in Oklahoma and Texas. Numerous salt plains caused by evaporation of saline water from Permian bedrock discharging at land surface occur on tributaries to the Arkansas and Red Rivers. According to Johnson (1981), individual salt plains release brines that contribute 110 to 3,300 tons of salt per day that degrade the water quality in the Arkansas and Red River systems.

Sinkholes, depressions, and other collapse structures resulting from salt dissolution occur in many places. Surface manifestations of subsurface dissolution and collapse occur in Hall County, Texas, where more than 400 sinkholes and undrained depressions have been identified from aerial photographs (Simpkins and others, 1981). Salt dissolution structures occur in southern Kansas, Oklahoma, and northern Texas.

Faulting and collapse structures associated with salt dissolution have formed since Permian time. Active sinkholes exist in the vicinity of Bear Creek and Crooked Creek faults. At land surface where unconsolidated materials are affected by collapse structures, concentric slump cracks and scarps outline areas of depression. Older collapse structures have been filled by younger material. For example, a collapse basin in Carson County, Texas, has been filled by several hundred feet of Ogallala Formation (shown by closed contour in fig. 6). Faults resulting from dissolution of evaporites in Permian deposits and collapse of the overlying rocks occur in Colorado, Kansas, and Oklahoma. Movement along these faults occurs as the edge of the dissolution zone is dissolved slowly by ground-water movement.

The Bear Creek fault crosses the Arkansas River twice in Colorado and Kansas. The Crooked Creek fault extends southward from Kansas into Oklahoma. Collapse along these faults has caused about 200 feet of displacement in the altitude of the aquifer base (fig. 6). Salt dissolution in the vicinity of Crooked Creek fault results in large concentrations of chloride in ground water discharging to the Cimarron and Beaver Rivers. The concentration of chloride increases from 215 to $580 \mathrm{mg} / \mathrm{L}$ in a 5 -mile reach of the Cimarron River near Crooked Creek fault (Gutentag, Lobmeyer, and Slagle, 1981, p. 45).

\section{GROUND-WATER HYDROLOGY}

Primarily, geology and climate control the hydrology of the High Plains aquifer. The following sections of this report describe the hydrology of the aquifer and, where appropriate, relate hydrology to the geologic and climatic characteristics that control the availability and quality of ground water.

\section{AQUIFER SYSTEM}

The High Plains aquifer consists of one or more hydraulically-connected geologic units of late Tertiary or Quaternary age that contain sufficient saturated permeable material to yield significant quantities of water to wells and springs. The aquifer can be conceptualized 


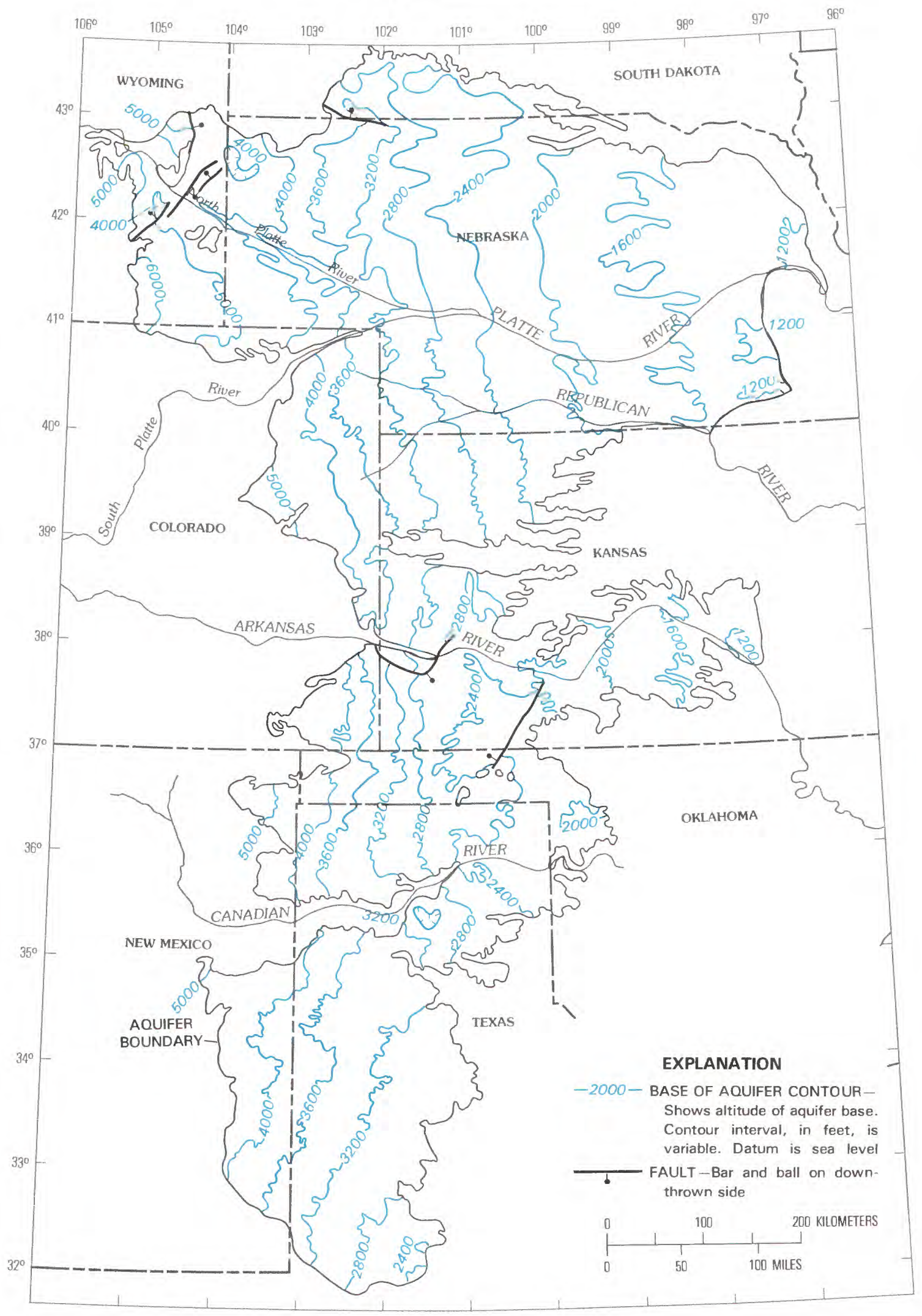

FIgURE 6.-Altitude of base of the High Plains aquifer (modified from Weeks and Gutentag, 1981). 


$$
\text { 王 }
$$


as a three-dimensional subsurface reservoir. The upper surface is the water table, the lower surface is the top of the bedrock, and the sides of the reservoir are the physical limits of the aquifer.

\section{GEOMETRY}

The configuration of the water table in the High Plains depicting the upper surface of the reservoir is shown in figure 8. Water-level data for this map were obtained during the winter and spring of 1980 , when effects of seasonal pumping for irrigation were at a minimum. A larger scale map of the 1978 water table was published by Gutentag and Weeks (1980). There is little difference between the 1978 and 1980 maps because of the contour interval used to depict the water table.

Hydraulic interconnection between geologic units that comprise the High Plains aquifer is sufficient to permit contouring a continuous water table throughout most of the region. The degree of hydraulic interconnection may vary from place to place; and, locally, some water-yielding beds may have a water level representative of a confined pressure surface greater than that of the water table. However, from a regional aspect, water-table conditions prevail in the aquifer.

In a few areas, the aquifer is not saturated and the water table is discontinuous. Wells drilled in these areas will not yield water unless they penetrate saturated sediments in buried channels which were eroded into the bedrock. The major areas where there is little or no saturated aquifer material, are shown on the water-table map (fig. 8). The water table generally slopes eastward across the High Plains, which indicates that the general direction of ground-water flow is eastward.

The configuration of the base of the aquifer is shown in figure 6 which is reduced from a larger scale map by Weeks and Gutentag (1981). Because of the scale of the map, the contours showing the altitude of the base of the aquifer are generalized and only illustrate the principal topographic features of the surface upon which the High Plains aquifer was deposited.

In some areas, data are adequate to define the complex topographic surface of the rocks beneath the High Plains aquifer. In other areas, data are few and the contours are smooth. In areas with smooth contours, an intricately sculptured topographic surface would be revealed if the aquifer materials were stripped away and the surface underlying the aquifer was exposed. The contours illustrate the major predepositional drainage system in the region as well as the effects of faults and salt dissolution of the aquifer base. There is a gen- eral eastward slope of the aquifer base caused by mountain building and regional uplift during the last $70 \mathrm{mil}-$ lion years.

The lateral boundaries of the ground-water reservoir are defined by the physical limits of the geologic units that comprise the aquifer or hydrologic boundaries where discharge occurs. The western boundary of the aquifer is a no-flow boundary because ground water generally flows eastward and escarpments isolate the aquifer from adjacent units except in Wyoming. In Wyoming, the western boundary of the aquifer is a noflow boundary because the adjacent geologic units are relatively impermeable. The eastern boundary of the aquifer is a flow boundary where water from the High Plains aquifer discharges to streams and springs.

The saturated thickness of the aquifer represents the vertical distance between the water table and base of the High Plains aquifer. A saturated-thickness map of the High Plains aquifer was prepared by superimposing 1980 water-table contours over the altitude of the base of aquifer map and constructing lines of equal saturated thickness. The resulting map is presented in figure 9, which shows the 1980 areal variation of saturated thickness. Each thickness interval shows the range in thickness of the aquifer that predominates in that area. Because of map scale, it is not possible to show small areas where saturated thickness may be more or less than that indicated. The 1980 saturated-thickness map was published at a larger scale by Weeks and Gutentag (1981).

Saturated thickness ranges from zero where the deposits comprising the High Plains aquifer are unsaturated to about 1,000 feet in west-central Nebraska. The percentage of the area of the High Plains aquifer within each saturated-thickness interval is summarized by State in table 2. The tabulated results show that 46 percent of the High Plains aquifer has less than 100 feet of saturated thickness whereas only 5 percent has more than 600 feet of saturated thickness. With the exception of Nebraska, at least 40 percent of the High Plains aquifer in each State has less than 100 feet of saturated thickness. Significant areas where the saturated thickness of the aquifer is greater than 600 feet occur only in Nebraska and Wyoming.

The volume of saturated aquifer material contained in the ground-water reservoir also is summarized in table 2. The total volume of saturated material in the High Plains aquifer is 21.8 billion acre-ft, of which about 64 percent is in Nebraska and only 1 percent is in New Mexico. Based on the volume of saturated material and the area of the aquifer, the average saturated thickness of the High Plains aquifer is about 200 


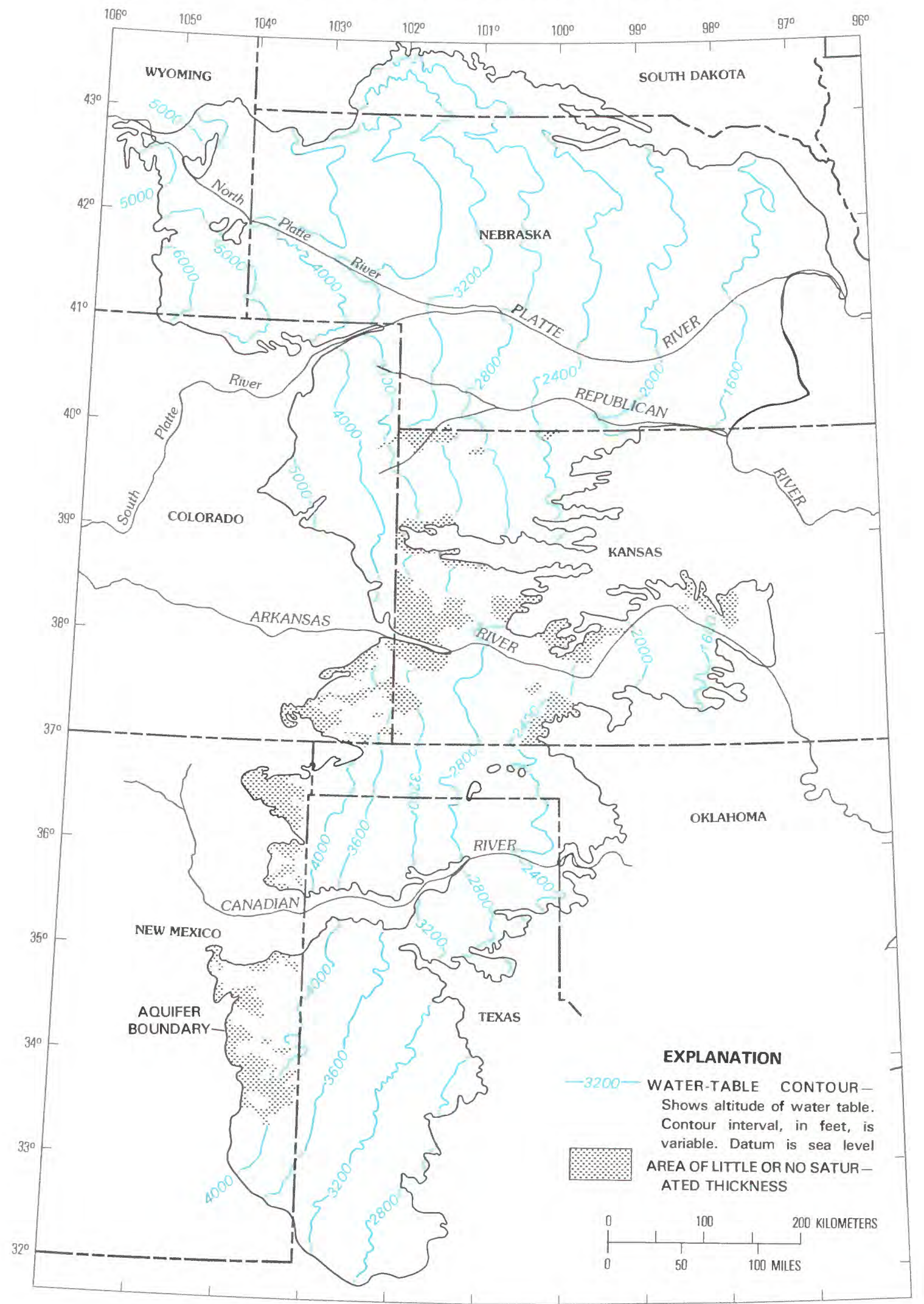

FIGURE 8.-Water table in the High Plains aquifer, 1980 


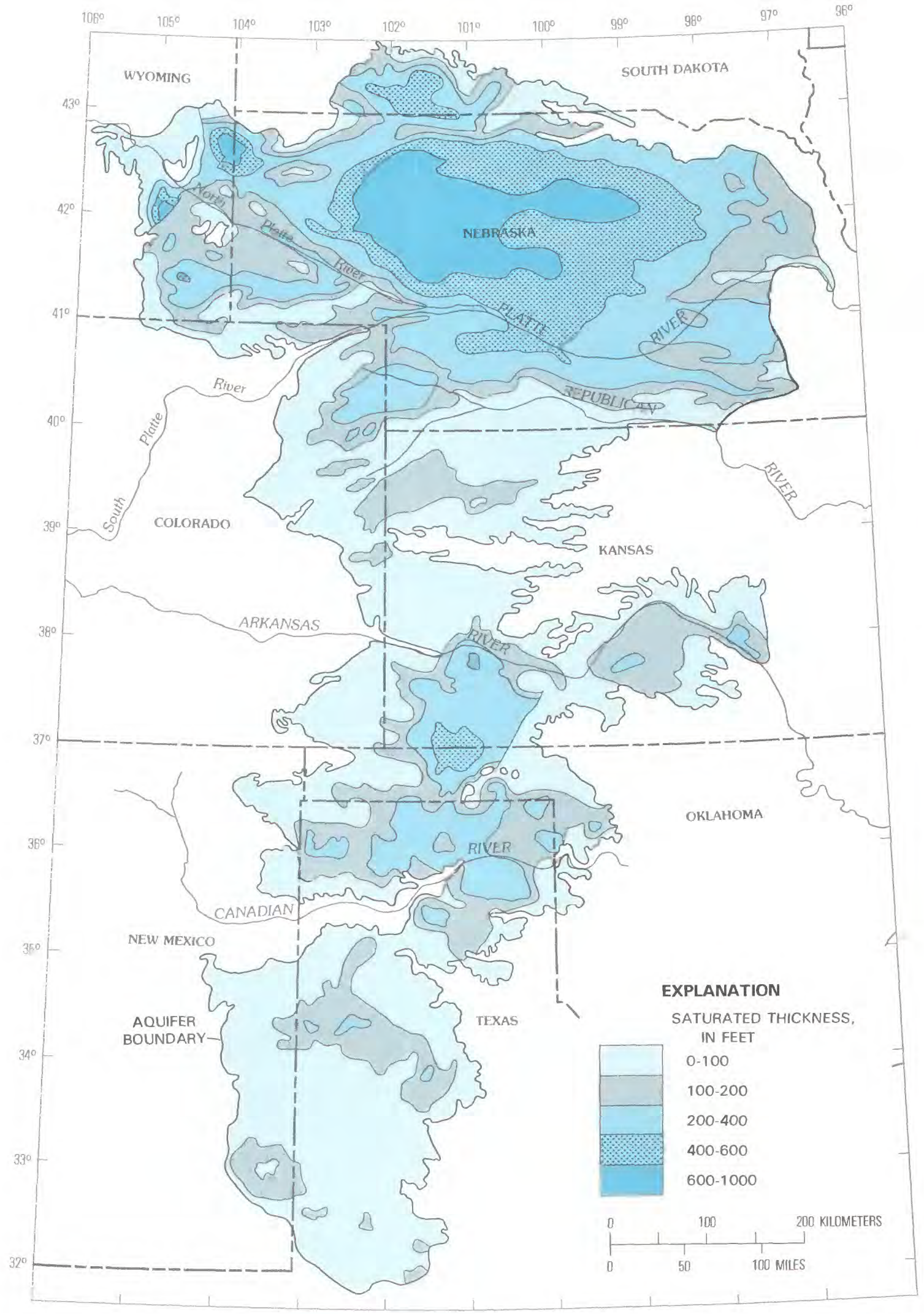

Figure 9.-Saturated thickness of the High Plains aquifer, 1980 (modified from Weeks and Gutentag, 1981). 
feet. The saturated thickness of the aquifer in $\mathrm{Ne}$ braska averages about 340 feet. In the area excluding Nebraska, the saturated thickness of the aquifer averages about 110 feet.

\section{HYDRAULIC CHARACTERISTICS}

Hydraulic conductivity and specific yield are the two principal hydraulic characteristics that control groundwater flow in a water-table aquifer. In order to quantitatively analyze flow in the High Plains aquifer, a knowledge of the values of these characteristics and their distribution within the aquifer is required. Both hydraulic conductivity and specific yield depend on the character of the sediments that comprise the aquifer; therefore, their values can be expected to vary both horizontally and vertically according to the variation in sediment types.

Hydraulic conductivity is defined as the rate of flow of water in cubic feet per day through a cross-sectional area of $1 \mathrm{ft}^{2}$ under a hydraulic gradient of 1 foot per foot at a temperature of about $15^{\circ} \mathrm{C}$. Specific yield is defined as the ratio of (1) the volume of water that the saturated rock will yield by gravity drainage to (2) the total volume of saturated rock. Specific yield is expressed as a dimensionless fraction or percentage. The difference between porosity and specific yield is known as specific retention which is defined as the ratio of (1) the volume of water retained in the rock after gravity drainage to (2) the total volume of the saturated rock. Both hydraulic conductivity and specific yield depend on particle size, shape, sorting, and cementation of the aquifer material.

One of the principal objectives of the High Plains study is to develop a computer model of the aquifer system. Before a computer model of the High Plains aquifer can be developed, it is necessary to determine whether the vertical distribution of sediment types within the aquifer is random or nonrandom. A method was devised by Gutentag and Weeks (1981) to evaluate vertical variability using estimates of hydraulic conductivity and specific yield based on drillers' logs. The method requires statistical computations that describe the vertical distribution of aquifer characteristics determined from drillers' logs.

The method consists of calculating the center of gravity (first moment) and the variance (second moment) of the distribution of transmissivity (product of hydraulic conductivity and thickness) and storage depth (product of specific yield and thickness) relative to the base of aquifer. The center of gravity indicates the position of the centroid of distribution of the aquifer characteristic within the geologic section; the variance is a measure of variability of the aquifer characteristic about the center of gravity. Thus, a center of gravity of 0.5 (onehalf the saturated thickness) indicates that the aquifer characteristic is equally distributed about the centroid of the vertical section. If the mean center of gravity determined from a group of drillers' logs is not significantly different from 0.5 , then the aquifer characteristic (and the sediments that control the characteristic) is distributed randomly in the vertical section. A random distribution (all sediment types are equally likely to occur at any position in the vertical section) can be modeled using vertically-averaged aquifer characteristics. A nonrandom distribution (one sediment type is more likely to occur at a particular position in the vertical section than any other sediment type) can be modeled by developing relationships between vertical position and each aquifer characteristic.

Several thousand drillers' logs from the High Plains aquifer were analyzed using the procedure described above. Hydraulic conductivity and specific yield values were assigned to each lithologic interval described on each log. A computer program was developed and used to calculate the statistics from groups of logs from each of the eight States in the High Plains. The results of this analysis are presented in table 3 which indicates that the centers of gravity of both transmissivity and storage depth are not significantly different from 0.5 .

The method also was tested in Texas by Ashworth (1980) for wells drilled by the Texas Department of Water Resources using drill-hole samples and laboratory analyses. Using these controlled samples at 41 sites in 36 counties, the average centers of gravity for both transmissivity and specific yield were not significantly different from 0.5. Ashworth (1980, p. 20) concluded that " *** there is not an overall relationship between permeability and depth within the Ogallala Formation." Ashworth (1980, p. 20) also noted that specific yield was found to have little variance throughout the saturated zone.

Based on these results, the authors have concluded that on a regional scale, the sediments that comprise the aquifer are distributed randomly in the vertical section. Therefore, the aquifer can be modeled in two dimensions using vertically-averaged values of hydraulic conductivity and specific yield. Because the distribution of sediment types within the High Plains aquifer is virtually random, it is likely that the dominant mode of deposition of the aquifer was by braided streams, probably as individual valley stream deposits that coalesced to form broad alluvial fans. Coarsening-upward and fining-upward sediments are characteristic of braided stream deposits and would result in a random distribution of sediment types in the vertical section. 
TABLE 2.-Distribution and volume of saturated material, High Plains aquifer, 1980

[Modified from Weeks and Gutentag, 1981]

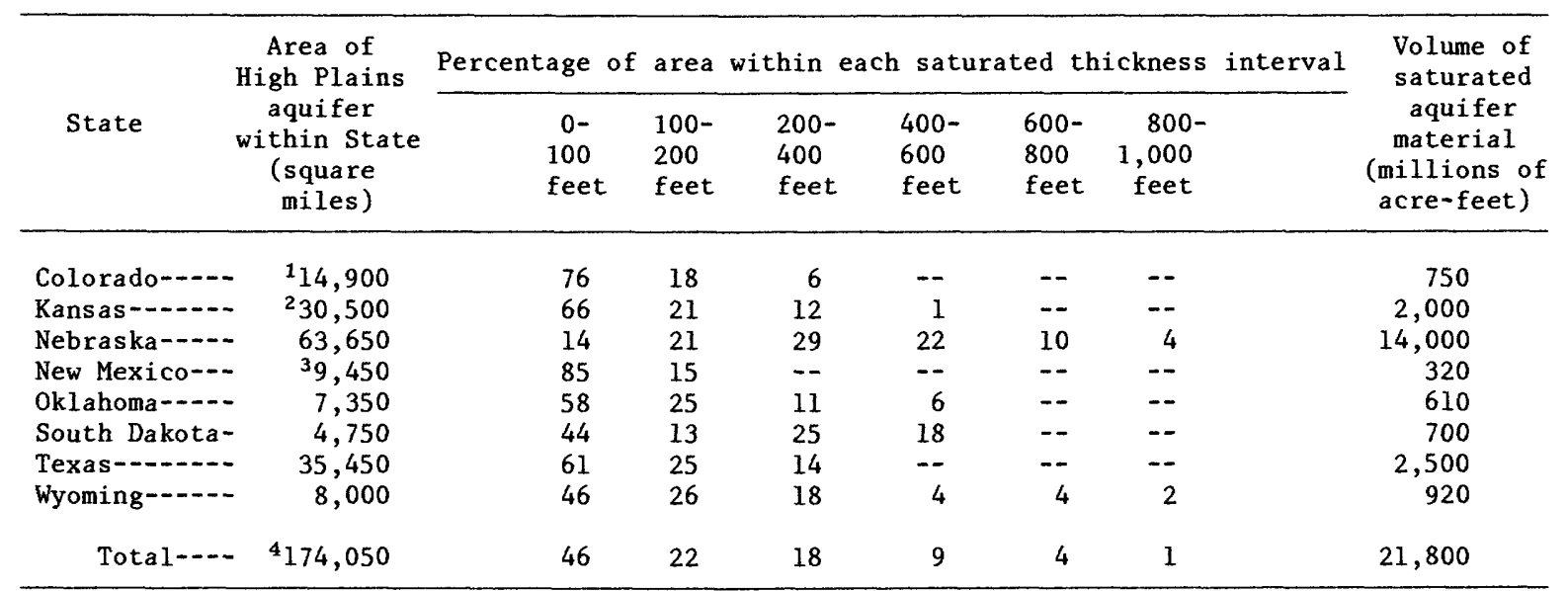

${ }^{1}$ Includes 1,200 square miles with little or no saturated thickness.

${ }^{2}$ Includes 3,200 square miles with little or no saturated thickness.

${ }^{3}$ Includes 2,600 square miles with little or no saturated thickness.

${ }^{4}$ Includes 7,000 square miles with little or no saturated thickness.

The areal distribution of hydraulic conductivity is shown in figure 10. The range in values shown on the map represent the average hydraulic conductivity estimated from drillers' logs. Local changes in lithologic character of the High Plains aquifer result in local hydraulic conductivity changes too variable to show on the scale of this map. The average hydraulic conductivity for the area of the High Plains aquifer in each State and the percentage of the area within each hydraulic conductivity interval are listed in table 4. As shown by figure 10 and table 4 , the hydraulic conductivity of most (68 percent) of the aquifer is 25 to $100 \mathrm{ft} / \mathrm{d}$, although the values range from less than 25 to $300 \mathrm{ft} / \mathrm{d}$.

Differences in hydraulic conductivity in figure 10 reflect areal variations in lithology. Hydraulic conductivity values were assigned to lithologic descriptions from drillers' $\operatorname{logs}$ based on the data in table 5 , which was modified from a table of values prepared for professionally collected sample logs by Reed and Piskin that was published by Lappala (1978). Values for hydraulic conductivity (and specific yield) in table 5 were adjusted for local conditions based on aquifer-test data, local drillers' terminology, and experience of the hydrologist who analyzed the data. The data in table 5 show that fine-grained deposits have much smaller hydraulic conductivities than coarse-grained deposits. Thus, the quantity of fine-grained material interspersed with coarse-grained material controls permeability. The values of hydraulic conductivity in table 5 are less for various lithologic mixtures of coarse- and fine-grained material than for well-sorted material.
The procedure used to estimate the average hydraulic conductivity from drillers' logs requires the calculation of a thickness-weighted average value. Hydraulicconductivity values were assigned to each lithologic unit described by a drillers' log. Each value was multiplied by the thickness of the corresponding lithologic unit to obtain the transmissivity of that unit. The transmissivities of the individual units were summed for the saturated section, and the total was divided by the saturated thickness to obtain the average hydraulic conductivity. These average values, supplemented with data from aquifer tests, were used to prepare the hydraulic conductivity map (fig. 10). Thus, a heterogeneous mixture of fine and coarse material can be expected at any site; and, test drilling would be necessary to determine whether or not the lithology of the aquifer

TABLE 3.-Statistics on the vertical distribution of transmissivity and storage depth in the High Plains aquifer

\begin{tabular}{|c|c|c|c|c|c|}
\hline \multirow[b]{2}{*}{ State } & \multirow{2}{*}{$\begin{array}{l}\text { Number } \\
\text { of logs }\end{array}$} & \multicolumn{2}{|c|}{ Transmissivity } & \multicolumn{2}{|c|}{ Storage depth } \\
\hline & & $\begin{array}{l}\text { Mean center } \\
\text { of gravity }\end{array}$ & $\begin{array}{l}\text { Standard } \\
\text { deviation }\end{array}$ & $\begin{array}{l}\text { Mean center } \\
\text { of gravity }\end{array}$ & $\begin{array}{l}\text { Standard } \\
\text { deviation }\end{array}$ \\
\hline Colorado-.... & 804 & 0.46 & 0.08 & 0.48 & 0.06 \\
\hline Kansas-....... & 1,047 & .48 & .10 & .48 & .07 \\
\hline Nebraska-..... & 88 & .52 & .13 & .51 & .06 \\
\hline New Mexico--- & 58 & .47 & וi & .49 & .08 \\
\hline Oklahoma--...- & 682 & .47 & .10 & .48 & .08 \\
\hline South Dakota- & 205 & .51 & .10 & .51 & .08 \\
\hline Texas- - & 85 & .47 & .11 & .50 & .07 \\
\hline Wyoming--.-- & 107 & .50 & .10 & .50 & .07 \\
\hline Total----- & 3,076 & 0.48 & 0.10 & 0.49 & 0.07 \\
\hline
\end{tabular}




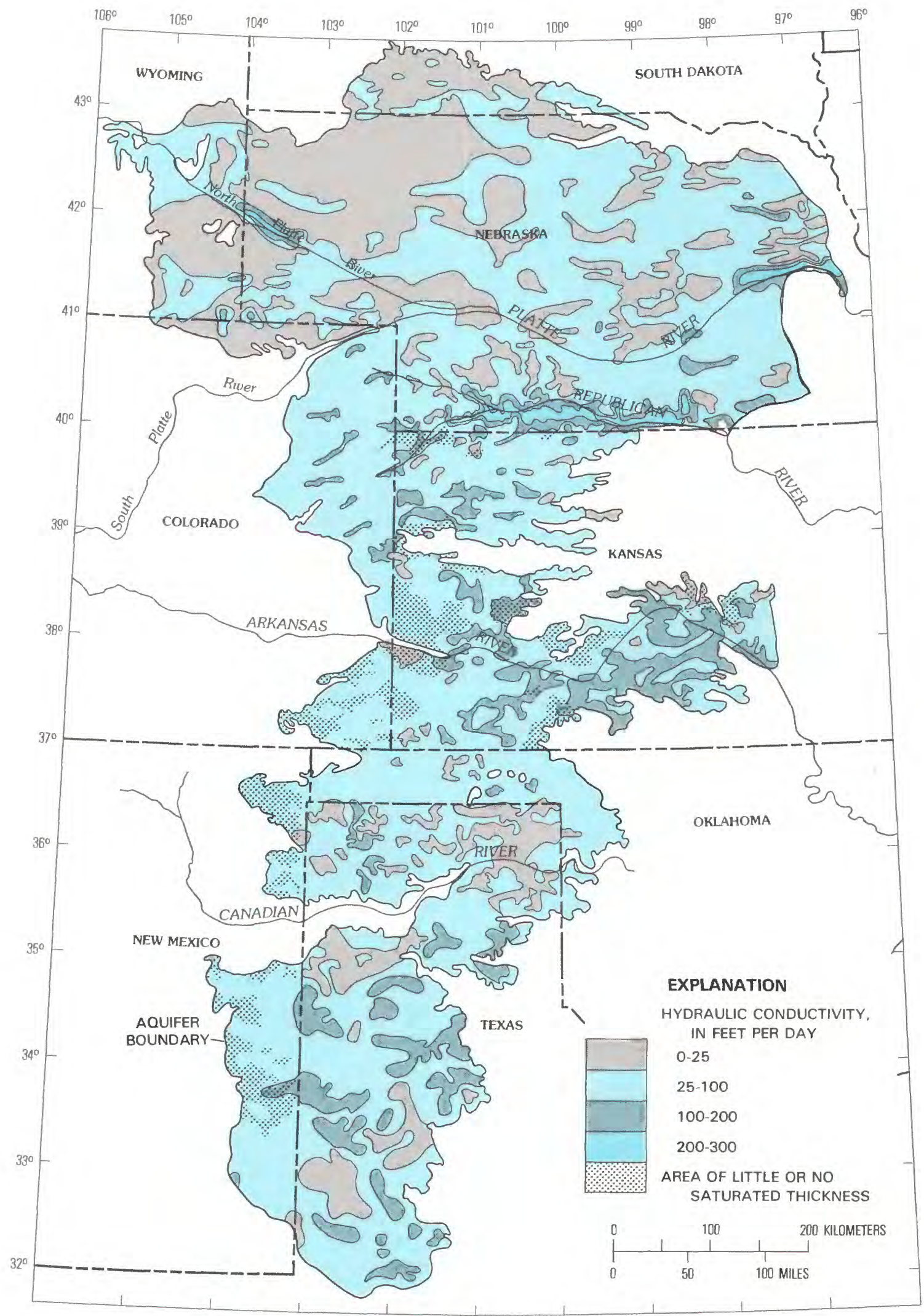

FIGURE 10.-Areal distribution of hydraulic conductivity in the High Plains aquifer. 
TABLE 4.-Distribution of average hydraulic conductivity in the High Plains aquifer

\begin{tabular}{|c|c|c|c|c|c|c|}
\hline \multirow{2}{*}{ State } & \multirow{2}{*}{$\begin{array}{c}\text { Area of } \\
\text { High Plains } \\
\text { aquifer } \\
\text { within State } \\
\text { (square miles) }\end{array}$} & \multicolumn{4}{|c|}{$\begin{array}{l}\text { Percentage of area within each } \\
\text { hydraulic-conductivity interval }\end{array}$} & \multirow{2}{*}{$\begin{array}{c}\text { Average } \\
\text { hydraulic } \\
\text { conductivity } \\
\text { (feet per day) }\end{array}$} \\
\hline & & $\begin{array}{r}0 \\
\text { to } \\
25\end{array}$ & $\begin{array}{r}25 \\
\text { to } \\
100\end{array}$ & $\begin{array}{r}100 \\
\text { to } \\
200\end{array}$ & $\begin{array}{r}200 \\
\text { to } \\
300\end{array}$ & \\
\hline Colorado------ & 14,900 & 11 & 85 & 4 & -. & 60 \\
\hline Kansas- & 30.500 & 3 & 74 & 23 & -- & 81 \\
\hline Nebraska-- & 63,650 & 35 & 59 & 3 & 3 & 53 \\
\hline New Mexico & 9,450 & -. & 98 & 2 & - & 64 \\
\hline OKlahoma- & 7,350 & 4 & 95 & 1 & $-\infty$ & 61 \\
\hline South Dakota-.. & 4,750 & 69 & 31 & -- & -- & 28 \\
\hline Texas--........... & 35,450 & 19 & 67 & 14 & -- & 65 \\
\hline Wyoming------ & 8,000 & 54 & 45 & 1 & -- & 36 \\
\hline Total-_- & 174,050 & 23 & 68 & 8. & 1 & 60 \\
\hline
\end{tabular}

at a selected site indicated a potential yield to wells adequate for the intended use.

The areal distribution of specific yield is shown in figure 11. The range in values shown on the map represents the average specific yield determined from drillers' logs. As with hydraulic conductivity, the specific yield is greatly affected by changes in lithology. Local changes in lithology result in local changes in specific yield too variable to show on the scale of this map. Average specific yield for the area of the High Plains aquifer in each State and the percentage of the area within each specific yield interval are presented in table 6 , which was prepared from a more detailed map than figure 11. As shown by the data in figure 11 and table 6 , the specific yield of most (76 percent) of the aquifer is 10 to 20 percent, although the values range from less than 5 to 30 percent and average 15.1 percent.

TABLE 5.-Hydraulic-conductivity and specific-yield values assigned to lithologic descriptions of the High Plains aquifer

\begin{tabular}{|c|c|c|}
\hline Lithologic description & $\begin{array}{c}\text { Hydraulic } \\
\text { conductivity } \\
\text { (feet per day) }\end{array}$ & $\begin{array}{l}\text { Specific } \\
\text { yield } \\
\text { (percent) }\end{array}$ \\
\hline $\begin{array}{l}\text { Cal iche } \\
\text { Clay-ay and sandstone } \\
\text { Clay, sandy, some gravel- } \\
\text { Gravel, fine to coarse- }\end{array}$ & $\begin{array}{r}10 \\
5 \\
10 \\
15 \\
200\end{array}$ & $\begin{array}{r}5 \\
3 \\
5 \\
8 \\
25\end{array}$ \\
\hline $\begin{array}{l}\text { Grave1, fine } \\
\text { Gravel, medium } \\
\text { Gravel, coarse } \\
\text { Limestone- } \\
\text { Limestone and sand }\end{array}$ & $\begin{array}{r}250 \\
300 \\
350 \\
10 \\
30\end{array}$ & $\begin{array}{r}28 \\
30 \\
35 \\
5 \\
10\end{array}$ \\
\hline $\begin{array}{l}\text { Sand, clayey } \\
\text { Sand, fine } \\
\text { Sand, medium } \\
\text { Sand, coarse } \\
\text { Sand, fine to medium }\end{array}$ & $\begin{array}{l}50 \\
50 \\
80 \\
90 \\
70\end{array}$ & $\begin{array}{l}15 \\
20 \\
25 \\
25 \\
23\end{array}$ \\
\hline $\begin{array}{l}\text { Sand and gravel, cemented } \\
\text { Sand and gravel, clayey- } \\
\text { Sand and gravel, silty } \\
\text { Sand and gravel } \\
\text { Sand, silty- }\end{array}$ & $\begin{array}{r}30 \\
100 \\
130 \\
160 \\
50\end{array}$ & $\begin{array}{l}10 \\
17 \\
20 \\
25 \\
20\end{array}$ \\
\hline $\begin{array}{l}\text { Sandstone- } \\
\text { Silt, clayey- } \\
\text { Silt, sandy- } \\
\text { Top sor } 1\end{array}$ & $\begin{array}{r}10 \\
5 \\
10 \\
5\end{array}$ & $\begin{array}{l}5 \\
3 \\
5 \\
3\end{array}$ \\
\hline
\end{tabular}

TABLE 6.-Distribution of average specific yield in the High Plains aquifer

\begin{tabular}{|c|c|c|c|c|c|c|c|c|}
\hline \multirow{2}{*}{ State } & \multirow{2}{*}{$\begin{array}{l}\text { Area of } \\
\text { High Pla:ns } \\
\text { aquifer } \\
\text { within State } \\
\text { (square miles) }\end{array}$} & \multicolumn{6}{|c|}{$\begin{array}{l}\text { Percentage of area within } \\
\text { each specific-yield interval }\end{array}$} & \multirow{2}{*}{$\begin{array}{l}\text { Average } \\
\text { specific } \\
\text { yield } \\
\text { (percent) }\end{array}$} \\
\hline & & $\begin{array}{r}0 \\
\text { to } \\
5\end{array}$ & $\begin{array}{r}5 \\
\text { to } \\
10\end{array}$ & $\begin{array}{l}10 \\
\text { to } \\
15\end{array}$ & $\begin{array}{l}15 \\
\text { to } \\
20\end{array}$ & $\begin{array}{l}20 \\
\text { to } \\
25\end{array}$ & $\begin{array}{l}25 \\
\text { to } \\
30\end{array}$ & \\
\hline Colorado-...-. & 14,900 & 7 & 6 & 20 & 57 & 10 & -- & 15.4 \\
\hline Kansas--.-.-.- & 30,500 & 3 & 9 & 25 & 42 & 19 & 2 & 16.1 \\
\hline Nebraska--..-- & 63,650 & 2 & 6 & 36 & 49 & 6 & 1 & 15.2 \\
\hline New Mexico--- & 9,450 & -- & 4 & 54 & 35 & 7 & -- & 14.8 \\
\hline Oklahoma--..-.- & 7,350 & -- & 2 & 13 & 49 & 35 & $\mathrm{I}$ & 18.5 \\
\hline South Dakota-- & 4,750 & 26 & 35 & 22 & 14 & 3 & -- & 9.2 \\
\hline Texas--.....- & 35,450 & $\ldots$ & 4 & 40 & 47 & 9 & -- & 15.6 \\
\hline Wyoming & 8,000 & 18 & 70 & 7 & 3 & 2 & -- & 7.6 \\
\hline Total-_-_- & 174,050 & 3 & 10 & 32 & 44 & 10 & 1 & 15.1 \\
\hline
\end{tabular}

Differences in specific yield in figure 11 reflect areal variations in lithology. Specific-yield values were assigned to lithologic descriptions from drillers' logs using table 5 . These values were determined from a study on specific yield by Johnson (1967) and studies of the relation between lithology and specific yield in the High Plains of Nebraska made by the U.S. Geological Survey (M. J. Ellis, U.S. Geological Survey, written commun., 1978). The data in table 5 illustrate that fine-grained deposits have less specific yield than coarse-grained deposits, because specific retention increases as grain-size decreases. The same procedure used to calculate average hydraulic conductivity from drillers' logs was used to determine average specific yield from logs using the data in table 5 . These average values then were used to construct figure 11 .

Both hydraulic-conductivity (fig. 10) and specificyield (fig. 11) maps show complex areal variations that are the result of the complex depositional history of the aquifer. Most of the High Plains aquifer consists of semiconsolidated to unconsolidated deposits resulting from several cycles of deposition. Consequently, there are few areas where the hydraulic conductivity and specific yield maps can be used to interpret the depositional environment of the aquifer. Near the NebraskaKansas State line, both hydraulic-conductivity and specific-yield values are large, because the Republican River has eroded the Ogallala Formation, and only alluvial deposits are present. In parts of Colorado, Nebraska, South Dakota, and Wyoming, both hydraulicconductivity and specific-yield values are small because the aquifer primarily consists of consolidated rocks of the Arikaree and Brule Formations (fig. 3).

\section{FLOW SYSTEM}

The hydraulic characteristics described in the previous section control the storage and movement of water 


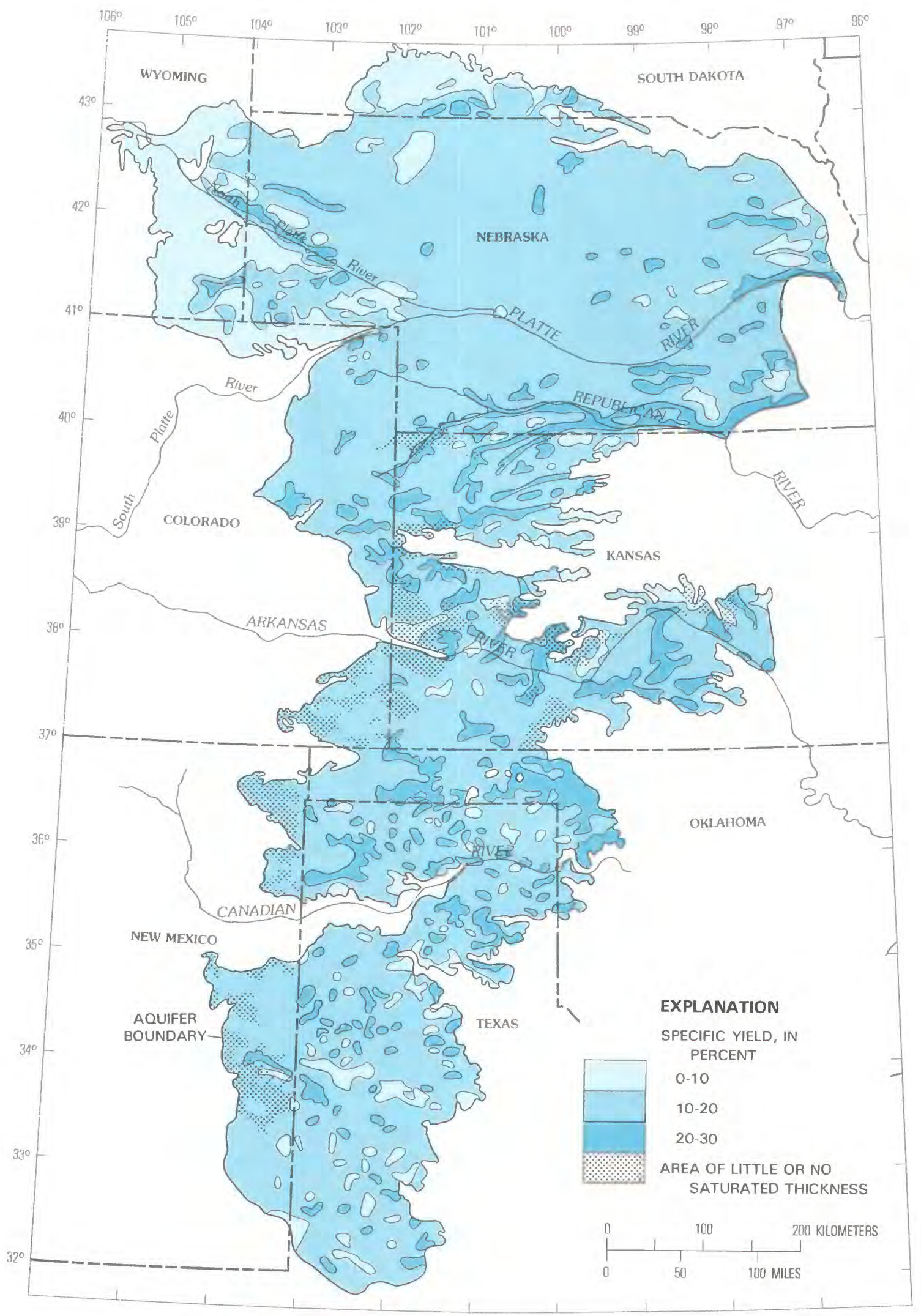

FIgURE 11.-Areal distribution of specific yield in the High Plains aquifer. 
in the High Plains aquifer. In addition, recharge to and discharge from the aquifer control the long-term availability of ground water. For example, when recharge exceeds discharge, the quantity of water in storage increases and the water table rises. Conversely, when discharge exceeds recharge, the quantity of water in storage decreases and the water table declines. Prior to man's activities, the ground-water reservoir operated under natural conditions. That is, the water table was near equilibrium and the quantity of water stored in the reservoir was relatively constant, varying only in response to changes in annual precipitation, streamflow, and vegetation. This section discusses ground-water movement (including recharge and natural discharge) and storage.

Prior to development of ground water by wells, the water table in the High Plains aquifer was near equilibrium or steady-state. The predevelopment water table is shown in figure 12. The map was constructed from water-level data collected prior to significant development of irrigation wells in the High Plains. Development generally progressed northward from New Mexico and Texas during the 1930's, to Oklahoma and Kansas during the 1940's, and Colorado, Nebraska, and Wyoming during the 1950 's and 1960 's. Significant development has not yet occurred in South Dakota. At the scale of this map, there is little difference between figure 12 and the 1980 water-table map in figure 8 except for a slight westward displacement of the 1980 water-table contours caused by pumpage. Consequently, the following discussion generally applies to both current and predevelopment conditions.

Ground-water flow in the High Plains aquifer generally is from west to east in response to the hydraulic gradient or slope of the water table. The flow pattern is shown by arrows in figure 12 . The general direction of ground-water movement is at right angles to the water-table contours in the direction of greatest slope. Based on average values of hydraulic gradient and aquifer characteristics, the velocity of water moving through the aquifer is about $1 \mathrm{ft} / \mathrm{d}$, which is typical of sand and gravel aquifers.

The configuration of the water-table contours in figure 12 is controlled by several factors, including (1) slope of the bedrock base of the aquifer, (2) changes in the thickness and hydraulic conductivity of saturated materials, (3) discharge of ground water into streams, (4) recharge to the aquifer from streams, and (5) recharge by infiltration of water through permeable soils. Typically, many of these factors control the water-table configuration in any particular area. For example, along the western border of the High Plains, especially in southeastern Wyoming, the steep slope of the water surface may be the result of low permeability, reduced thickness of water-bearing materials, a steep slope of the bedrock surface, or a combination of these factors. Flattening of the gradient near the eastern border of the High Plains, may be due to high permeability of the material through which the water is moving, increased thickness of water-bearing materials, a decrease in slope of the bedrock surface, or a combination of these factors.

Up-gradient flexures of water-table contours near streams indicate ground water flows toward and discharges into streams. This is most evident along the North Platte River and Platte River west of $99^{\circ} \mathrm{W}$. longitude and along the Canadian River in Texas. Down-gradient flexures of water-table contours near streams indicate water flows from streams into the aquifer. The 2,000-foot contour crossing the Platte River in Nebraska and the Arkansas River in Kansas (fig. 12) shows this condition. Lack of flexures in areas where contours cross stream valleys may indicate that the water table is below the streambed. This condition is true for most ephemeral (intermittent) streams in the High Plains.

Down-gradient flexures or increased spacing of water-table contours in areas away from perennial streams in figure 12 indicate differences in recharge by infiltration of water through the overlying soil profile. Recharge is indicated by the water-table contours in areas covered by dune sand in Colorado, Kansas, and Nebraska, and to a lesser extent in New Mexico, Oklahoma, and Texas (compare figures 3 and 12). The spacing and flexures of the water-table contours north of the Platte River in Nebraska indicate that large quantities of recharge to the aquifer occur in this area covered by dune sand.

Ground water from the High Plains aquifer discharges naturally to streams and to springs and seeps along the eastern escarpment. Streams that originate in the High Plains generally are ephemeral in their upstream reaches and perennial where their channels are incised to the water table. The Niobrara, Loup, Republican, Smoky Hill, Red, and Brazos Rivers (fig. 1) are among those streams that have their headwaters on the High Plains. Some streams draining the High Plainsthe Platte, Arkansas, Cimarron, Beaver, and Canadian Rivers (fig. 1)-have headwaters in the mountains to the west; but, of these, only the Platte River is perennial throughout its course across the High Plains.

The importance of ground-water discharge to streamflow in the Platte River is illustrated for the 1975 water year in figure 13 modified from Bentall and Shaffer (1979). Downstream from the confluence of the North Platte and South Platte Rivers, there is little 


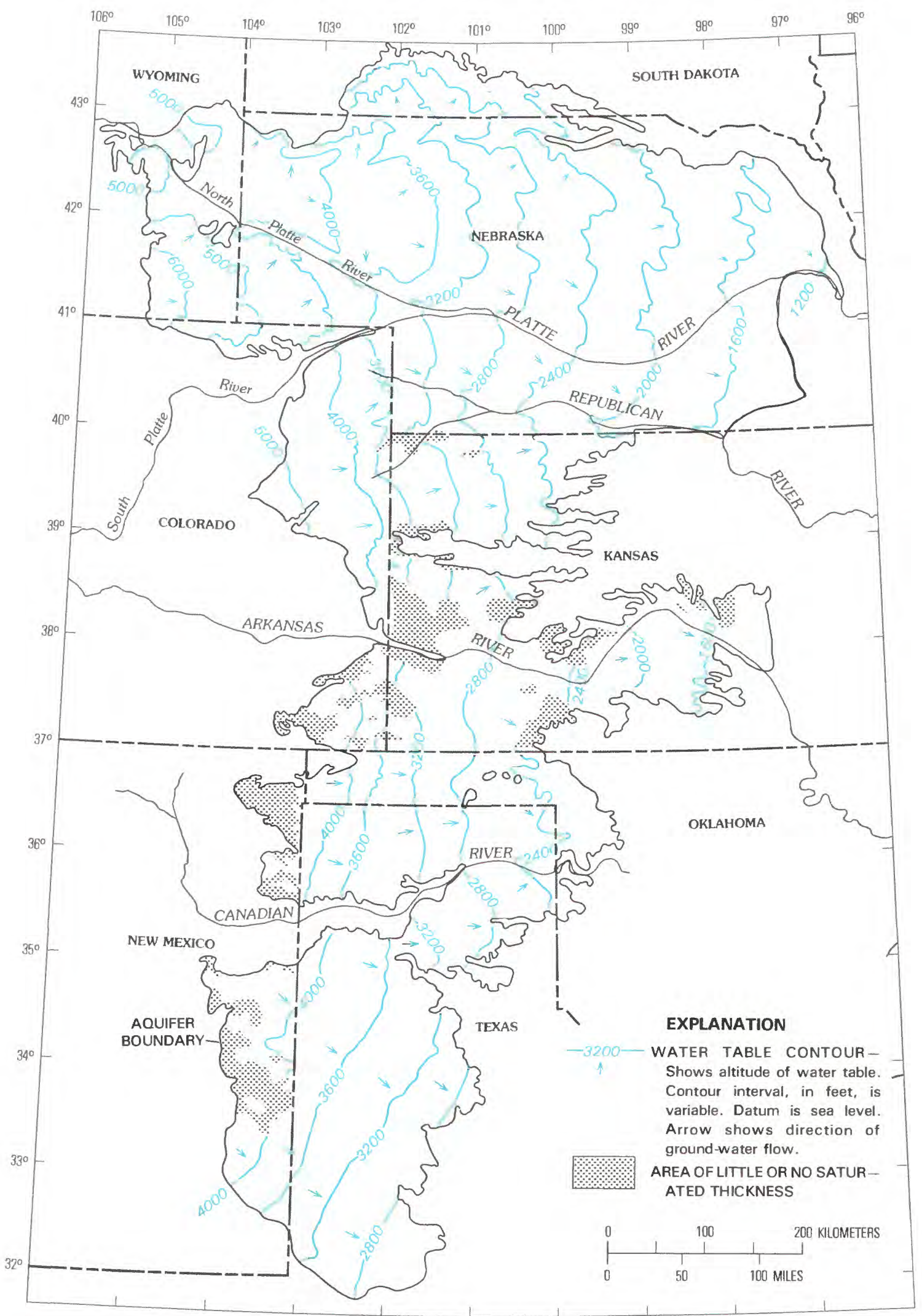

Figure 12.-Predevelopment water table and direction of ground-water flow in the High Plains aquifer. 


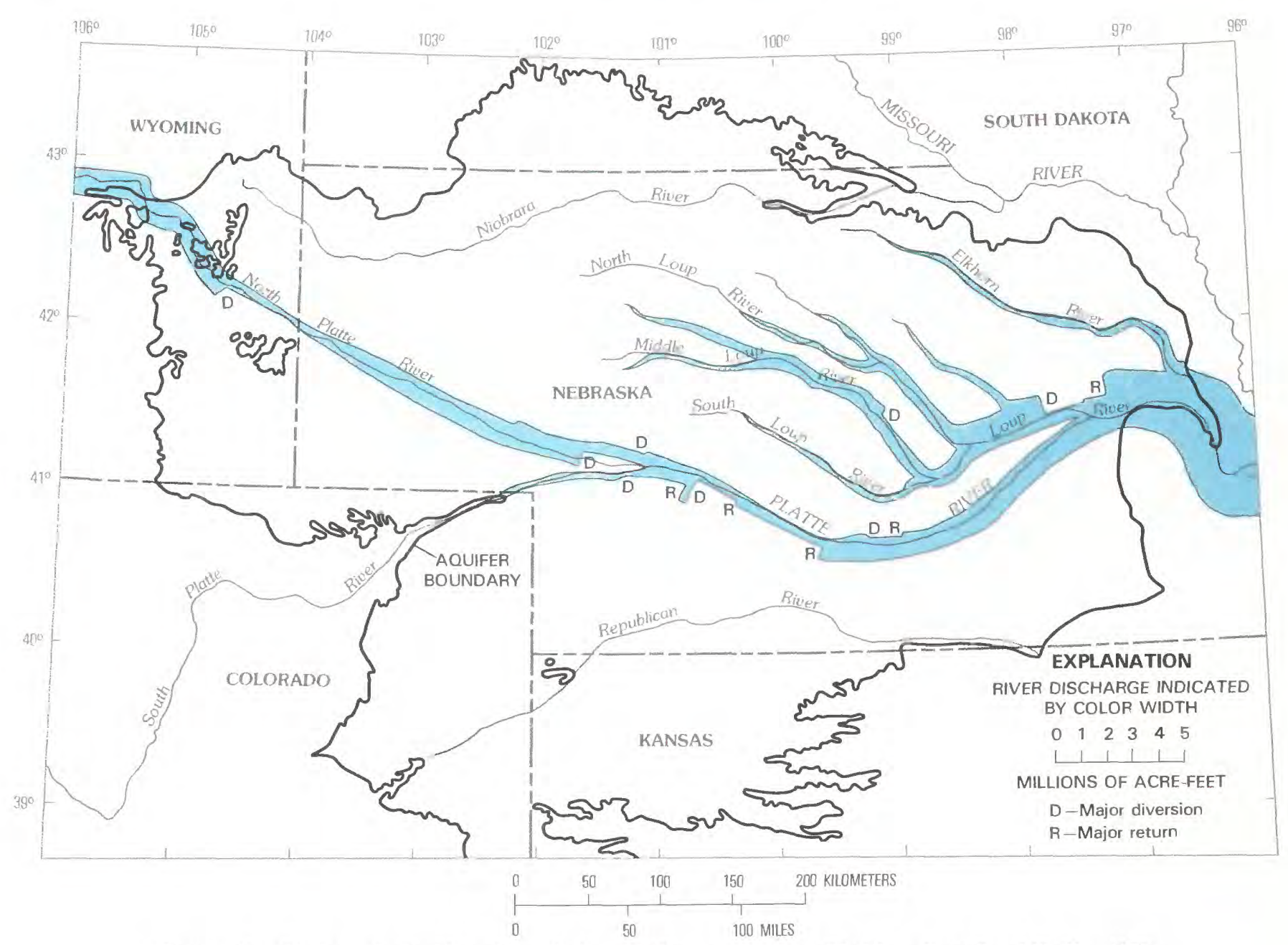

Figure 13.-Discharge in the Platte River drainage, 1975 water year (modified from Bentall and Shaffer, 1979).

surface-water runoff and the gain in streamflow is mostly the result of ground-water discharge from the High Plains aquifer. Streamflow in the Loup River system is almost entirely from ground-water discharge from the sand-dune area in central Nebraska. As shown in figure 13, the gain in streamflow in the Platte River drainage in Nebraska was about 3 million acre-ft during the 1975 water year, most of which was from groundwater discharge. Considering that large quantities of water are diverted and consumed by irrigation, groundwater discharge to streams in the Platte River drainage in Nebraska must have been significantly greater than the apparent gain in streamflow shown in figure 13.

Discharge from the aquifer also occurs in areas where the water table is near enough to the land surface to permit evapotranspiration directly from ground water. Ground-water discharge by evapotranspiration is greatest in areas where phreatophytes such as salt cedar, willows, cottonwoods, and sedges grow mainly along stream valleys. In the area of sand hills in Nebraska, evaporation from numerous lakes in hydraulic connection with the aquifer represents ground-water discharge. The water table is so close to land surface in many places in the sand hills that ground-water discharge by evapotranspiration may equal or exceed that of seepage into streams (Sniegocki, 1959).

Although greatly exaggerated, the east-west sections in figure 7 show the eastward slope of the aquifer base. Ground water moves regionally under the force of gravity in the general direction of the slope of the aquifer base to discharge areas along streams or the aquifer boundary.

As shown on the north-south section (fig. 7), the North Platte River at Lake McConaughy and the Arikaree, Arkansas, and Canadian Rivers have cut their channels through the aquifer into bedrock. These streams in addition to the South Platte, North Loup, Elkhorn, and North Fork Solomon Rivers are gaining streams at the locations shown in figure 7 . At other locations, these and most other streams in the High 
Plains are losing streams, such as the Beaver and Cimarron Rivers in figure 7, and may provide recharge to the aquifer during periods of runoff.

Recharge is the difference between the volume of water that enters the soil profile and the volume of water that leaves the soil by evapotranspiration. Evapotranspiration includes evaporation from the soil and transpiration through plants. As shown in figure 2, pan evaporation in the High Plains is much greater than precipitation; therefore, most precipitation during the growing season returns to the atmosphere by evapotranspiration and little or no recharge occurs depending on the capacity of the soils to store water. Sandy soils generally have large infiltration rates, high permeability, and low field capacity (moisture storage). A generalized soils map of the High Plains is shown in figure 14. Most soils have developed on dune sand or loess. It is probable that the sandy-soil areas shown in figure 14 are important recharge areas for the High Plains aquifer.

Recharge to the aquifer also is derived from streamflow. During periods of normal precipitation, practically no runoff collects in channels of ephemeral (intermittent) streams. However, after exceptionally intense rains, the streams may, in some places, transport large quantities of water. During these rare flows, large quantities of water infiltrate into channel and flood-plain deposits and part of the water probably percolates downward to recharge the aquifer. Gillespie and Slagle (1972) evaluated recharge from Wet Walnut Creek south of La Crosse, Rush County, Kansas (fig. 1). Their study showed that recharge to the aquifer during low-flow periods was only about $0.05 \mathrm{ft}^{3} / \mathrm{s}$ per mile of stream channel although recharge from high flows can be substantial. They noted water-level rises in observation wells ranging from 4 to 14 feet following high-flow periods. Gillespie and Slagle (1972, p. 91) concluded that most of the recharge from Wet Walnut Creek results from high flows. In a related project, Jordan (1977) studied transmission losses of flood flows in ephemeral channels in western Kansas. He estimated the average transmission loss to be 1.3 percent of the flow per mile of stream channel.

Based on the above research, it is probable that high flows in ephemeral streams also are important sources of recharge to the High Plains aquifer. Although ephemeral streams are intermittent sources of recharge, it is possible that a few high flows per decade or century may be a principal source of recharge to the aquifer.

Recharge estimates for the High Plains aquifer are listed in table 7. Values are listed by State and authors. The values represent only a small part of the extensive work on the subject. The estimated recharge rates range from 0.024 inch per year in Texas to 6 inches per year in south-central Kansas. In terms of percentage of mean annual precipitation, the estimates range from 0.1 to 20 percent. Even within individual States, the estimates vary considerably. However, the estimates presented in table 7 consistently show higher recharge rates in areas with sandy soils.

The estimates of recharge presented in table 7 generally result in a long-term average recharge rate. However, depending on the period of analysis, the recharge rate can vary considerably. This is illustrated in table 7 by estimates for Finney County, Kansas, by Meyer and others (1970). Based on the analysis of water-level changes in wells between 1940 and 1952 (a period of greater than normal precipitation), they estimated the average recharge rate to be 1.4 inches per year. In the same study using the water-budget method, the authors estimated the long-term average recharge rate to be only 0.05 inch per year. If the long-term average recharge rate is 0.05 inch per year, then one period of recharge of the same magnitude as that during 1940 52 occurring every 336 years would contribute enough recharge to account for the long-term average recharge rate.

Differences in recharge estimates also are shown in table 7 for Washington County, Colorado. McGovern (1964) estimated the long-term average recharge rate to be 0.95 inch per year based on a water-budget analysis. Longenbaugh and Krishnamurthi (1975) calculated recharge for 1969-73 in Washington County using a soil-moisture model and three observation wells near an ephemeral stream. For the short study period, recharge was estimated to average 4 inches per year. The results showed larger rates of recharge below the ephemeral stream than away from the stream.

Based on the analyses referenced in table 7, recharge rates vary according to climatic, soil, and topographic conditions as well as the period of analyses. With the exception of areas of sandy soil and stream courses, the long-term average annual recharge to the High Plains aquifer under natural conditions is extremely small (a few tenths of an inch) and probably results from infrequent climatic events that cause relatively large quantities of recharge during relatively short periods of time.

Water in storage in the High Plains aquifer varies in response to changes in ground-water discharge and recharge. The volume of drainable water in storage in the High Plains aquifer in 1980 can be estimated by multiplying the volume of saturated material (table 2) by the average specific yield (table 6). The product shown by State in table 8, is an estimate of the volume of drainable water in storage in 1980. The distribution of drainable water in storage is not uniform. The data 


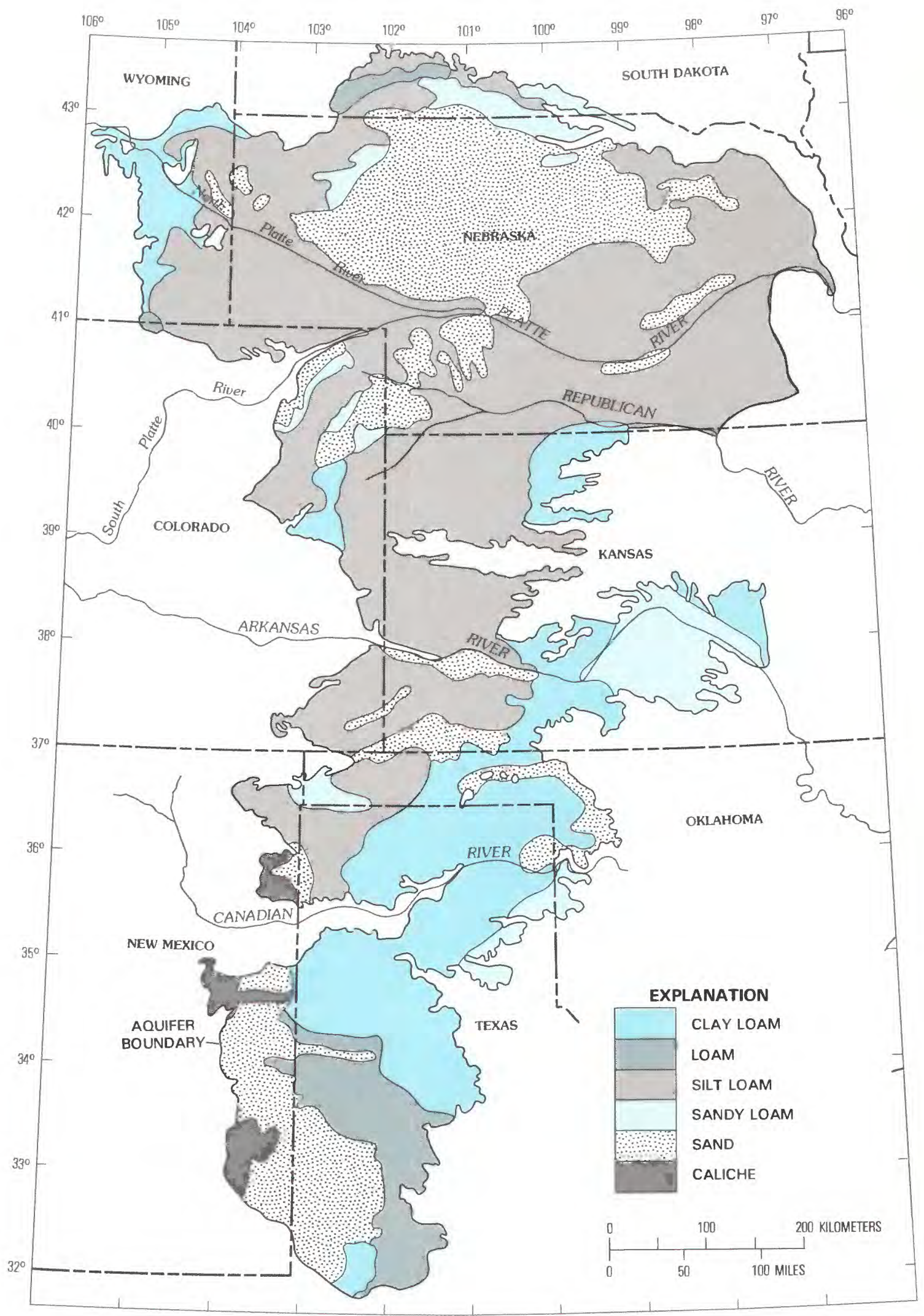

Figure 14.-Soil types in the High Plains. 
TABLE 7.-Recharge estimates for the High Plains aquifer

\begin{tabular}{|c|c|c|c|c|c|}
\hline \multirow[b]{2}{*}{ State } & \multicolumn{3}{|c|}{ Recharge } & \multirow[b]{2}{*}{ Reference } & \multirow[b]{2}{*}{ Remarks } \\
\hline & $\begin{array}{c}\text { In } i \\
\text { per }\end{array}$ & $\begin{array}{l}\text { inches } \\
r \text { year }\end{array}$ & $\begin{array}{l}\text { percentage } \\
\text { mean annual } \\
\text { ecipitation }\end{array}$ & & \\
\hline Colorado-- & 0.80 & $\begin{array}{l}\text { to } 0.95 \\
0.95 \\
0.82\end{array}$ & $\begin{array}{l}5 \\
5 \\
5\end{array}$ & $\begin{array}{l}\text { McGovern and Coffin (1963)--- } \\
\text { McGovern (1964) } \\
\text { Reddell (1967)- } \\
\text { Longenbaugh and Krishnamurthi } \\
\text { (1975). } \\
\text { Kapple and others (1977)---- }\end{array}$ & $\begin{array}{l}\text { Northern High Plains, water-budget method. } \\
\text { Washington County, water-budget method. } \\
\text { Northern High Plains, county averages range from } 0.15 \\
\text { (Kiowa) to } 1.45 \text { inches per year (Yuma), computer-model } \\
\text { analysis. } \\
\text { Washington County, sandy soils, computer-model analysis. } \\
\text { Cheyenne and Kiowa Counties, computer-model analysis. }\end{array}$ \\
\hline Kansas---- & & $\begin{array}{l}6.0 \\
0.30 \\
1.40 \\
0.05 \\
0.19 \\
0.28 \\
0.6 \\
1.85\end{array}$ & $\begin{array}{l}20 \\
2 \\
8 \\
0.3 \\
1 \\
1.5 \\
3 \\
11\end{array}$ & $\begin{array}{l}\text { Williams and Lohman (1949)- } \\
\text { Fader and others (1964) } \\
\text { Meyer and others (1970) } \\
\text { Meyer and others (1970) } \\
\text { Gutentag and Stuliken (1976)-- } \\
\text { Dun lap and others (1980) } \\
\text { Sophocleous (1980) } \\
\text { Barker and others (1983) }\end{array}$ & $\begin{array}{l}\text { Quaternary deposits, south-central Kansas, sandy soils, } \\
\text { water-budget method. } \\
\text { Grant and Stanton Counties, water-budget method. } \\
\text { Finney County, value for } 1940-52 \text { wet period, data from } \\
\text { well hydrographs. } \\
\text { Finney County, long-term water-budget method. } \\
\text { Lane and Scott Counties, water-budget method for dryland } \\
\text { areas. } \\
\text { Wichita County, computer-model analysis. } \\
\text { Pawnee River valley, computer-model analysis. } \\
\text { Arkansas River valley and adjoining sand hills, for dry- } \\
\text { land areas, computer-model analysis. }\end{array}$ \\
\hline Nebraska-- & $\begin{array}{r}5 \\
1 \\
0.50 \\
0 \\
2\end{array}$ & $\begin{array}{l}\text { to } 1.00 \\
5.0 \\
1.0 \\
\text { to } 0.75 \\
0.72 \\
2.40 \\
2.0 \\
5.0\end{array}$ & $\begin{array}{l}4 \text { to } 6 \\
19 \\
5 \\
2 \text { to } 3 \\
3 \\
11 \\
10\end{array}$ & $\begin{array}{l}\text { Cady (1940) } \\
\text { Sniegocki (1959) } \\
\text { Cardwell and Jenkins (1963) } \\
\text { Huntoon (1974) } \\
\text { Emery (1966) } \\
\text { Lappala (1978) } \\
\text { Fred 0tradovsky (U.S. Bureau } \\
\text { of Reclamation, oral commun., } \\
\text { 1981). } \\
\text { Fred 0tradovsky (U.S. Bureau } \\
\text { of Reclamation, oral commun., } \\
\text { 1981). } \\
\text { R. A. Pettijohn and H. H. Chen } \\
\text { (U.S. Geological Survey, } \\
\text { oral commun., 1982). }\end{array}$ & $\begin{array}{l}\text { Box Butte County, flow-line analysis for water-budget } \\
\text { method. } \\
\text { Loup River drainage in sand hills, water-budget method. } \\
\text { Frenchman Creek area of Colorado and Nebraska, water- } \\
\text { budget method. } \\
\text { Big Blue area, computer-model analysis. } \\
\text { Big Blue area, analog-model analysis. } \\
\text { Upper Republican Natural Resources District, computer- } \\
\text { model analysis. } \\
\text { Sand hills, Box Butte County, computer-model analysis. } \\
\text { Sand hills, Holt County, computer-model analysis. } \\
\text { Box Butte County, computer-model analysis, clayey soil-- } \\
1.1 \text { inches per year for cropland and } 1.6 \text { inches per } \\
\text { year for native grassland; sandy soil--2.4 inches per } \\
\text { year for cropland and } 2.8 \text { inches per year for native } \\
\text { grassland. }\end{array}$ \\
\hline New Mexico & & $\begin{array}{l}0.5 \\
0.82 \\
0.39\end{array}$ & $\begin{array}{l}4 \\
6 \\
2.5\end{array}$ & $\begin{array}{l}\text { Theis }(1937) \\
\text { Havens (1966) } \\
\text { Lansford and others (1974)--- }\end{array}$ & $\begin{array}{l}\text { Southern High Plains of Texas and New Mexico, water-budget } \\
\text { method. } \\
\text { Lea County, includes ground-water underflow, water-budget } \\
\text { method. } \\
\text { Southern High Plains, computer-model analysis. }\end{array}$ \\
\hline Oklahoma-- & $\begin{array}{l}0.25 \\
0.20\end{array}$ & $\begin{array}{l}5 \text { to } 0.50 \\
0 \text { to } 2.2\end{array}$ & 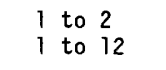 & $\begin{array}{l}\text { Hart and others (1976) } \\
\text { Morton (1980)- }\end{array}$ & $\begin{array}{l}\text { Beaver, Cimarron, and Texas Counties, water-budget method. } \\
\text { Texas County, computer-model analysis. }\end{array}$ \\
\hline $\begin{array}{l}\text { South } \\
\text { Dakota. }\end{array}$ & 1.3 & to 1.8 & 7 to 10 & $\begin{array}{l}\text { K. E. Kolm (U.S. Geological } \\
\text { Survey, oral commun., 1981). }\end{array}$ & Southwestern South Dakota, computer-model analysis. \\
\hline $\begin{array}{l}\text { Texas- - - - } \\
\quad\end{array}$ & 0.024 & $\begin{array}{l}0.50 \\
0.06 \\
0.175 \\
4 \text { to } 0.072 \\
0.183 \\
0.50\end{array}$ & $\begin{array}{c}0.1 \text { to } 0.4 \\
1 \\
3\end{array}$ & $\begin{array}{l}\text { Theis (1937) } \\
\text { White and others (1946) } \\
\text { W. F. Guyton, cited by Rayner } \\
\text { and others (1973). } \\
\text { Brown and Signor (1973)--- } \\
\text { Brutsaert and others (1975)-- } \\
\text { Texas Department of Water } \\
\text { Resources (1981) county } \\
\text { reports. }\end{array}$ & $\begin{array}{l}\text { Southern High Plains of Texas and New Mexico, recharge } \\
\text { adjusted to Texas precipitation, water-budget method. } \\
\text { Southern High Plains, water-budget method. } \\
\text { Parmer County, water-budget method. } \\
\text { Southern High Plains of Texas and New Mexico, water-budget } \\
\text { method. } \\
\text { C. E. Jacob's analysis for tax depletion court case, } \\
\text { Southern High Plains, water-budget method } \\
0.5 \text { inch per year recharge used in computer-model analysis } \\
\text { of: Armstrong, Carson, Dallam, Deaf Smith, Donley, Gray, } \\
\text { Hansford, Harley, Hemphi11, Hutchinson, Lipscomb, Moore, } \\
\text { Ochiltree, 0ldham, Potter, Randal1, Roberts, Sherman, } \\
\text { and Wheeler Counties. } \\
\text { 1.0 inch per year recharge used in computer-model analysis } \\
\text { for the other } 23 \text { counties in the High Plains. }\end{array}$ \\
\hline Wyoming--- & & $\begin{array}{l}0.83 \\
0.56 \\
0.17\end{array}$ & $\begin{array}{l}5.5 \\
3.6 \\
2\end{array}$ & $\begin{array}{l}\text { Morgan }(1946) \\
\text { Crist }(1977) \\
\text { Borchert }(1977)\end{array}$ & $\begin{array}{l}\text { Cheyenne area, water-budget method. } \\
\text { High Plains aquifer, Niobrara County, water-budget method. } \\
\text { Arikaree Formation, central Wyoming, computer-model } \\
\text { analysis. }\end{array}$ \\
\hline
\end{tabular}


TABLE 8.-Distribution of drainable water in storage in the High Plains aquifer, 1980

\begin{tabular}{|c|c|c|}
\hline \multirow{2}{*}{ State } & \multicolumn{2}{|c|}{$\begin{array}{l}\text { Drainable water } \\
\text { in storage }\end{array}$} \\
\hline & Percent & $\begin{array}{l}\text { Millions of } \\
\text { acre-feet }\end{array}$ \\
\hline Colorado---.-- & 3.7 & 120 \\
\hline Kansas--1-- & 9.8 & 320 \\
\hline Nebraska---- & 65.5 & 2,130 \\
\hline New Mexico--- & 1.5 & 50 \\
\hline Okl ahoma-..-... & 3.4 & 110 \\
\hline South Dakota---- & 1.9 & 60 \\
\hline Texas-1- & 12.0 & 390 \\
\hline Wyoming-...---- & 2.2 & 70 \\
\hline Total-n-..-- & 100.0 & 3,250 \\
\hline
\end{tabular}

in table 8 show that Nebraska, with 36 percent of the land area in the High Plains, contains 65.5 percent of the drainable water in storage in the High Plains aquifer. Texas, with 20 percent of the land area in the High Plains, has only 12 percent of the drainable water in storage. New Mexico, with 1.5 percent of the drainable water, has the least volume of water in storage in the High Plains aquifer. The regional variability in the distribution of water in storage can be seen by examining the saturated-thickness map shown in figure 9 and the geohydrologic sections shown in figure 7 . The total volume of drainable water in storage in the High Plains aquifer was estimated at 3.25 billion acre-ft for 1980.

All the drainable water in storage in the High Plains aquifer cannot be recovered for use. The volume of water that can be removed from the aquifer is site specific and depends on the lithology of the site, well construction, saturated thickness, hydraulic conductivity, and specific yield. Because most of the water is used for irrigation, energy costs, well yield, and water quality also need to be considered.

\section{WATER QUALITY}

The High Plains aquifer is the only source of water for irrigation in most of the High Plains. About 95 percent of all water used for irrigation in the study area is pumped from the High Plains aquifer. The agricultural economy of the High Plains depends, in part, on the availability of large quantities of ground water of suitable quality for irrigation. Concentrations of dissolved solids and sodium are of particular importance to irrigation use. Excessive concentrations of dissolved solids affect plant growth; excessive concentrations of sodium affect plant growth and decrease soil tillability and permeability.
Dissolved-solids and sodium concentrations are a hazard to irrigation in the southern part of the High Plains in Texas and in small areas in the High Plains in each of the other seven States. Hazardous concentrations of dissolved solids and sodium occur naturally, except along major streams, where irrigation practices concentrate dissolved constituents.

\section{DISSOLVED SOLIDS}

As a result of geochemical and biochemical interactions between water and the geologic materials through which it flows, ground water contains a variety of dissolved inorganic chemical constituents. The concentration of dissolved solids in ground water can vary by many orders of magnitude. A simple method for categorizing ground water based on dissolved-solids concentration is presented below (Winslow and Kister, 1956).

\section{Category solids, in milligrams per liter}

Fresh

Slightly saline

Moderately saline

Very saline

Brine

Less than 1,000

$1,000-3,000$

$3,000-10,000$

$10,000-35,000$

More than 35,000

To put the concentration ranges in perspective, water containing more than 2,000 to $3,000 \mathrm{mg} / \mathrm{L}$ dissolved solids generally is too mineralized to drink (Freeze and Cherry, 1979). The U.S. Environmental Protection Agency commended limit for dissolved solids in drinking-water supplies is $500 \mathrm{mg} / \mathrm{L}$. Most crops can tolerate water with as much as $500 \mathrm{mg} / \mathrm{L}$ dissolved solids without adverse effects; if leaching or drainage is adequate, concentrations of 500 to $1,500 \mathrm{mg} / \mathrm{L}$ are not likely to be harmful (U.S. Salinity Laboratory Staff, 1954).

The areal distribution of dissolved-solids concentration in water from the High Plains aquifer is shown in figure 15, which is reproduced here from a largerscale map by Krothe and others (1982). Each interval on the map shows the range in concentration that predominates in that area. The chemical composition of the water at selected sites in the High Plains aquifer is presented in table 9 and located by number in figure 15. As shown in table 9, concentrations of sulfate, chloride, fluoride, nitrate, and dissolved solids exceed the U.S. Environmental Protection Agency $(1976,1977)$ 


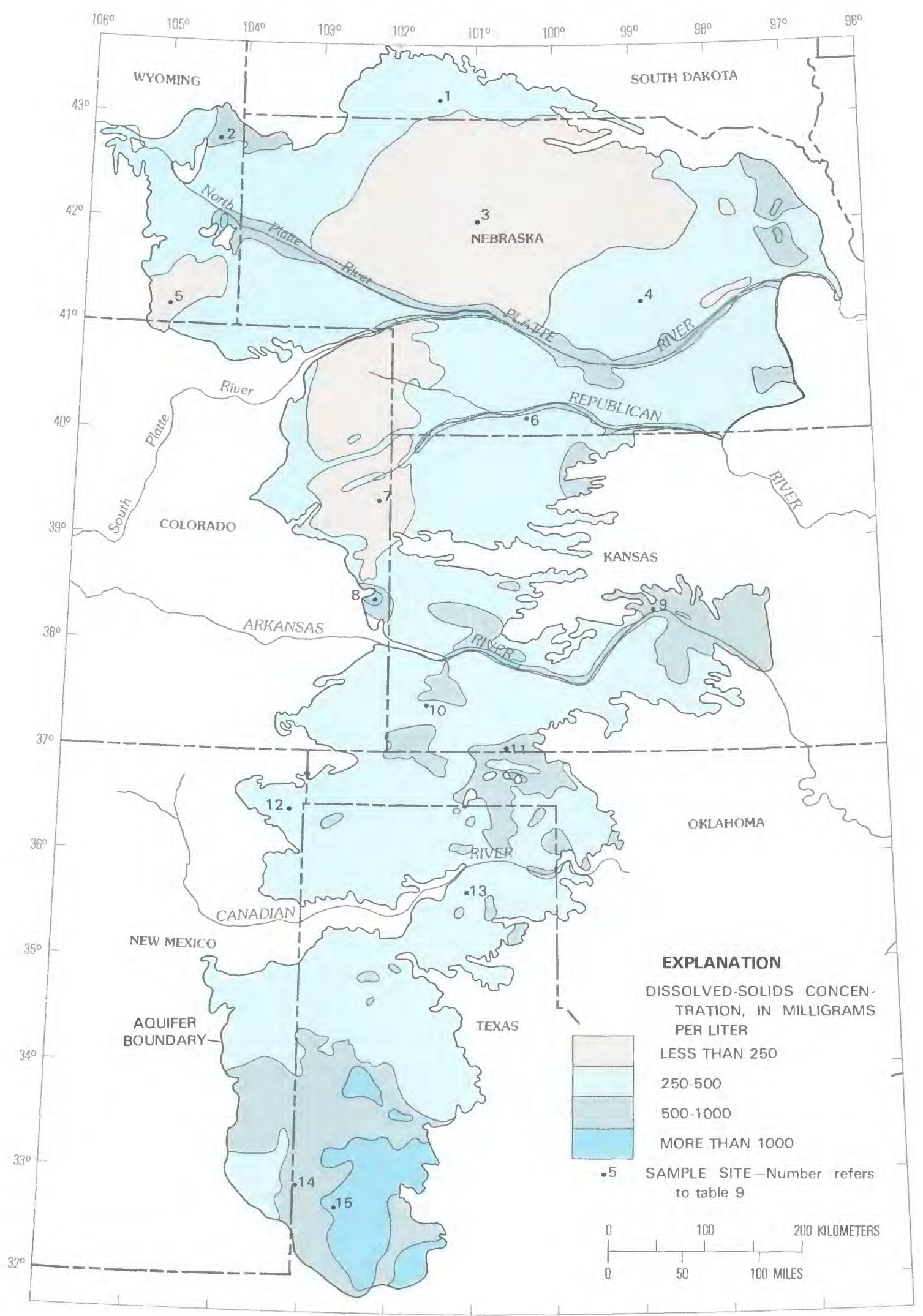

Figure 15.-Dissolved-solids concentration in water from the High Plains aquifer (from Krothe and others, 1982). 
TABLE 9.-Chemical analyses of selected water samples from the High Plains aquifer

[From Krothe and others (1982); values are in milligrams per liter except as indicated; umhos, micromhos at $25^{\circ}$ Celcius; values underlined exceed U.S. Environmental Protection Agency drinking-water regulations, 1976-1977; ARKR=Arikaree Formation or Group; OGLL=Ogallala Formation, SDGV=Quaternary sand and gravel deposits]

\begin{tabular}{|c|c|c|c|c|c|c|c|c|c|c|c|c|c|c|c|c|}
\hline $\begin{array}{l}\text { Sample } \\
\text { number } \\
\text { shown in } \\
\text { figure } 15\end{array}$ & $\begin{array}{c}\text { Geologic } \\
\text { unit }\end{array}$ & $\begin{array}{c}\text { We1l } \\
\text { depth } \\
\text { (feet) }\end{array}$ & $\begin{array}{l}\text { Silica } \\
\left(\mathrm{SiD}_{2}\right)\end{array}$ & $\begin{array}{l}\text { Calcium } \\
\text { (Ca) }\end{array}$ & $\begin{array}{l}\text { Magne- } \\
\text { sium } \\
\text { (Mg) }\end{array}$ & $\begin{array}{c}\text { Sodium } \\
+ \\
\text { Potas- } \\
\text { sium } \\
(\mathrm{Na}+\mathrm{K})\end{array}$ & $\begin{array}{l}\text { Bicar- } \\
\text { bonate } \\
\left(\mathrm{HCO}_{3}\right)\end{array}$ & $\begin{array}{l}\text { Sulfate } \\
\left(\mathrm{SO}_{4}\right)\end{array}$ & $\begin{array}{c}\text { Chloride } \\
\text { (C1) }\end{array}$ & $\begin{array}{l}\text { Fluoride } \\
\text { (F) }\end{array}$ & $\begin{array}{l}\text { Nitrate } \\
\left(\mathrm{NO}_{3}\right)\end{array}$ & $\begin{array}{l}\text { Dissolved } \\
\text { solids } \\
\text { (sum) }\end{array}$ & $\begin{array}{c}\mathrm{pH} \\
\text { (units) }\end{array}$ & $\begin{array}{l}\text { Specific } \\
\text { Conduct- } \\
\text { ance } \\
\text { (umhos) }\end{array}$ & $\frac{\text { Predomi }}{\text { Cation }}$ & $\frac{\text { inant }}{\text { Anion }}$ \\
\hline $\begin{array}{l}1 \\
2 \\
3 \\
4 \\
5\end{array}$ & $\begin{array}{l}\text { ARKR } \\
\text { ARKR } \\
\text { SDGV } \\
\text { OGLL } \\
\text { OGLL }\end{array}$ & $\begin{array}{r}96 \\
100 \\
245 \\
200 \\
250\end{array}$ & $\begin{array}{l}77 \\
54 \\
58 \\
63 \\
28\end{array}$ & $\begin{array}{r}28 \\
122 \\
20 \\
94 \\
45\end{array}$ & $\begin{array}{c}8 \\
29 \\
3.3 \\
14 \\
5.5\end{array}$ & $\begin{array}{l}66 \\
38 \\
12 \\
21 \\
6.4\end{array}$ & $\begin{array}{r}230 \\
446 \\
94 \\
336 \\
157\end{array}$ & $\begin{array}{c}28 \\
24 \\
5.0 \\
18 \\
6.5\end{array}$ & $\begin{array}{c}8.5 \\
40 \\
18 \\
2.3\end{array}$ & $\begin{array}{r}0.1 \\
.5 \\
.2 \\
-. . \\
.4\end{array}$ & \begin{tabular}{l}
1.9 \\
\hdashline 3.0 \\
7.6 \\
7.0
\end{tabular} & $\begin{array}{l}332 \\
\frac{678}{148} \\
403 \\
191\end{array}$ & $\begin{array}{l}7.6 \\
7.5 \\
8.1 \\
7.7 \\
7.4\end{array}$ & $\begin{array}{l}446 \\
926 \\
158 \\
605 \\
281\end{array}$ & $\begin{array}{l}\mathrm{Na} \\
\mathrm{Ca} \\
\mathrm{Ca} \\
\mathrm{Ca} \\
\mathrm{Ca}\end{array}$ & $\begin{array}{l}\mathrm{HCO}_{3} \\
\mathrm{HCO}_{3} \\
\mathrm{HCO}_{3} \\
\mathrm{HCO}_{3} \\
\mathrm{HCO}_{3}\end{array}$ \\
\hline $\begin{array}{r}6 \\
7 \\
8 \\
9 \\
10\end{array}$ & $\begin{array}{l}\text { OGLL } \\
\text { OGLL } \\
\text { OGLL } \\
\text { SDGV } \\
\text { OGLL }\end{array}$ & $\begin{array}{r}200 \\
321 \\
100 \\
100 \\
40\end{array}$ & $\begin{array}{l}58 \\
36 \\
22 \\
20 \\
20\end{array}$ & $\begin{array}{r}56 \\
30 \\
228 \\
108 \\
51\end{array}$ & $\begin{array}{r}15 \\
10 \\
114 \\
21 \\
20\end{array}$ & $\begin{array}{l}19 \\
27 \\
226 \\
114 \\
35\end{array}$ & $\begin{array}{l}200 \\
181 \\
184 \\
248 \\
180\end{array}$ & $\begin{array}{r}13 \\
10 \\
1,170 \\
94 \\
8.1\end{array}$ & $\begin{array}{r}3.9 \\
3.0 \\
143 \\
177 \\
30\end{array}$ & $\begin{array}{l}.8 \\
1.8 \\
4.0 \\
1.0 \\
1.4\end{array}$ & $\begin{array}{l}7 .- \\
3.6 \\
3.9 \\
\frac{32}{12} \\
\end{array}$ & $\begin{array}{r}273 \\
214 \\
2,140 \\
\frac{694}{339}\end{array}$ & $\begin{array}{l}7.7 \\
8.0 \\
7.7 \\
7.5 \\
7.6\end{array}$ & $\begin{array}{r}420 \\
325 \\
2,630 \\
1,235 \\
555\end{array}$ & $\begin{array}{l}\text { Ca } \\
\text { Mixed } \\
\text { Mixed } \\
\text { Mixed } \\
\text { Mixed }\end{array}$ & $\begin{array}{c}\mathrm{HCO}_{3} \\
\mathrm{HCO}_{3} \\
\mathrm{SO}_{4} \\
\mathrm{Mixed} \\
\mathrm{HCO}_{3}\end{array}$ \\
\hline $\begin{array}{l}11 \\
12 \\
13 \\
14 \\
15\end{array}$ & $\begin{array}{l}\text { OGLL } \\
\text { OGLL } \\
\text { OGLL } \\
\text { OGLL } \\
\text { OGLL }\end{array}$ & $\begin{array}{l}260 \\
170 \\
569 \\
150 \\
104\end{array}$ & $\begin{array}{l}23 \\
38 \\
27 \\
58 \\
64\end{array}$ & $\begin{array}{r}63 \\
56 \\
46 \\
72 \\
231\end{array}$ & $\begin{array}{r}19 \\
34 \\
18 \\
20 \\
225\end{array}$ & $\begin{array}{r}245 \\
17 \\
37 \\
44 \\
845\end{array}$ & $\begin{array}{l}210 \\
215 \\
243 \\
221 \\
282\end{array}$ & $\begin{array}{r}94 \\
49 \\
32 \\
104 \\
1,351\end{array}$ & $\begin{array}{r}350 \\
46 \\
28 \\
43 \\
1,109\end{array}$ & $\begin{array}{r}1.0 \\
1.6 \\
.8 \\
1.5 \\
4.0\end{array}$ & $\begin{array}{c}1.7 \\
24 \\
3.9 \\
5.6 \\
4.2\end{array}$ & $\begin{array}{r}\frac{900}{372} \\
312 \\
3, \frac{507}{970}\end{array}$ & $\begin{array}{l}7.7 \\
7.4 \\
8.0 \\
7.3 \\
7.4\end{array}$ & $\begin{array}{r}1,650 \\
628 \\
507 \\
675 \\
5,350\end{array}$ & $\begin{array}{c}\mathrm{Na} \\
\text { Mixed } \\
\text { Mixed } \\
\mathrm{Ca} \\
\mathrm{Na}\end{array}$ & $\begin{array}{c}\mathrm{Cl} \\
\mathrm{HCO}_{3} \\
\mathrm{HCO}_{3} \\
\mathrm{HCO}_{3} \\
\text { Mixed }\end{array}$ \\
\hline
\end{tabular}

primary and secondary drinking-water regulations at some sites. Feder and Krothe (1981) noted that both selenium and fluoride exceeded the regulations in some water samples from the Ogallala Formation.

Excessive fluoride concentrations (greater than $2 \mathrm{mg} /$ L) are a widespread problem in the High Plains aquifer. Fluoride concentrations exceed drinking-water regulations in parts of Colorado (Boettcher, 1964), Kansas (Hathaway and others, 1977), Nebraska (Engberg and Spalding, 1978), New Mexico (Dinwiddie, 1963), Oklahoma (Schoff, 1939, 1943), and Texas (Cronin, 1964; Bassett and others, 1980). Some fluoride in water in the High Plains aquifer is derived from the solution of fluoride minerals in the sand and gravel that comprises most of the aquifer. However, excessive concentrations $(2-8 \mathrm{mg} / \mathrm{L})$ occur where the aquifer contains volcanic-ash deposits or where it is underlain by Cretaceous (especially Lower Cretaceous) rocks. Fluoride is of concern in drinking water; commonly occurring concentrations of fluoride are not of concern in irrigation water.

The chemical composition of water in the High Plains aquifer is related to the concentration of dissolved solids. In general, water in the High Plains aquifer containing less than $250 \mathrm{mg} / \mathrm{L}$ dissolved solids is calcium bicarbonate type water; sodium and sulfate become more prevalent as the concentration of dissolved solids increases from 250 to $500 \mathrm{mg} / \mathrm{L}$. Water from the aquifer containing small concentrations of dissolved solids indicates short residence time and dissolution of calcium and magnesium minerals, such as calcite and dolomite. Larger concentrations of dissolved solids indicate longer residence time, contact with soluble minerals such as gypsum, anhydrite, and halite, or mixing with more mineralized water from bedrock. The chemical character of ground water that exceeds $500 \mathrm{mg} / \mathrm{L}$ dissolved solids is mixed, with ions calcium, sodium, sulfate, and chloride most prevalent.

Most of the water (85 percent) in the High Plains aquifer contains less than $500 \mathrm{mg} / \mathrm{L}$ dissolved solids as shown in figure 16. About 27 percent of the volume of water in the High Plains aquifer contains less than $250 \mathrm{mg} / \mathrm{L}$ dissolved solids and 15 percent of the volume of water in the aquifer contains more than $500 \mathrm{mg} / \mathrm{L}$ dissolved solids. Only 3 percent of the volume of water in the aquifer exceeds $1,000 \mathrm{mg} / \mathrm{L}$ dissolved solids, most of which is in Texas. Generally, the largest concentrations of dissolved solids in water from the High Plains aquifer are less than $3,000 \mathrm{mg} / \mathrm{L}$ except where water has been contaminated by saline water.

Water in the High Plains aquifer in parts of Colorado, Kansas, Nebraska, and Wyoming contains less than $250 \mathrm{mg} / \mathrm{L}$ dissolved solids (fig. 15). A large part of this area in Colorado and Nebraska is covered by sandy soils and dune sands. The concentration of dissolved solids in the area covered by sand is less than 250 $\mathrm{mg} / \mathrm{L}$ because recharge to the aquifer from precipitation is relatively large and most soluble material already has been removed from the sand.

In many areas shown in figure 15 , water in the aquifer contains 500 to $1,000 \mathrm{mg} / \mathrm{L}$ dissolved solids, and in some areas, more than $1,000 \mathrm{mg} / \mathrm{L}$. The water chemistry in these areas appears to be related to bedrock geology. Except south of the Canadian River, the age of the geologic units underlying the High Plains aquifer increases from north to south and from west to east (fig. 4). The age of the bedrock ranges from Tertiary to Permian and, in general, the older rocks contain more soluble minerals than the younger rocks.

The bedrock can affect the chemical composition of 


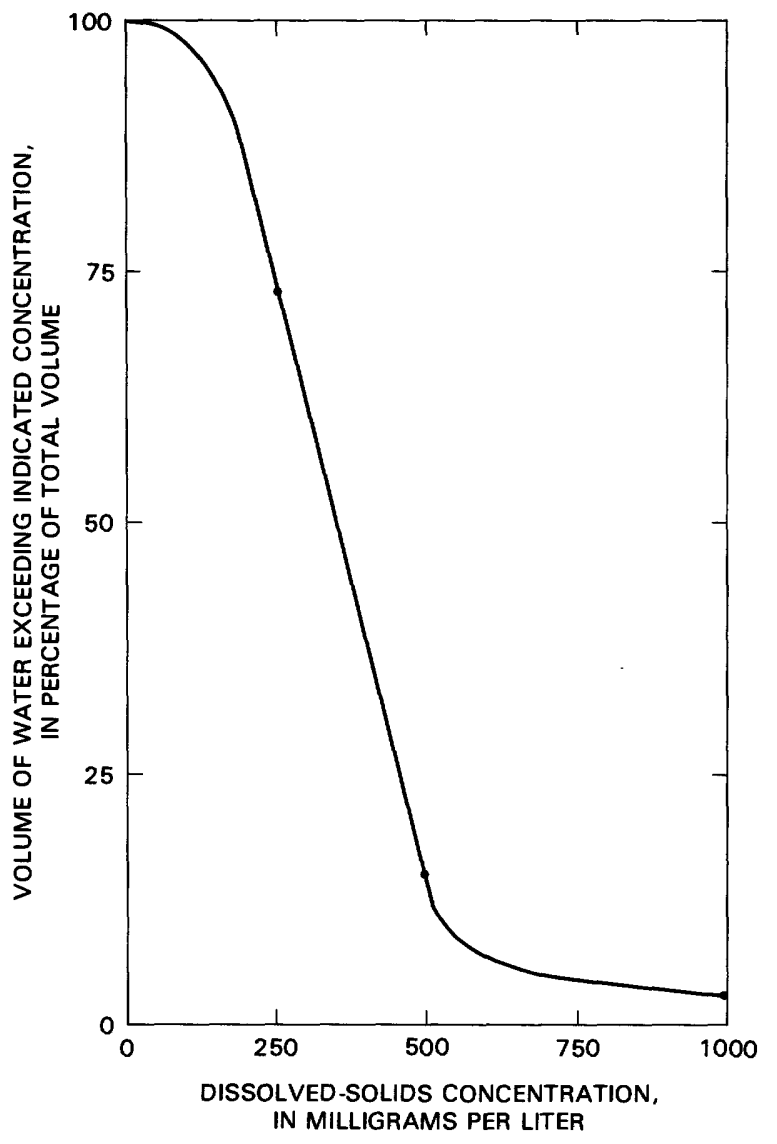

FIGURE 16.-Percentage volume of water in the High Plains aquifer exceeding indicated concentration of dissolved solids.

water in the aquifer in several ways. Water at the base of the aquifer in contact with the bedrock can dissolve minerals and transport solutes through the aquifer by ground-water flow and diffusion. Water containing large concentrations of solutes within the bedrock can flow from the bedrock into the aquifer in response to hydraulic-head differences. Also, dissolution of minerals from reworked bedrock material contained in the aquifer since deposition can affect water chemistry.

In parts of northeastern Nebraska, the High Plains aquifer includes reworked bedrock material of marine origin. Wells in these areas do not yield adequate quantities of water for irrigation and the dissolved-solids concentration in ground water may exceed $1,000 \mathrm{mg} / \mathrm{L}$ (fig. 15). The largest concentration of dissolved solids reported was $2,120 \mathrm{mg} / \mathrm{L}$.

The concentration of dissolved solids in water from the High Plains aquifer exceeds $1,000 \mathrm{mg} / \mathrm{L}$ near outcrops of Late Cretaceous age in southeastern Wyoming (fig. 15). The bedrock units underlying the aquifer in this area are the Upper Cretaceous Lance Formation and the Tertiary Chadron and Brule Formations of the White River Group. Rapp and others (1957) reported that the dissolved-solids concentration in water from the Lance Formation ranged from 416 to $1,250 \mathrm{mg} / \mathrm{L}$ and exceeded $1,000 \mathrm{mg} / \mathrm{L}$ in 2 of 7 water samples. Water in the Lance Formation generally is under artesian pressure (Rapp and others, 1957) and may be moving into the High Plains aquifer.

The concentration of dissolved solids in water from the aquifer exceeds $1,000 \mathrm{mg} / \mathrm{L}$ north of the Arkansas River in Colorado. The largest concentration of dissolved solids reported by Boettcher (1964) in this area was $2,560 \mathrm{mg} / \mathrm{L}$. The aquifer is underlain by the Smoky Hill Marl Member of the Niobrara Formation of Late Cretaceous age. The Smoky Hill Marl Member is "practically impermeable" and contains gypsum (calcium sulfate) crystals according to Boettcher (1964). Water in the aquifer contains sulfate as the dominant anion (table 9 , sample 8 ), which is attributed to gypsum in the bedrock. Because the Smoky Hill is not known to yield water to wells, the chemistry of water in the High Plains aquifer probably is affected by solution of gypsum at the bedrock contact or in wells that are drilled through the aquifer into bedrock.

In parts of south-central and southwestern Kansas, the High Plains aquifer is underlain by Permian age bedrock (fig. 4) containing salt beds and saline water. In this area, water in the aquifer contains 500 to 1,000 $\mathrm{mg} / \mathrm{L}$ dissolved solids (fig. 15). The water type is mixed with large proportions of sodium and chloride (table 9, sample 9) indicating that water from the Permian bedrock may be entering the aquifer.

Permian bedrock also underlies the High Plains aquifer in parts of southwestern Kansas, western Oklahoma, and northern Texas (fig. 4). Water in the aquifer in this area typically contains 250 to $500 \mathrm{mg} / \mathrm{L}$ dissolved solids but concentrations exceed $1,000 \mathrm{mg} / \mathrm{L}$ near Permian outcrops in Oklahoma (fig. 15). As shown in table 9, sample 11, water in the aquifer is a sodium chloride type, which indicates that saline water from the Permian bedrock is entering the aquifer. The largest dissolved-solids concentration noted in water from the aquifer in this area was $6,200 \mathrm{mg} / \mathrm{L}$.

In the southern High Plains of New Mexico and Texas, the aquifer is underlain by Triassic, Jurassic, and Lower Cretaceous bedrock (fig. 4). The Lower Cretaceous rocks were deposited in a deep-water marine environment. Water in these rocks is very mineralized and probably is moving into the High Plains aquifer in response to hydraulic-head differences. As shown in figure 15 and table 9 (samples 14 and 15), water in the aquifer in the southern High Plains contains excessive concentrations of dissolved solids and unusually large proportions of magnesium, sodium, chloride, and sulfate. This probably is caused by the movement of solutes from the marine bedrock into the aquifer. Also, 
Reeves and Miller (1978) proposed that seepage from saline lakes or playas contributes to the relatively large dissolved-solids concentration found in water from the aquifer in the southern High Plains of Texas. The largest concentration of dissolved solids in water from the aquifer noted during this study was $20,200 \mathrm{mg} / \mathrm{L}$ reported by Rettman and Leggat (1966, p. 169) in Gaines County, Texas. This anomalous concentration was caused by contamination from disposal of oilfield brines in surface pits. Generally, the dissolved-solids concentration in water from the High Plains aquifer in southern Texas is less than $3,000 \mathrm{mg} / \mathrm{L}$.

The concentration of dissolved solids in water in the High Plains aquifer near major streams is affected by irrigation practices. Salts that accumulate in the soil due to evapotranspiration are dissolved and flushed with irrigation water. In stream valleys where the water table is near land surface, the salts that were dissolved from the soil are transported to the aquifer. As shown in figure 15, the concentration of dissolved solids in ground water along the Arkansas, Platte, and Republican Rivers generally is 500 to $1,000 \mathrm{mg} / \mathrm{L}$ and exceeds $1,000 \mathrm{mg} / \mathrm{L}$ along parts of the South Platte and Arkansas Rivers.

\section{SODIUM}

The areal distribution of sodium concentration in water from the High Plains aquifer is shown in figure 17 , which is reproduced here from a larger scale map by Krothe and others (1982). Each interval on the map shows the range in sodium concentration that predominates in that area. Chemical data from 28 water samples from the High Plains aquifer are presented in table 10 and located by number in figure 17. The table includes the data needed to evaluate the salinity and sodium hazards associated with the use of water for irrigation discussed later in this report. These 28 chemical analyses were selected because they are representative of the variations in the concentrations of the cations calcium, magnesium, and sodium found in water from the High Plains aquifer. The sodium hazard associated with the use of water for irrigation is determined by the concentrations of these cations.

TABLE 10.-Chemical data from selected water samples from the High Plains aquifer

[mg/L, milligrams per liter; meq/L, milliequivalents per liter; $\mu$ mho, micromhos per centimeter at $25^{\circ} \mathrm{Celsius]}$

\begin{tabular}{|c|c|c|c|c|c|c|c|c|c|c|}
\hline \multirow{2}{*}{$\begin{array}{c}\text { Sample } \\
\text { number in } \\
\text { figure } 17\end{array}$} & \multirow{2}{*}{$\begin{array}{l}\text { Geo- } \\
\text { Togic } \\
\text { unit }\end{array}$} & \multirow{2}{*}{$\begin{array}{l}\text { We11 } \\
\text { depth } \\
\text { (feet) }\end{array}$} & \multicolumn{2}{|c|}{ Calcium } & \multicolumn{2}{|c|}{ Magnes ium } & \multicolumn{2}{|c|}{ Sodium } & \multirow{2}{*}{$\begin{array}{l}\text { Specific } \\
\text { conductance } \\
(\mu \text { mhos })\end{array}$} & \multirow{2}{*}{$\begin{array}{l}\text { Sodium } \\
\text { adsorption } \\
\text { ratio }\end{array}$} \\
\hline & & & $(\mathrm{mg} / \mathrm{L})$ & $(m e q / L)$ & $(\mathrm{mg} / \mathrm{L})$ & $(\mathrm{meq} / \mathrm{L})$ & $(\mathrm{mg} / \mathrm{L})$ & (meq/L) & & \\
\hline $\begin{array}{l}1 \\
2 \\
3 \\
4 \\
5\end{array}$ & $\begin{array}{l}\text { ARKR } \\
\text { ARKR } \\
\text { ARKR } \\
\text { OGLL } \\
\text { SDGV }\end{array}$ & $\begin{array}{r}150 \\
96 \\
100 \\
220 \\
245\end{array}$ & $\begin{array}{r}57 \\
28 \\
122 \\
40 \\
20\end{array}$ & $\begin{array}{l}2.84 \\
1.40 \\
6.09 \\
2.00 \\
1.00\end{array}$ & $\begin{array}{c}2.4 \\
8.3 \\
29 \\
6.7 \\
3.3\end{array}$ & $\begin{array}{r}0.20 \\
.68 \\
2.39 \\
.55 \\
.27\end{array}$ & $\begin{array}{c}77 \\
52 \\
27 \\
8.0 \\
6.6\end{array}$ & $\begin{array}{r}3.35 \\
2.26 \\
1.17 \\
.35 \\
.29\end{array}$ & $\begin{array}{l}617 \\
446 \\
926 \\
305 \\
158\end{array}$ & $\begin{array}{r}2.7 \\
2.2 \\
.6 \\
.3 \\
.4\end{array}$ \\
\hline $\begin{array}{r}6 \\
7 \\
8 \\
9 \\
10\end{array}$ & $\begin{array}{l}\text { BRUL } \\
\text { OGLL } \\
\text { OGLL } \\
\text { OGLL } \\
\text { OGLL }\end{array}$ & $\begin{array}{l}150 \\
200 \\
250 \\
153 \\
368\end{array}$ & $\begin{array}{l}24 \\
94 \\
45 \\
41 \\
29\end{array}$ & $\begin{array}{l}1.20 \\
4.69 \\
2.25 \\
2.05 \\
1.45\end{array}$ & $\begin{array}{c}11 \\
14 \\
5.5 \\
11 \\
9.7\end{array}$ & $\begin{array}{r}.90 \\
1.15 \\
.45 \\
.90 \\
.80\end{array}$ & $\begin{array}{c}59 \\
12 \\
4.4 \\
25 \\
22\end{array}$ & $\begin{array}{r}2.57 \\
.52 \\
.19 \\
1.09 \\
.96\end{array}$ & $\begin{array}{l}485 \\
605 \\
281 \\
400 \\
328\end{array}$ & $\begin{array}{r}2.5 \\
.3 \\
.2 \\
.9 \\
.9\end{array}$ \\
\hline $\begin{array}{l}11 \\
12 \\
13 \\
14 \\
15\end{array}$ & $\begin{array}{l}\text { OGLL } \\
\text { OGLL } \\
\text { OGLL } \\
\text { OGLL } \\
\text { OGLL }\end{array}$ & $\begin{array}{l}200 \\
227 \\
321 \\
100 \\
340\end{array}$ & $\begin{array}{r}56 \\
43 \\
30 \\
228 \\
110\end{array}$ & $\begin{array}{r}2.79 \\
2.15 \\
1.50 \\
11.38 \\
5.49\end{array}$ & $\begin{array}{r}15 \\
17 \\
10 \\
114 \\
48\end{array}$ & $\begin{array}{l}1.23 \\
1.40 \\
0.82 \\
9.38 \\
3.95\end{array}$ & $\begin{array}{c}9.8 \\
24 \\
22 \\
222 \\
47\end{array}$ & $\begin{array}{r}.43 \\
1.04 \\
.96 \\
9.66 \\
2.04\end{array}$ & $\begin{array}{r}420 \\
450 \\
325 \\
2,630 \\
1,060\end{array}$ & $\begin{array}{r}.3 \\
1.3 \\
0.9 \\
3.0 \\
.9\end{array}$ \\
\hline $\begin{array}{l}16 \\
17 \\
18 \\
19 \\
20\end{array}$ & $\begin{array}{l}\text { OGLL } \\
\text { SDGV } \\
\text { OGLL } \\
\text { OGLL } \\
\text { OGLL }\end{array}$ & $\begin{array}{r}320 \\
70 \\
180 \\
178 \\
260\end{array}$ & $\begin{array}{r}320 \\
91 \\
54 \\
33 \\
63\end{array}$ & $\begin{array}{r}15.97 \\
4.54 \\
2.69 \\
1.65 \\
3.14\end{array}$ & $\begin{array}{l}62 \\
12 \\
20 \\
20 \\
19\end{array}$ & $\begin{array}{r}5.10 \\
.99 \\
1.65 \\
1.65 \\
1.56\end{array}$ & $\begin{array}{r}120 \\
80 \\
18 \\
28 \\
240\end{array}$ & $\begin{array}{r}5.22 \\
3.48 \\
.78 \\
1.22 \\
10.44\end{array}$ & $\begin{array}{r}2,100 \\
875 \\
470 \\
435 \\
1,650\end{array}$ & $\begin{array}{r}1.6 \\
2.1 \\
.5 \\
1.0 \\
6.8\end{array}$ \\
\hline $\begin{array}{l}21 \\
22 \\
23 \\
24 \\
25\end{array}$ & $\begin{array}{l}\text { OGLL } \\
\text { OGLL } \\
\text { OGLL } \\
\text { OGLL } \\
\text { OGLL }\end{array}$ & $\begin{array}{l}230 \\
180 \\
560 \\
120 \\
201\end{array}$ & $\begin{array}{l}49 \\
46 \\
54 \\
35 \\
38\end{array}$ & $\begin{array}{l}2.45 \\
2.30 \\
2.69 \\
1.75 \\
1.90\end{array}$ & $\begin{array}{l}29 \\
14 \\
23 \\
30 \\
16\end{array}$ & $\begin{array}{l}2.39 \\
1.15 \\
1.89 \\
2.47 \\
1.32\end{array}$ & $\begin{array}{r}20 \\
100 \\
130 \\
46 \\
47\end{array}$ & $\begin{array}{r}.87 \\
4.35 \\
5.66 \\
2.00 \\
2.04\end{array}$ & $\begin{array}{r}555 \\
855 \\
1,070 \\
612 \\
475\end{array}$ & $\begin{array}{l}.6 \\
3.6 \\
4.1 \\
1.4 \\
1.6\end{array}$ \\
\hline $\begin{array}{l}26 \\
27 \\
28\end{array}$ & $\begin{array}{l}\text { OGLL } \\
\text { OGLL } \\
\text { OGLL }\end{array}$ & $\begin{array}{r}90 \\
95 \\
101\end{array}$ & $\begin{array}{l}108 \\
383 \\
295\end{array}$ & $\begin{array}{r}5.39 \\
19.11 \\
14.72\end{array}$ & $\begin{array}{r}16 \\
177 \\
297\end{array}$ & $\begin{array}{r}1.32 \\
14.56 \\
24.43\end{array}$ & $\begin{array}{r}68 \\
227 \\
1,151\end{array}$ & $\begin{array}{r}2.96 \\
9.87 \\
50.07\end{array}$ & $\begin{array}{r}941 \\
2,900 \\
4,250\end{array}$ & $\begin{array}{r}1.6 \\
2.4 \\
11.3\end{array}$ \\
\hline
\end{tabular}




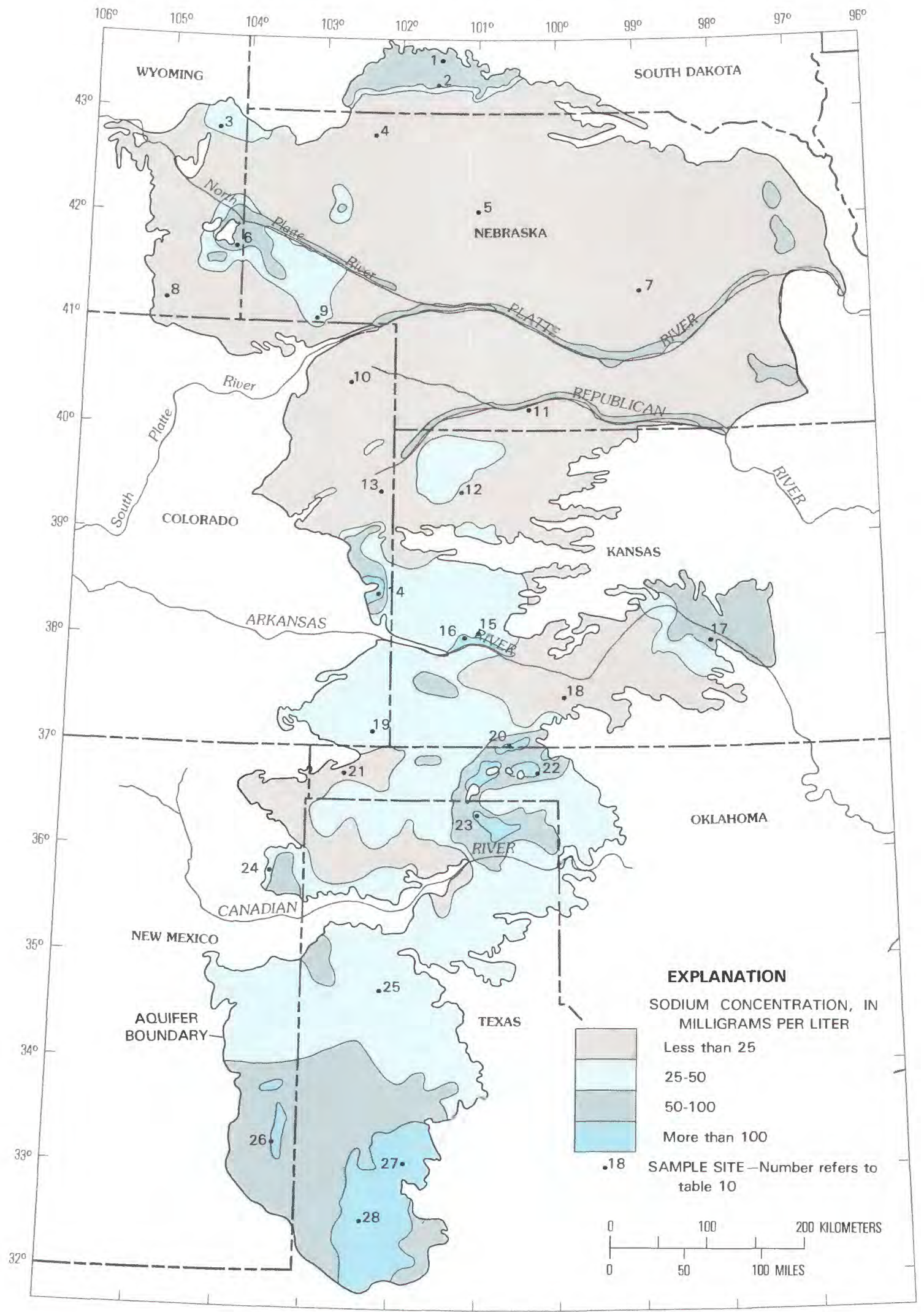

FIGURE 17. Sodium concentration in water from the High Plains aquifer (from Krothe and others, 1982). 
The sodium concentration in water from the High Plains aquifer generally increases from north to south and ranges from less than 25 to more than $100 \mathrm{mg} / \mathrm{L}$ as shown in figure 17. The maximum reported sodium concentration in uncontaminated water from the aquifer was $1,151 \mathrm{mg} / \mathrm{L}$. The concentration of sodium in most of the area of the High Plains aquifer is less than 50 $\mathrm{mg} / \mathrm{L}$ because the aquifer is composed mostly of sand and gravel deposits that contain few sodium minerals. In the northern High Plains, water from the Arikaree Formation (table 10, samples 1, 2, and 3) and the Brule Formation (table 10, sample 6 ) generally contain larger concentrations of sodium than water from the Ogallala Formation (table 10, samples 4 and 7-13) or Quaternary sand and gravel deposits (table 10, sample 5). However, the concentration of sodium in many parts of the High Plains appears to be affected by the bedrock.

In Colorado, sample 14 (table 10) from the High Plains aquifer contains $222 \mathrm{mg} / \mathrm{L}$ sodium. In this area, the aquifer is underlain by the Smoky Hill Marl Member of the Niobrara Formation, which contains marine clays. The sodium concentration probably is increased by ion exchange on clays at the weathered surface of the bedrock or on clays in the aquifer derived from reworked bedrock.

In southwestern Kansas, Oklahoma, and northern Texas, the sodium concentration in water from the aquifer exceeds $100 \mathrm{mg} / \mathrm{L}$ in several places (fig. 17). The concentration of sodium in samples 20,22 , and 23 in table 10 ranges from 100 to $240 \mathrm{mg} / \mathrm{L}$. The bedrock underlying the aquifer in this area is of Permian age and contains salt beds and saline water. Relatively large concentrations of sodium and chloride (table 9, sample 11) indicate that saline water from the Permian rocks may be entering the aquifer.

The sodium concentration also exceeds $100 \mathrm{mg} / \mathrm{L}$ in parts of the High Plains aquifer in New Mexico and Texas, south of the Canadian River (fig. 17). In table 10 , sample 27 from the aquifer contains $227 \mathrm{mg} / \mathrm{L}$ sodium and sample 28 contains $1,151 \mathrm{mg} / \mathrm{L}$ sodium. Most of this area of the aquifer is underlain by Lower Cretaceous rocks (fig. 4) containing mineralized water that may be entering the aquifer. Also, many saline lakes or playas occur in this area (Reeves and Miller, 1978) and seepage from the playas may contribute to the relatively large concentrations of sodium found in water from the aquifer. In some areas, large concentrations of sodium have been caused by disposal of oilfield brines in surface pits (Rettman and Leggat, 1966).

Sodium concentrations in water in the High Plains aquifer near major streams are affected by irrigation practices. In areas of extensive irrigation, sodium is concentrated by evapotranspiration and ion exchange in the soil. In stream valleys where the water table is near land surface, infiltration of irrigation water has resulted in relatively large concentrations of sodium. As shown in figure 17 , the sodium concentration in ground water is 50 to $100 \mathrm{mg} / \mathrm{L}$ along most of the Platte and Republican Rivers in Nebraska, and exceeds 100 $\mathrm{mg} / \mathrm{L}$ along part of the Arkansas River in Kansas.

\section{GROUND-WATER DEVELOPMENT}

Water from the High Plains aquifer is the principal source of supply for irrigated agriculture in the region. Rapid development of irrigation in the High Plains in recent years has transformed the area into one of the major agricultural regions of the United States.

\section{IRRIGATION DEVELOPMENT}

Irrigation began in the High Plains along the Arkansas and Platte Rivers in the late 1800's, when surface water was diverted through ditches to irrigate crops in the stream valleys. Because of the lack of adequate streamflow during dry years, ditch irrigation was unreliable until storage reservoirs were constructed decades later.

Ground-water irrigation in the High Plains also began in the late 1800 's with the use of windmills. However, ground-water development was sporadic until the drought of the 1930's. Spurred by the drought, technological advances in well drilling and pumping plants, inexpensive energy, profitable crop prices, and available financing, ground-water irrigation developed rapidly after the 1930 's.

The density of acreage irrigated by ground water in the High Plains during 1949, 1964, and 1978 is shown in figures 18,19 , and 20 . These density maps were prepared from data published in the Census of Agriculture (U.S. Department of Commerce, 1949, 1964, 1978). During 1949 (fig. 18), most of the acreage irrigated by ground water was in Texas, New Mexico, southwestern Kansas, and along the Platte River in Nebraska. Prior to 1949 , depth to water in the aquifer and land-surface slope were major factors controlling the distribution of irrigation development.

During the 1950 's, irrigation development was spurred again by severe drought. In addition, development of natural-gas fields underlying the High Plains made inexpensive energy available, and irrigation development spread throughout large parts of the High Plains. Prior to the 1960 's, most irrigation wells were drilled in areas where the water table was less than 100 feet below land surface. Since the early 1960 's, development of efficient powerplants for turbine pumps has allowed areas with deeper water to be developed (Jenkins and 


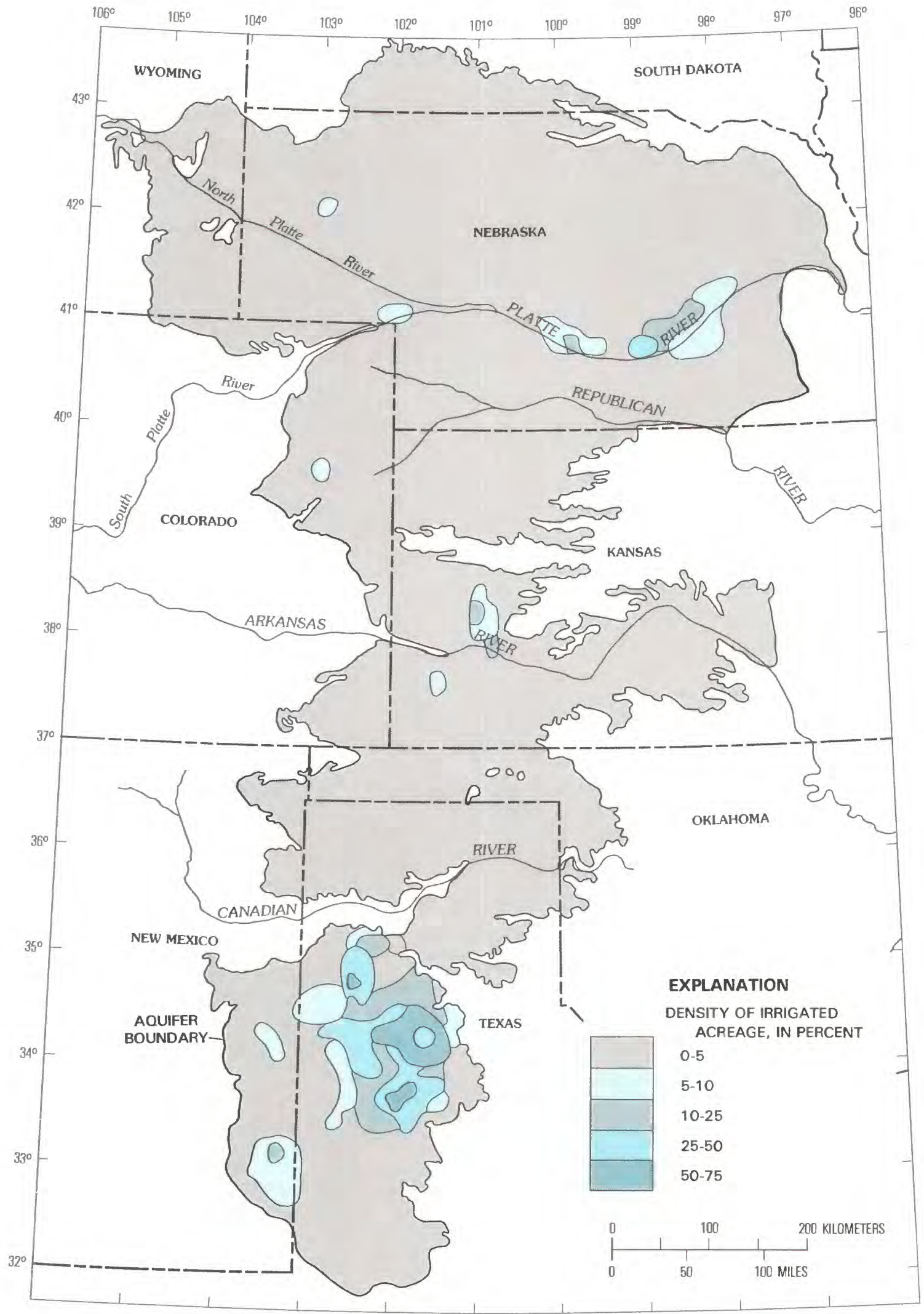

Figure 18. - Density of acreage irrigated by ground water in the High Plains, 1949. 


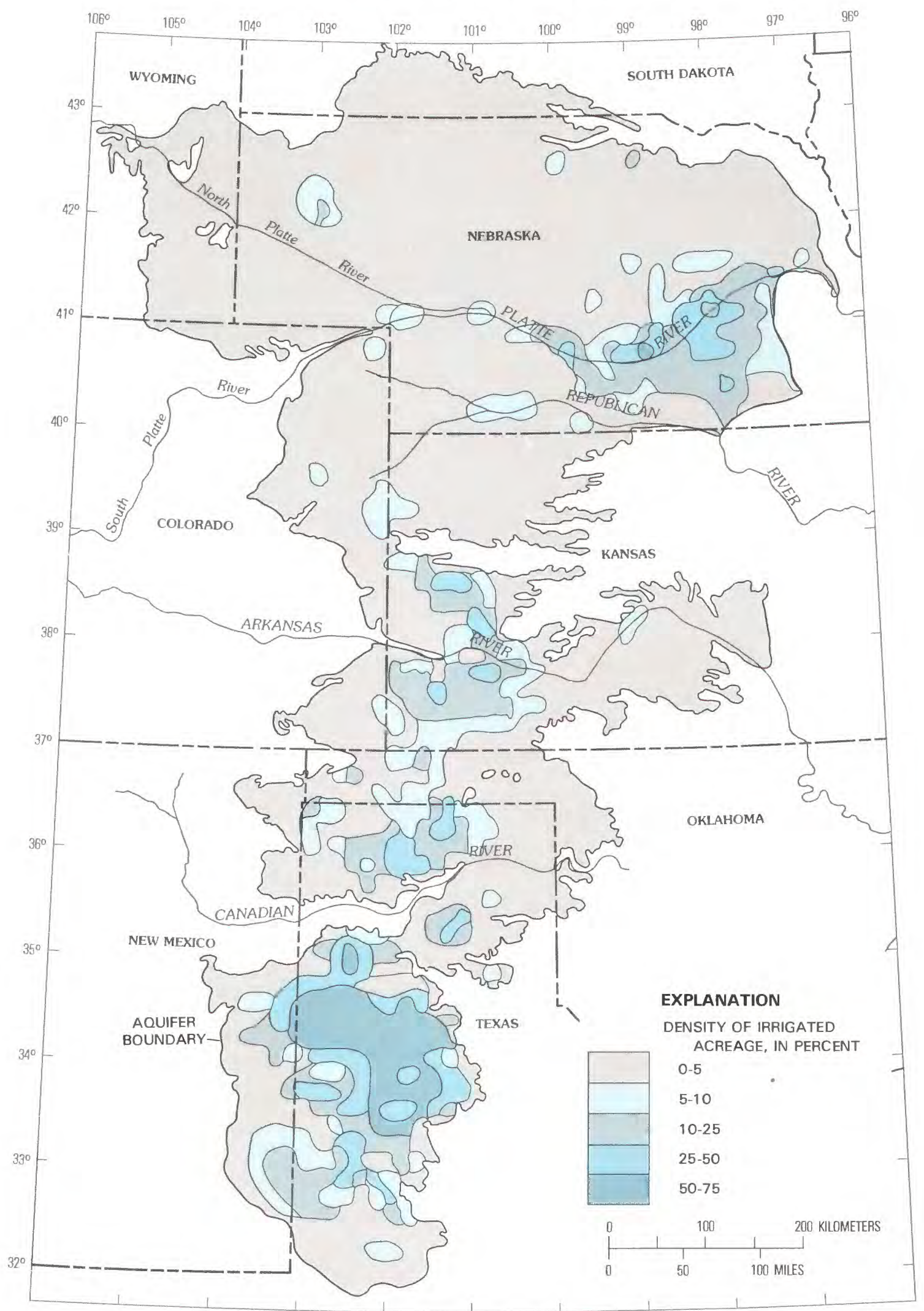

FIGURE 19.-Density of acreage irrigated by ground water in the High Plains, 1964. 


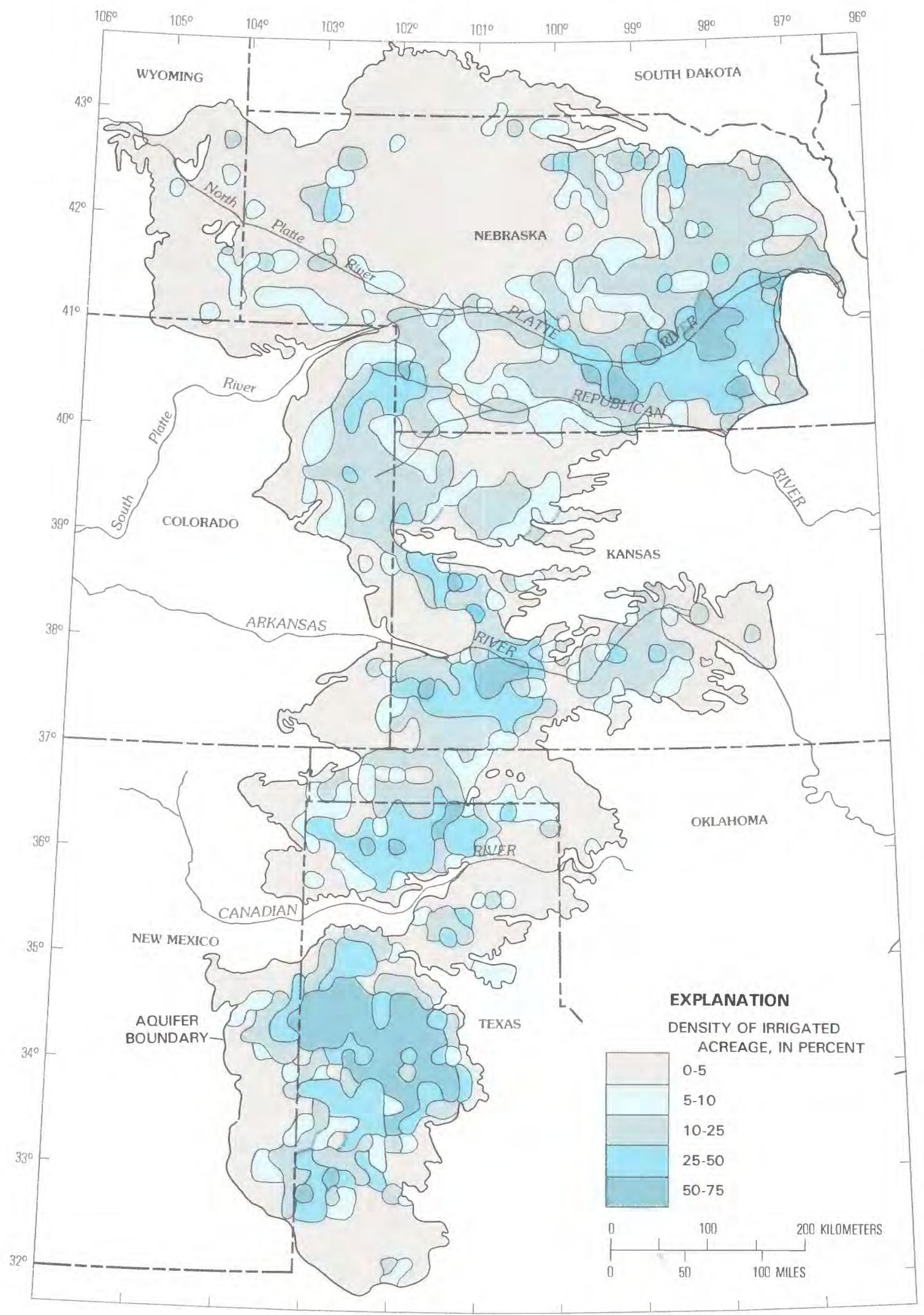

FIGURE 20.-Density of acreage irrigated by ground water in the High Plains, 1978. 
Pabst, 1975). Comparison of figures 18 and 19 shows the increase and northern migration of irrigation in the High Plains, especially in northern Texas, Oklahoma, western Kansas, and parts of Nebraska.

The development of center-pivot irrigation systems during the 1960 's, which were adapted to sandy soils and rolling terrain, made land available for irrigation that previously was not suitable. The increase in irrigated acreage in the northern parts of the High Plains (fig. 20) was mainly the result of center-pivot development. During 1978, an estimated 2,190,000 acres of cropland were irrigated by center-pivot systems in Nebraska (Bittinger and Green, 1980); this was nearly 50 percent of the total acreage irrigated by ground water in Nebraska.

The growth of irrigated cropland in the High Plains based on Census of Agriculture data from 1949-78 is shown in figure 21. In the Texas High Plains, the graph shows rapid increase of irrigated acreage until 1959 followed by a decrease in the growth rate in recent years. The decrease is primarily the result of declining water availability in many areas of the Texas High Plains (Luckey and others, 1981). In contrast to Texas, the graph for the Nebraska High Plains shows a slow rate of increase in early years and a rapid increase in irri-

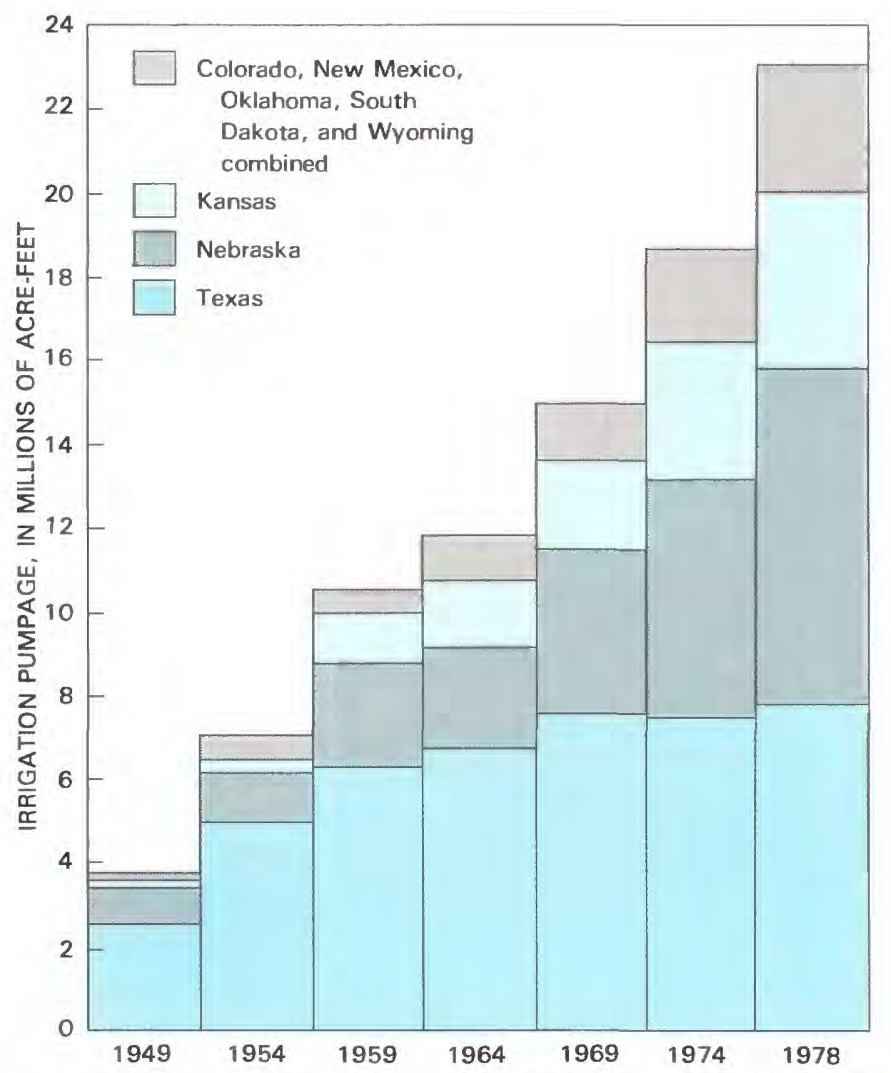

Figure 21.-Acreage irrigated by ground water in the High Plains, 1949-78. gated acreage in recent years. The growth of irrigated acreage in Nebraska is continuing, primarily because of the availability of large quantities of ground water underlying the sand-dune areas that are suitable for irrigation with center-pivot systems. Although the rate of growth has decreased in some parts of the High Plains, it has increased in other areas. The total acreage irrigated by ground water in the High Plains increased from slightly more than 2 million acres in 1949 to about 13 million acres in 1978 . This rapid increase in irrigated acreage in the High Plains has resulted in a corresponding increase in ground-water pumpage and water-level decline.

Estimates of ground-water pumpage were made, using crop consumptive-use data, climatic data, irrigated acreage, and irrigation efficiency estimates. Heimes and Luckey (1982, table 2) estimated historical irrigation requirement for the High Plains using normal-year climatic data. Pumpage can be estimated by adjusting irrigation requirement for efficiency of the irrigation system; efficiency is the ratio of the water pumped to the water required by the crop in addition to precipitation (irrigation requirement).

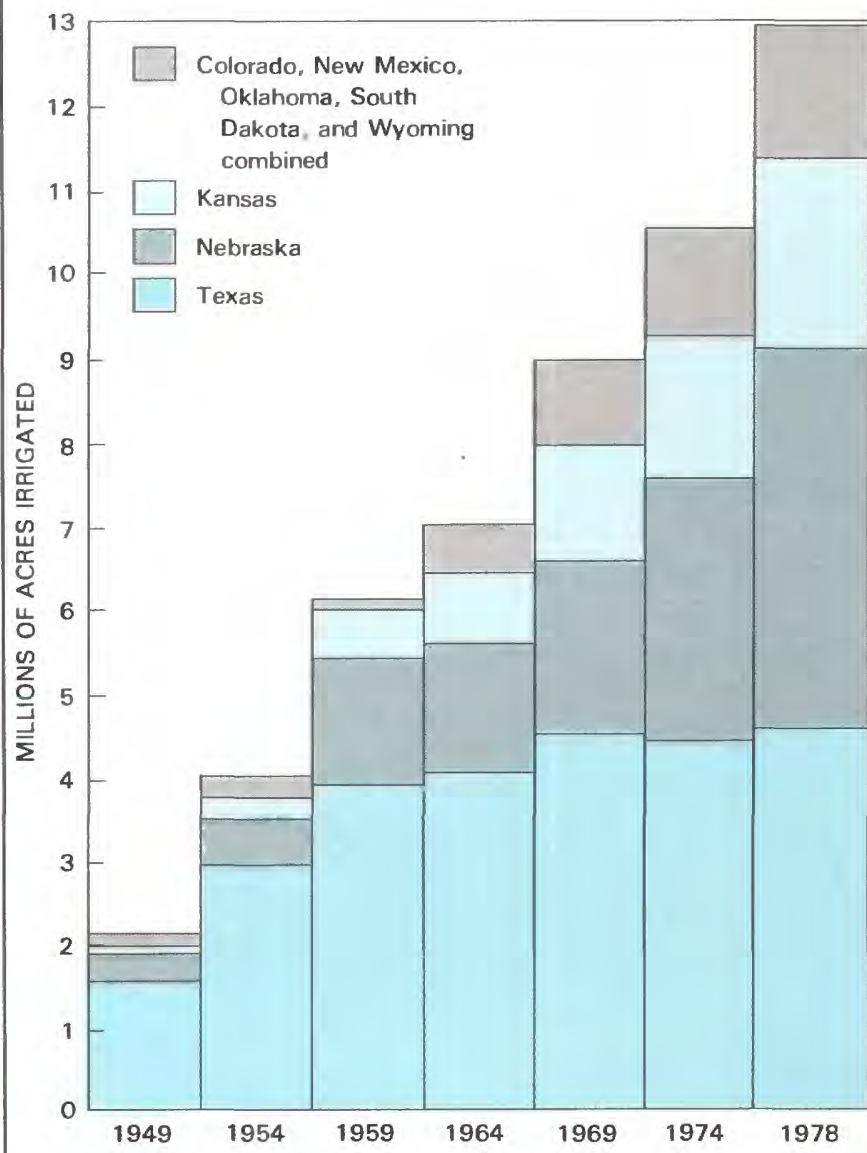

FIGURE 22.-Estimated ground-water pumpage from the High Plains aquifer, 1949-78. 
Ground-water pumpage in the High Plains, estimated by the above procedure for 1949-78, is shown in figure 22 . These pumpage estimates are subject to error because of uncertainty in the data used to compute the estimates. The irrigated acreage used in the calculations was obtained from the Census of Agriculture and adjusted to reflect ground-water irrigated acreage only. Irrigation demand was calculated by using the procedures outlined by the U.S. Department of Agriculture (1967), based on long-term average climatic data. An average system efficiency of 65 percent was assumed for the calculation of pumpage presented in figure 22 . System efficiency generally ranges from about 40 to 90 percent and depends on many factors, such as type of irrigation system, crop type, soil, and climate.

A dramatic increase in pumpage during the last 30 years is shown by figure 22. Pumpage from the High Plains aquifer for irrigation during 1978 was estimated at approximately 23 million acre-ft which is almost 20 million acre-ft more than the estimated pumpage for irrigation during 1949.

\section{EFFECTS OF DEVELOPMENT}

Irrigation demand for crops grown in the High Plains generally is much larger than recharge from precipitation. As previously discussed, natural recharge from precipitation in the High Plains is equivalent to only a small fraction of total precipitation. Estimates of natural recharge (table 7) range from 0.024 inch per year ( 0.1 percent of mean annual precipitation) for parts of the southern High Plains of Texas to 5 inches per year (22 percent of the mean annual precipitation) for the sand hills in Holt County, Nebraska. Irrigation demand for most crops commonly grown in the High Plains is more than 1 foot per year, with the greatest demands occurring in the southern part and the least demands occurring in the northeastern part. The ratio between irrigation demand by crops and natural rate of recharge to the aquifer could be as small as 2 for crops requiring little water in areas with significant recharge and 100 or more for crops requiring significant water in areas with little recharge. Consequently, pumpage for irrigation in large parts of the High Plains greatly exceeds the rate of natural replenishment. Any long-term withdrawal of water from the aquifer that greatly exceeds the recharge rate will result in long-term water-level declines.

The areal extent of water-level declines from predevelopment to 1980 caused by ground-water pumpage is shown in figure 23; this figure was modified from one published at a larger scale by Luckey and others (1981). Water-level declines have occurred in all States except South Dakota, where development, relative to the other States, is sparse. Areas of decline in excess of 100 feet occur in 2,500 mi in parts of Kansas, New Mexico, Oklahoma, and Texas, with most of the area occurring in Texas, south of the Canadian River. Areas of decline in excess of 50 feet from predevelopment to 1980 have occurred in $12,000 \mathrm{mi}^{2}$ in parts of Colorado as well as the States mentioned above. Almost all declines in excess of 50 feet have occurred in the part of the High Plains aquifer south of $39^{\circ}$ latitude. Water levels have declined more than 10 feet in $50,000 \mathrm{mi}^{2}$ of the High Plains aquifer. Large areas in figure 23 show no significant change in water levels $(+10$ to -10 feet of change); some areas show significant rises. Rises in Nebraska are due to recharge from surface-water irrigation; rises in the other States are due to either land-use changes or recovery from abnormally low water levels resulting from the drought of 1933-40.

Water-level changes from predevelopment to 1980 are summarized in table 11, which shows that the High Plains aquifer has had a net depletion caused by pumpage of 166 million acre-ft of water. This is about 5 percent of the predevelopment volume of drainable water stored in the aquifer (table 8). About 70 percent of this depletion has occurred in Texas (114 million acre-ft); 16 percent of the depletion has occurred in Kansas (29 million acre-ft). Nebraska has had significant areas of decline, but the volume of water depleted nearly has been balanced by the volume added in areas of water-level rise (fig. 23) caused by irrigation with water from streams.

The ratio of the volume of drainable water remaining to the volume of water depleted by 1980 can be calculated by using tables 8 and 11. Texas, the State with greatest depletion, still has 3.4 times as much water remaining in the aquifer as has been removed from the aquifer. For the High Plains as a whole, about 19 times as much water remains as has been removed. However, in local areas, the volume of water remaining in the aquifer is less than the volume that has been removed. Luckey and others (1981) showed that more than 50 percent of the original saturated thickness has been dewatered in parts of southwestern Kansas and the southern High Plains of New Mexico and Texas.

The areas of greatest water-level decline shown in figure 23 occur where irrigation first developed, and the volume of water withdrawn from the aquifer since predevelopment is greatest. By comparing the irrigated-acreage density maps (figs. 18, 19, and 20) and the water-level change map (fig. 23), it is apparent that the greatest water-level declines have occurred in those parts of Texas, Oklahoma, and Kansas where irrigation developed earliest. The 1978 irrigated-acreage density map (fig. 20) also shows areas where irrigation was started during the last 2 decades. Water-level declines 


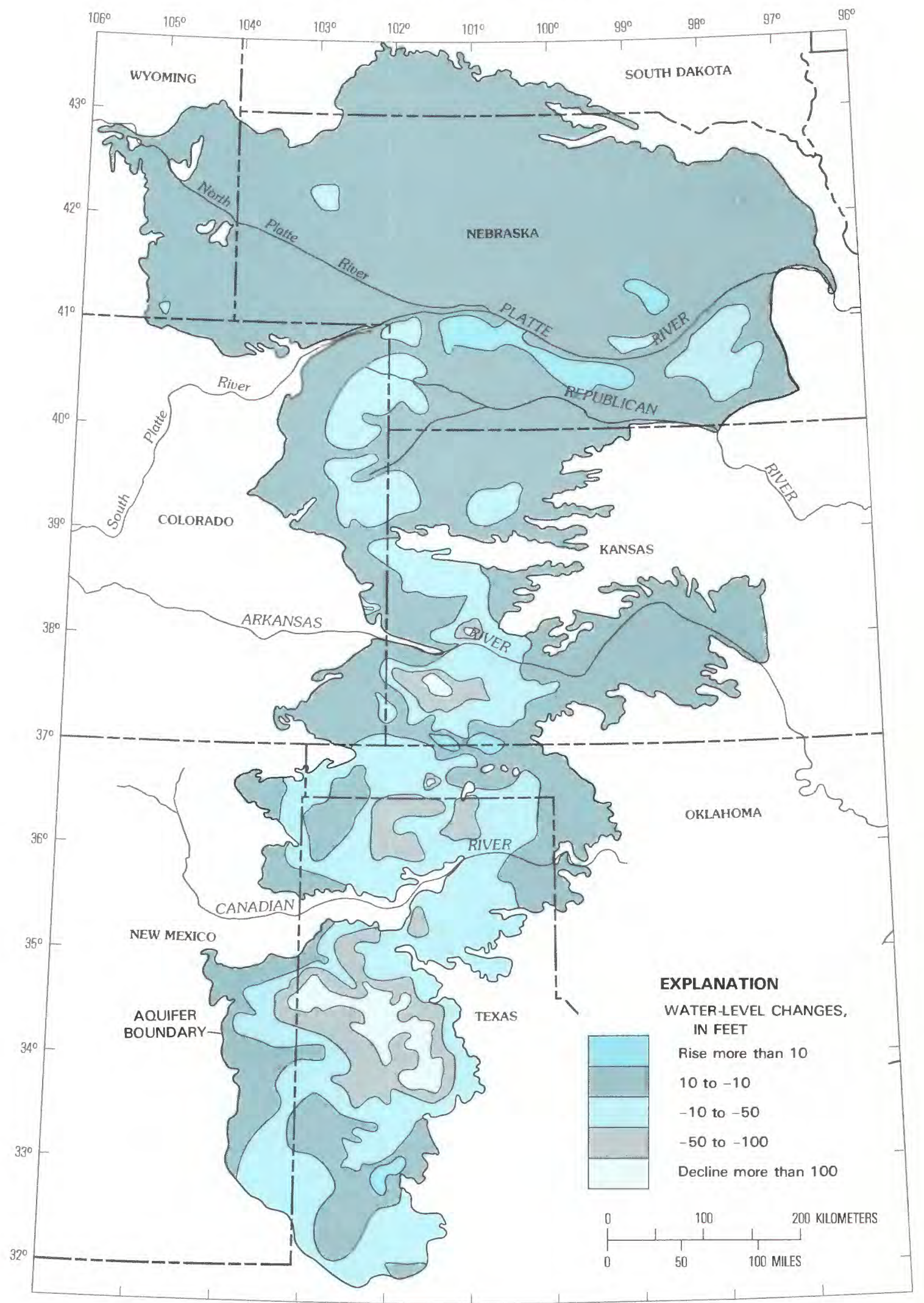

FIGURE 23.-Predevelopment to 1980 water-level changes in the High Plains aquifer (modified from Luckey and others, 1981). 
GEOHYDROLOGY OF THE HIGH PLAINS AQUIFER

TABLE 11.-Distribution of water-level changes and volume of aquifer dewatered, High Plains aquifer, predevelopment to 1980

[Modified from Luckey and others, 1981]

\begin{tabular}{|c|c|c|c|c|c|c|c|c|c|c|}
\hline \multirow[b]{2}{*}{ State } & \multirow{2}{*}{$\begin{array}{c}\text { Area of } \\
\text { High Plains } \\
\text { aquifer } \\
\text { within State } \\
\text { (square miles) }\end{array}$} & \multicolumn{8}{|c|}{ Percentage of area within each water-level change interval } & \multirow{2}{*}{$\begin{array}{l}\text { Volume of } \\
\text { aquifer } \\
\text { dewatered } \\
\text { (millions of } \\
\text { acre-feet) }\end{array}$} \\
\hline & & $\begin{array}{l}\text { More than } \\
50 \text {-foot } \\
\text { rise }\end{array}$ & $\begin{array}{r}+50 \\
\text { to } \\
+25\end{array}$ & $\begin{array}{r}+25 \\
\text { to } \\
+10\end{array}$ & $\begin{array}{r}+10 \\
\text { to } \\
-10\end{array}$ & $\begin{array}{r}-10 \\
\text { to } \\
-25\end{array}$ & $\begin{array}{r}-25 \\
\text { to } \\
-50\end{array}$ & $\begin{array}{r}-50 \\
\text { to } \\
-100\end{array}$ & $\begin{array}{l}\text { More than } \\
100-\text { foot } \\
\text { decline }\end{array}$ & \\
\hline Colorado--..- & 14,900 & - & - & - & 78 & 19 & 3 & -- & - & 6 \\
\hline Kansas---.-- & 30,500 & - & - & 1 & 72 & 11 & 11 & 4 & 1 & 29 \\
\hline Nebraska-.... & $\cdots \quad 63,650$ & 1 & 1 & 2 & 90 & 5 & 1 & -- & - & -- \\
\hline New Mexico--- & 9,450 & - & - & - & 62 & 23 & 11 & 4 & - & 9 \\
\hline Oklahoma-- & 7,350 & - & - & 3 & 56 & 29 & 10 & 2 & - & 8 \\
\hline South Dakota- & 4,750 & - & - & - & 100 & -- & - & -- & - & $\cdots$ \\
\hline Texas- - & 35,450 & - & - & 1 & 23 & 34 & 17 & 18 & 7 & 114 \\
\hline Wyoming & 8,000 & - & - & - & 99 & 1 & - & -- & - & $\cdots$ \\
\hline Total----- & $\cdots 174,050$ & - & - & 1 & 70 & 15 & 7 & 5 & 2 & 166 \\
\hline
\end{tabular}

in these areas are less, because pumpage began later and the total volume of water withdrawn is smaller. This is most evident in Colorado, northwestern Kansas, and Nebraska (compare figs. 19 and 23).

\section{CONSTRAINTS ON DEVELOPMENT}

Water-level declines, decreased well yields, and the distribution of saturated aquifer material have limited development of the ground-water resource in parts of the High Plains. However, other factors, including physical, chemical, economic, and legal constraints limit the areas in which the aquifer has been (and can be) developed.

Historically, topography and soils were the principal constraints on irrigation development. More recently, water-level declines causing decreased well yields and larger pumping lifts have made well yields and economics important constraints. In the future, it is likely that continued water-level declines will cause well yields and economics to become more important factors.

The physical characterisitics of the aquifer constrain further irrigation development in the High Plains by limiting the well yield. The exact pumping rate required to irrigate a specific number of acres will depend on the crop and soil type, climate, and irrigation system. Typically, one well capable of producing $250 \mathrm{gal} /$ min can irrigate 40 acres; one well capable of producing $750 \mathrm{gal} / \mathrm{min}$ can irrigate 160 acres and effectively operate a quarter-section center-pivot system. Of course, it is possible to use several wells operated as a unit to obtain the desired yield. But, at some point, well yields will become a constraint to irrigation development because of the costs associated with drilling, operating, and maintaining additional wells.
A generalized map of potential well yields from the High Plains aquifer is shown in figure 24. The map is based on the 1980 saturated thickness (fig. 9) and hydraulic conductivity (fig. 10) of the aquifer. Potential yield was estimated by assuming that drawdown in the aquifer was limited to 70 percent of the saturated thickness.

The map shows that wells yielding more than 750 $\mathrm{gal} / \mathrm{min}$ generally can be obtained throughout large areas of the High Plains; most noticeable of these areas are large parts of Nebraska and Wyoming and much of the area in southwestern Kansas, Oklahoma, and northern Texas. Only wells yielding less than $250 \mathrm{gal} /$ $\mathrm{min}$ generally can be obtained near the western edge of the aquifer and in large parts of Colorado, northwestern Kansas, New Mexico, and the southern High Plains of Texas. Depending on crop water demand and area to be irrigated, limited well yields may constrain irrigation development in the areas where well yields are less than $250 \mathrm{gal} / \mathrm{min}$ (fig. 24).

Comparison of the potential-yield map (fig. 24) to the 1978 irrigated-acreage-density map (fig. 20) shows that well yields are not yet a limiting factor in most of the area that was irrigated extensively during 1980 . However, there are notable areas, particularly in the southern High Plains, where only wells yielding less than $250 \mathrm{gal} / \mathrm{min}$ can now be obtained in highly developed areas. Greater yielding wells could be obtained in these areas, prior to severe water-level declines.

As well yields decreased, irrigators compensated by drilling more wells or irrigating less acreage. For example, the average number of acres irrigated per well in Castro, Crosby, Floyd, Hale, Lubbock, Parmer, and Swisher Counties, Texas, decreased from 118 in 1958 to 62 in 1980 (Luckey and others, 1981). This decrease 


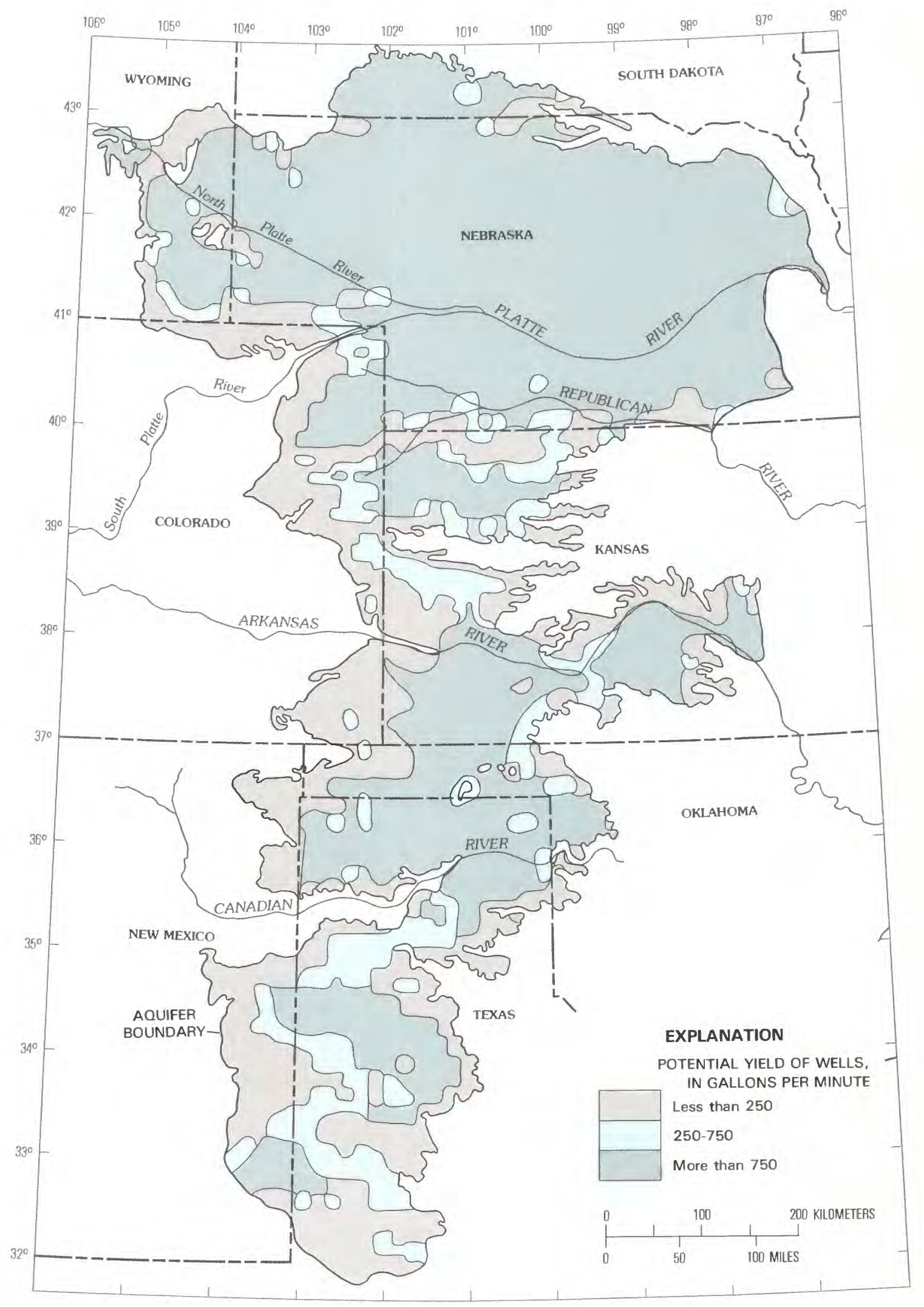

Figure 24.-Potential well yields from the High Plains aquifer, 1980. 
in acres irrigated per well is the result of decreasing well yields, caused by declining water levels and decreasing saturated thickness in the aquifer. From 1958 to 1980 , the number of irrigated acres in the seven counties decreased from 2.5 million to 1.9 million, and the number of wells increased from about 21,000 to 30,000 . Declining well yields and increased pumping lifts in these seven counties undoubtedly have caused significant increases in farm-operation expenses. Similar impacts can be expected, as ground-water development continues in other areas of the High Plains.

Chemical quality of water in the High Plains aquifer may limit irrigation development in some areas. Although many chemical constituents or properties of water affect its suitability for irrigation, the two main criteria for determining the suitability of water for irrigation are dissolved-solids concentration (salinity hazard) and sodium concentration, relative to calcium and magnesium concentrations (sodium hazard).

Salinity hazard is important because mineralized water can interfere with the process by which plants extract water from the soil. The importance of this hazard is related to irrigation practices and crop type. Two crops commonly grown in the High Plains, alfalfa and sugar beets, are tolerant to salinity, while some kinds of field beans are sensitive to salinity (U.S. Salinity Laboratory Staff, 1954). All other crops commonly grown on the High Plains are semi-tolerant to salinity.

Specific conductance is a convenient measure of the dissolved-solids concentration and salinity hazard of water; specific conductance is the electrical conductivity of water, measured in micromhos per centimeter at $25^{\circ}$ Celsius ( $\mu \mathrm{mho})$. Almost all sources of irrigation water that have been used successfully for a considerable time have specific conductances of less than $2,250 \mu$ mho. Waters with greater specific conductance are used occasionally, but crop production has not been satisfactory, except in unusual situations (U.S. Salinity Laboratory Staff, 1954).

Excessive concentrations of sodium are harmful to plants and soil. Accumulation of sodium in soils affects plant growth and decreases soil permeability and tillability. The sodium hazard is most important in finetextured (clayey) soils (fig. 14). The sodium-adsorption ratio is a means of determining whether the sodium concentration of water is likely to affect soil properties adversely. The U.S. Salinity Laboratory Staff (1954) defined sodium-adsorption ratio (SAR) of water as:

$$
\operatorname{SAR}=\frac{\left(\mathrm{Na}^{+}\right)}{\sqrt{\frac{\left(\mathrm{Ca}^{++}\right)+\left(\mathrm{Mg}^{++}\right)}{2}}}
$$

where ion concentrations are expressed in milliequivalents per liter. Experiments cited by the U.S. Salinity Laboratory show that the SAR predicts reasonably well the degree to which irrigation water tends to enter into cation-exchange reactions in soil. Large SAR values indicate a hazard of sodium replacing adsorbed calcium and magnesium; this replacement is damaging to soil structure (Hem, 1970).

A diagram for the classification of irrigation waters, developed by the U.S. Salinity Laboratory Staff (1954), is shown in figure 25; it is based on the specific conductance and SAR. Chemical analyses of 28 ground-water samples from the High Plains aquifer were presented in table 10; locations of the wells from which these samples were collected are shown in figure 17. The specific conductance and SAR from these samples (table 10) are plotted and identified by number in figure 25 .

The diagram for classification of irrigation waters (fig. 25) shows that 17 of the 28 samples had low- or medium-salinity hazard, and all samples but 2 had lowsodium hazard. Most of the water in the High Plains aquifer has medium-salinity hazard and low-sodium hazard. This type of water can be used for irrigation, if some leaching occurs. Plants with moderate salt tolerances (which include most crops grown in the High Plains) can be grown in most instances without special practices for salinity control; there is little danger of the development of harmful levels of exchangeable sodium.

In a few areas in the High Plains, salinity or sodium hazard could limit further agricultural development. Areas of high- or very high salinity hazard occur in Colorado (sample 14), Kansas (samples 15, 16, 17, and 20), New Mexico (sample 26), Oklahoma (sample 22), Texas (samples 23, 27, and 28), and Wyoming (sample 3). In the vicinity of these samples (fig. 17), water from the High Plains aquifer may not be suitable for irrigation on soils with poor drainage without management for salinity control. In other areas where the concentration of dissolved solids exceeds $1,000 \mathrm{mg} / \mathrm{L}$ (fig. 15), salinity could limit the use of water from the aquifer for irrigation, depending on the type of crops grown, soil type, and management practices. Also, alkaline soils could develop from the use of ground water for irrigation in areas where the concentration of sodium exceeds 100 $\mathrm{mg} / \mathrm{L}$ (fig. 17), depending on soil type, calcium and magnesium concentrations in ground water, and management practices.

Agricultural economics also could be a limiting factor to further irrigation development in the High Plains. Most economic factors, such as crop prices, and energy, land, fertilizer, labor, and equipment costs, are independent of water resources, but the cost of pumping water is related to the depth from which water is 


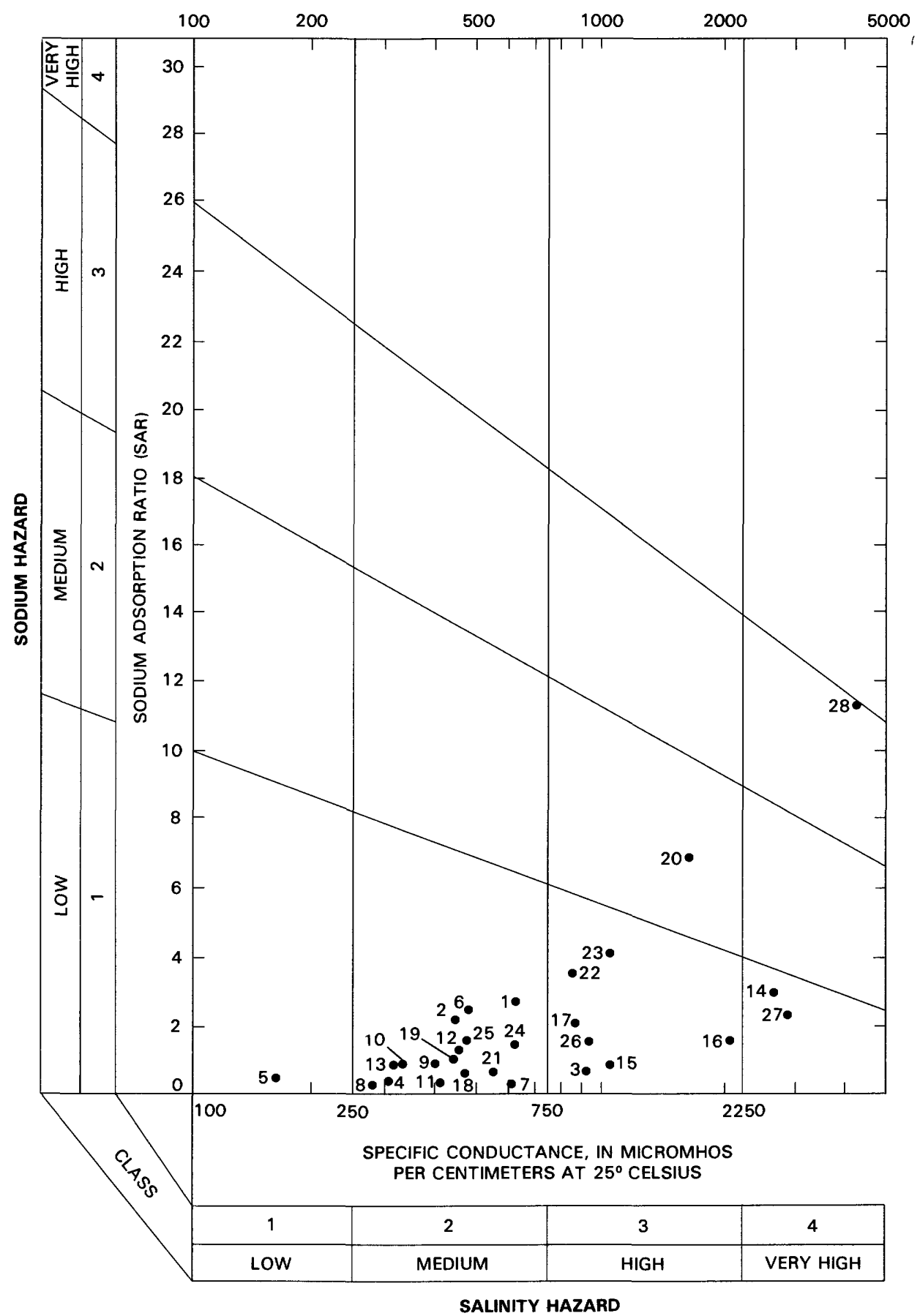

FIGURE 25.-Classification of salinity and sodium hazards for irrigation water (from Krothe and others, 1982).

pumped. The limiting depth from which it is no longer economically feasible to lift irrigation water is not a fixed quantity; it changes as the prices of energy and crops change.

In 1979, energy costs to pump 1 acre-ft of water with 100 feet of lift were $\$ 9.95$ for electricity and $\$ 6.00$ for natural gas (Sloggett, 1981). Based on 1990 projected energy prices (Sloggett, 1981, p. 19), the above costs will double for electricity and increase 6-fold for natural gas. Considering that water levels in the High Plains aquifer are declining (increasing pumping lift), and that energy costs are proportional to lift (doubling lift dou- 
bles cost), depth to water may become an important constraint to future agricultural economics and development.

A generalized map of depth to water in the High Plains aquifer is shown in figure 26. This map was prepared by subtracting the 1980 altitude of the table in the aquifer (fig. 8) from the average altitude of land surface from U.S. Geological Survey topographic maps at approximately 1,800 points and contouring the results. The map is very general and represents only typical depth to water for large areas. In topographically low areas, such as stream valleys or inter-dune areas, depth to water could be considerably less than that shown on the map; in topographically high areas, such as on hills or tops of dunes, depth to water could be considerably greater than that shown on the map. In areas of little or no saturated thickness, the indicated depth to water may be in the bedrock.

The depth-to-water map (fig. 26) shows large areas in Nebraska, Kansas, New Mexico, and Texas, where the depth to water is less than 50 feet. The depth to water is greater than 300 feet in parts of Kansas, New Mexico, and Texas. If all other factors were equal, pumping costs would be 6 times greater where the depth to water is 300 feet than where it is 50 feet. Thus, depending on future energy costs, pumping lifts may constrain agricultural development in those areas of the High Plains where the depth to water is greatest.

In the High Plains, State laws regulate development of ground-water resources as summarized in table 12 . Each of the eight States has developed its own body of law, and these laws vary from State to State. Oklahoma and Texas are the only two States that recognize private ownership of ground water; in the other six States, water is dedicated to the people of the State. In New Mexico and South Dakota, State agencies administer the water. In the other six States, administration is shared to a greater or lesser extent between State and local agencies. This results in varying rules within a State. In all States, a well registration or permitting system exists; and, in several States, there is a limit on the minimum spacing between wells. Other regulations vary between States and may vary within each State. A more detailed discussion is given by Sloggett (1977).

The Colorado Groundwater Commission, directed by the State Engineer, manages ground water in Colorado. The Commission has the authority to designate ground-water basins and approve local ground-water management district boundaries and rules within ground-water basins. In the High Plains, two groundwater basins have been designated, the Northern High
Plains and the Southern High Plains (fig. 27). There are eight operational ground-water management districts in the Northern High Plains basin. Well permits are required Statewide; further restrictions apply in designated ground-water basins (table 12). Groundwater management districts may adopt rules that are more restrictive than Groundwater Commission policy. These districts may determine well spacing requirements, establish depletion rates, limit pumping, require metering, and develop water-conservation measures.

Ground water in Kansas is administered by the Chief Engineer, Division of Water Resources, State Board of Agriculture. Five ground-water management districts have been formed in the High Plains (fig. 27). District management programs are approved by the Chief Engineer. Well permits are required Statewide to establish water rights. Management districts have the authority to adopt and enforce ground-water management policies within existing State laws. Regulations vary among the districts, but restrictions on well spacing, drilling, allocation of water, and wastage have been adopted (table 12). Management policies vary from allowing no depletion of the aquifer to allowing controlled depletion.

In Nebraska, ground water is administered by the Department of Water Resources, ground-water conservation districts, and natural resource districts. Six ground-water conservation districts were formed prior to 1972 , when 24 natural resource districts were established to cover the State. The conservation and natural resource districts share the responsibility and function of ground-water management, where both districts exist. Registration of wells, minimum spacing of 600 feet for irrigation wells and 1,000 feet for municipal and industrial wells, and runoff control are required Statewide (table 12). Control areas can be proposed by natural resource districts and approved by the Division of Water Resources. Control areas are managed by the local natural resource district. In control areas, permits to drill wells are required, and regulations may be established to restrict well spacing, limit allocations, and restrict well drilling. As of 1982 , three control areas had been established (fig. 27) in the Upper Republican, Upper Big Blue, and Little Blue Natural Resource Districts. Beginning in 1982, natural resource districts have the authority to establish managment areas, where well spacing and water allocation may be restricted without approval from the Division of Water Resources.

The State Engineer administers ground water in New Mexico, but only within declared ground-water basins. Ground water outside declared basins is not subject to regulation. Two ground-water basins have 


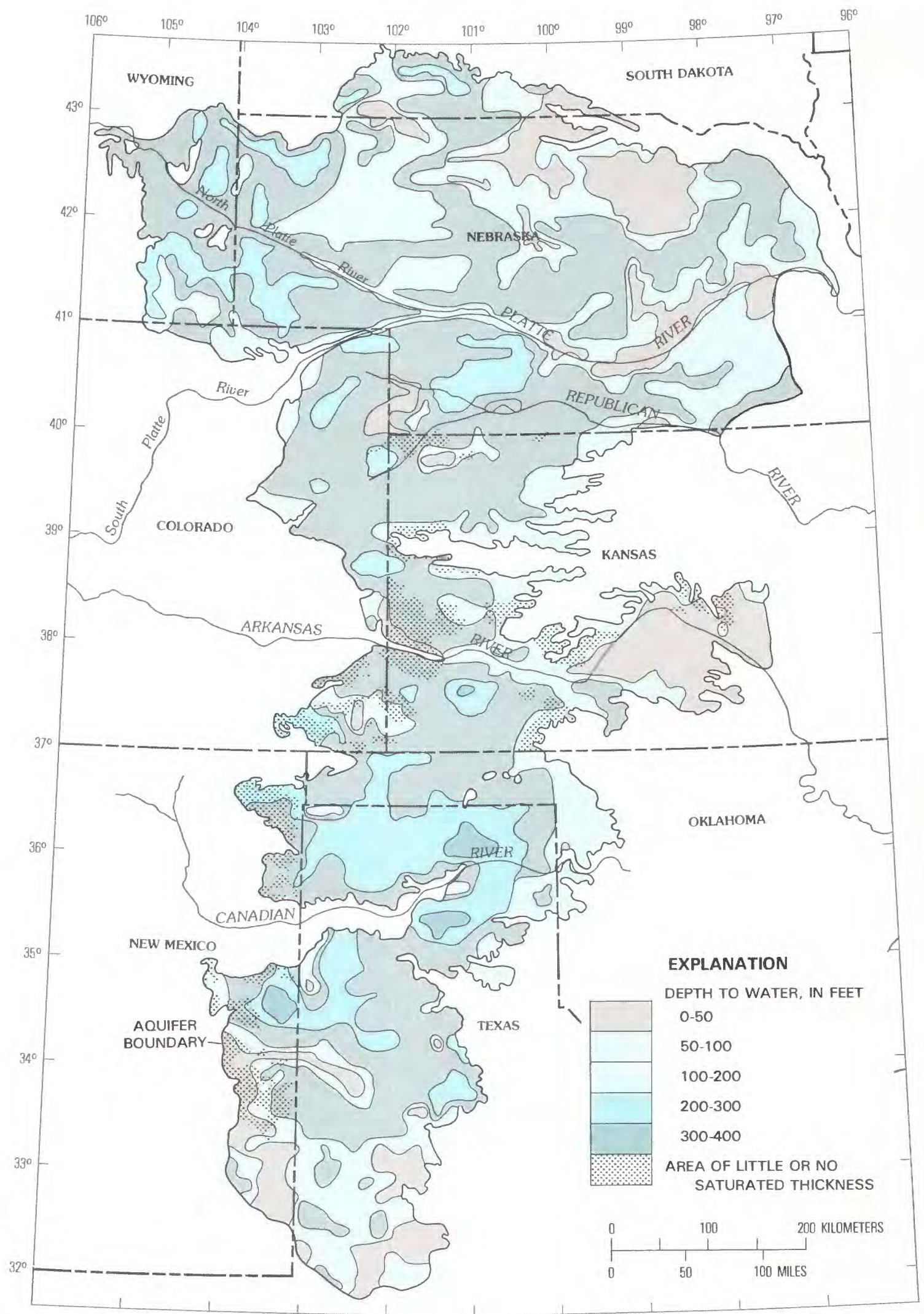

FIGURE 26.-Generalized depth to water in the High Plains aquifer, 1980. 


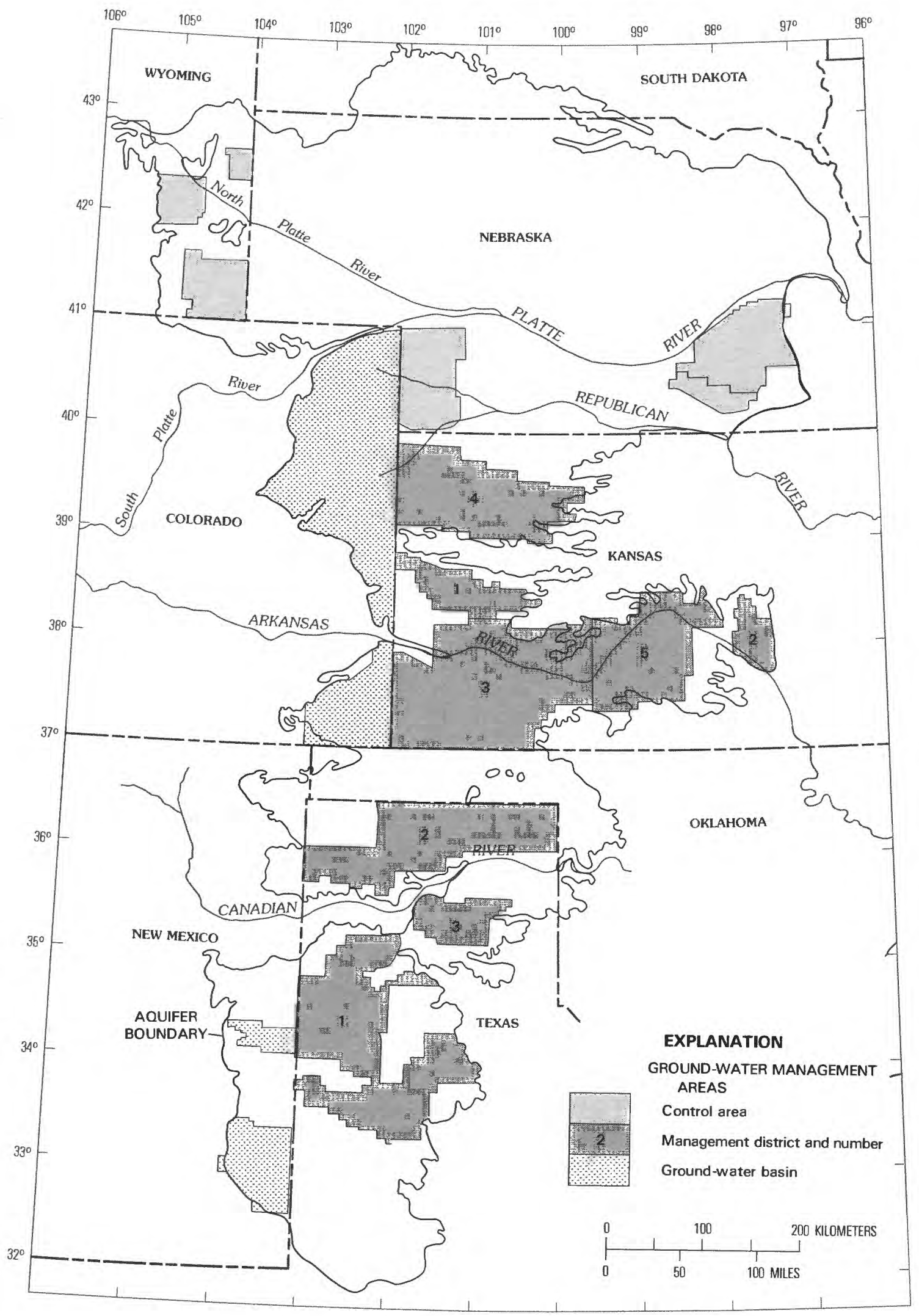

FIGURE 27.-Ground-water management areas in the High Plains. 
TABLE 12.-Summary of regulations controlling ground-water

\begin{tabular}{|c|c|c|c|c|c|c|}
\hline \multirow{3}{*}{ State } & \multicolumn{3}{|c|}{ Control of ground water } & \multicolumn{3}{|r|}{ Regulations } \\
\hline & \multirow{2}{*}{$\begin{array}{l}\text { Owner- } \\
\text { ship }\end{array}$} & \multicolumn{2}{|c|}{ Administering agencies } & \multirow{2}{*}{$\begin{array}{l}\text { Well } \\
\text { permits }\end{array}$} & \multirow{2}{*}{$\begin{array}{l}\text { Flow } \\
\text { metering }\end{array}$} & \multirow{2}{*}{$\begin{array}{c}\text { Minimum well } \\
\text { spacing } \\
\text { (feet) }\end{array}$} \\
\hline & & State & Local & & & \\
\hline Colorado & State & $\begin{array}{l}\text { Groundwater } \\
\text { Commission, } \\
\text { State } \\
\text { Engineer. }\end{array}$ & $\begin{array}{c}\text { Groundwater } \\
\text { Management } \\
\text { Districts. }\end{array}$ & $\begin{array}{l}\text { Required } \\
\text { state- } \\
\text { wide. }\end{array}$ & $\begin{array}{l}\text { Can be } \\
\text { re- } \\
\text { quired. }\end{array}$ & $\begin{array}{l}2,640 \text { in } \\
\text { ground-water } \\
\text { basins. }\end{array}$ \\
\hline Kansas-- & State & $\begin{array}{l}\text { State Board of } \\
\text { Agriculture, } \\
\text { Div. of Water } \\
\text { Resources. }\end{array}$ & $\begin{array}{l}\text { Groundwater } \\
\text { Management } \\
\text { Districts. }\end{array}$ & Required & $\begin{array}{l}\text { Can be } \\
\text { re- } \\
\text { quired. }\end{array}$ & $\begin{array}{l}1,320 \text { to } 2,640 \\
\text { depending on } \\
\text { area and well } \\
\text { yield. }\end{array}$ \\
\hline Nebraska & State & $\begin{array}{l}\text { Department } \\
\text { of Water } \\
\text { Resources. }\end{array}$ & $\begin{array}{l}\text { Groundwater } \\
\text { Conserva- } \\
\text { tion and } \\
\text { Natural } \\
\text { Resources } \\
\text { Districts. }\end{array}$ & $\begin{array}{l}\text { Registra- } \\
\text { tion re- } \\
\text { quired. }\end{array}$ & $\begin{array}{l}\text { In some } \\
\text { areas. }\end{array}$ & $\begin{array}{l}600 \text { to } 1,000 \\
\text { in control } \\
\text { areas. }\end{array}$ \\
\hline $\begin{array}{l}\text { New } \\
\text { Mexico. }\end{array}$ & State & $\begin{array}{l}\text { State } \\
\text { Engineer. }\end{array}$ & None & Required & $\begin{array}{l}\text { In some } \\
\text { areas. }\end{array}$ & None \\
\hline Oklahoma & $\begin{array}{l}\text { Land- } \\
\text { owner. }\end{array}$ & $\begin{array}{l}\text { Water } \\
\text { Resources } \\
\text { Board. }\end{array}$ & $\begin{array}{l}\text { None, but } \\
\text { can be } \\
\text { organized. }\end{array}$ & Required & $\begin{array}{l}\text { None, } \\
\text { but can } \\
\text { be re- } \\
\text { quired. }\end{array}$ & $\begin{array}{l}\text { None, but } \\
\text { can be } \\
\text { required. }\end{array}$ \\
\hline $\begin{array}{l}\text { South } \\
\text { Dakota. }\end{array}$ & State & $\begin{array}{l}\text { Dept. of Water } \\
\text { and Natural } \\
\text { Resources. }\end{array}$ & None & Required & None & None \\
\hline Texas--- & $\begin{array}{l}\text { Land- } \\
\text { owner. }\end{array}$ & $\begin{array}{l}\text { Dept. of Water } \\
\text { Resources. }\end{array}$ & $\begin{array}{l}\text { Groundwater } \\
\text { Management } \\
\text { Districts. }\end{array}$ & Required & None & $\begin{array}{l}600 \text { to } 1,200 \\
\text { depending on } \\
\text { well size } \\
\text { and yield. }\end{array}$ \\
\hline Wyoming- & State & $\begin{array}{l}\text { Board of Con- } \\
\text { trol, State } \\
\text { Engineer. }\end{array}$ & $\begin{array}{l}\text { Advisory } \\
\text { board. }\end{array}$ & $\begin{array}{l}\text { Required } \\
\text { state- } \\
\text { wide. }\end{array}$ & None & None \\
\hline
\end{tabular}

been declared in the High Plains of New Mexico (fig. 27)-part of Lea County since 1931 and the Portales Valley in Roosevelt County since 1950. Within the declared basins, the State Engineer restricts drilling and limits allocation of water based on planned depletion of the ground-water supply in 40 years, beginning in 1952 for Lea County and 1956 for Portales Valley. Water-use permits, when authorized, are limited to 3 acre-ft per acre per year (table 12).

Ground water in Oklahoma belongs to the landowner but is administered by the Water Resources Board. Oklahoma ground-water law provides for the formation of ground-water management districts, but none have been formed as of 1982. The Water Resources Board has the authority to regulate the allocation of ground water, require metering of wells if the majority of the landowners concur, and specify minimum well spacing. As of 1982 , only allocations have been regulated by the Board. Allocations are based on planned depletion of the aquifer no sooner than 1993 (table 12). When applications for new wells would cause depletion before 1993, no new water-use permits will be allowed.

Ground water in South Dakota is administered by the Department of Water and Natural Resources. 
development from the High Plains aquifer, by State

\begin{tabular}{|c|c|c|c|c|}
\hline \multicolumn{4}{|c|}{ affecting ground-water development } & \multirow[b]{2}{*}{ Remarks } \\
\hline $\begin{array}{l}\text { Drilling } \\
\text { restrictions }\end{array}$ & $\begin{array}{c}\text { Limited } \\
\text { allocation } \\
\text { (acre-feet per } \\
\text { acre per year) }\end{array}$ & $\begin{array}{l}\text { Planned rate } \\
\text { of depletion }\end{array}$ & $\begin{array}{l}\text { Conservation } \\
\text { measures }\end{array}$ & \\
\hline $\begin{array}{l}\text { In areas of } \\
\text { planned rate } \\
\text { of depletion. }\end{array}$ & $\begin{array}{l}2.5 \text { in N. High } \\
\text { Plains, } 3.5 \text { in } \\
\text { S. High Plains. }\end{array}$ & $\begin{array}{l}40 \text { percent in } \\
25 \text { years in } N . \\
\text { High Plains, } \\
\text { none in S. } \\
\text { High Plains. }\end{array}$ & $\begin{array}{l}\text { Can be } \\
\text { required. }\end{array}$ & $\begin{array}{l}\text { Most regulations } \\
\text { only apply to } \\
\text { designated } \\
\text { ground-water } \\
\text { basins. }\end{array}$ \\
\hline $\begin{array}{l}\text { Restricted in } \\
\text { some areas. }\end{array}$ & $\begin{array}{l}1.5 \text { to } 2.0 \\
\text { depending on } \\
\text { location. }\end{array}$ & $\begin{array}{l}\text { Varies by } \\
\text { management } \\
\text { district. }\end{array}$ & Required & $\begin{array}{l}\text { Rules vary by } \\
\text { management } \\
\text { district. }\end{array}$ \\
\hline $\begin{array}{l}\text { Permit re- } \\
\text { quired in } \\
\text { control } \\
\text { areas. }\end{array}$ & $\begin{array}{l}\text { Varies by } \\
\text { control area. }\end{array}$ & None & $\begin{array}{l}\text { Statewide } \\
\text { irrigation- } \\
\text { runoff } \\
\text { control. }\end{array}$ & $\begin{array}{l}\text { Rules vary by } \\
\text { conservation } \\
\text { and natural } \\
\text { resources } \\
\text { district. }\end{array}$ \\
\hline $\begin{array}{l}\text { Restricted } \\
\text { in declared } \\
\text { ground-water } \\
\text { basins. }\end{array}$ & 3.0 & $\begin{array}{l}\text { Not sooner } \\
\text { than } 40 \text { years } \\
\text { starting in } \\
1952 \text { or } 1956 .\end{array}$ & $\begin{array}{l}\text { Waste is not } \\
\text { allowed. }\end{array}$ & $\begin{array}{l}\text { Regulations } \\
\text { only apply to } \\
\text { declared ground- } \\
\text { water basins. }\end{array}$ \\
\hline None & $\begin{array}{l}\text { Temporary per- } \\
\text { mits for } 2, \\
\text { permanent } \\
\text { permits based } \\
\text { on supply. }\end{array}$ & $\begin{array}{c}\text { Not sooner } \\
\text { than } 1993 .\end{array}$ & $\begin{array}{l}\text { Waste is not } \\
\text { allowed. }\end{array}$ & $\begin{array}{l}\text { Regulation began } \\
\text { in } 1973 \text {, only } \\
\text { well permits and } \\
\text { allocations con- } \\
\text { trolled in } 1982 .\end{array}$ \\
\hline None & 2 maximum & $\begin{array}{l}\text { Allocation lim- } \\
\text { ited to rate } \\
\text { of recharge; } \\
\text { depletion not } \\
\text { allowed. }\end{array}$ & $\begin{array}{l}\text { Waste is not } \\
\text { allowed. }\end{array}$ & $\begin{array}{l}\text { Regulations do } \\
\text { not apply to } \\
\text { Indian reser- } \\
\text { vations. }\end{array}$ \\
\hline $\begin{array}{l}\text { Restricted } \\
\text { in certain } \\
\text { areas. }\end{array}$ & $\begin{array}{c}\text { None, but can } \\
\text { be limited. }\end{array}$ & None & $\begin{array}{l}\text { Waste is not } \\
\text { allowed. }\end{array}$ & $\begin{array}{l}\text { Rules only apply } \\
\text { in management } \\
\text { districts. }\end{array}$ \\
\hline $\begin{array}{l}\text { Permit } \\
\text { required. }\end{array}$ & $\begin{array}{l}\text { Restricted } \\
\text { in control } \\
\text { areas. }\end{array}$ & None & $\begin{array}{l}\text { Waste is not } \\
\text { allowed. }\end{array}$ & $\begin{array}{l}\text { Restrictions } \\
\text { apply to con- } \\
\text { trol areas. }\end{array}$ \\
\hline
\end{tabular}

There are no ground-water management districts in South Dakota. Permits are required for irrigation wells and allocations are limited to the recharge rate, as determined by the Department, in the area to be irrigated. Depletion of ground water is not allowed, and annual allocations cannot exceed 2 acre-ft per acre irrigated (table 12). There are no specific restrictions on well spacing or drilling, and metering is not required. However, if problems related to ground-water development occur in an area, the Department has the authority to declare a critical water-control area and restrict further development. As of 1982, there were no control areas in South Dakota. The regulations do not apply to Indian reservations.

In Texas, ground water is owned and controlled by the landowner. The Texas Department of Water Resources is the principal State agency with water-resource planning functions. However, Department ground-water activities are limited to fact finding, data collection, and analysis of ground-water supplies. The Department has no control over well drilling or allocation of ground water. Ground-water management is the option of the people, who can establish ground-water management districts by vote under the local-option 
ground-water control law of 1949. As of 1982, three ground-water management districts have been formed in the High Plains of Texas (fig. 27). These three districts have the authority to require permits, limit well spacing, restrict allocations, and prohibit waste. As of 1982 , the districts have exercised all their authority except limiting water-use allocations (table 12). There are no restrictions on irrigation wells outside the management districts.

Ground water in Wyoming is administered by the State Engineer and the State Board of Control. A permit must be obtained from the State Engineer before a well can be drilled in Wyoming. The permit usually is granted, except in control areas. In areas of groundwater supply or use problems, the State Engineer may recommend to the State Board of Control that a control area be established. Upon approval of the Board, a control area advisory board is elected from the local people. With the advice of the advisory board, the State Engineer establishes the regulations necessary to alleviate the ground-water problem (table 12). As of 1982, there were three control areas in the High Plains of Wyoming in Laramie, Goshen, and Platte Counties (fig. 27). Within control areas, applications to drill wells and use ground water (for other than stock or domestic wells under $25 \mathrm{gal} / \mathrm{min}$ ) must be approved by the advisory board. If the board approves, the application is advertised for public comment. If there are public protests, a hearing is held, before the State Engineer decides on the application.

Management of ground water, as well as other resources, is necessary to obtain the greatest benefit for the most people in the High Plains. This can be obtained only through orderly development. The regulations summarized in table 11 attempt to control development and manage the resource within the policies and legal structure of each State. Future development of the High Plains aquifer will be controlled by the laws of each State.

\section{SUMMARY AND CONCLUSIONS}

The High Plains aquifer underlies about $174,000 \mathrm{mi}^{2}$ in parts of eight States-Colorado, Kansas, Nebraska, New Mexico, Oklahoma, South Dakota, Texas, and Wyoming. The aquifer is the principal source of water in one of the Nation's major agricultural areas. About 170,000 wells pump water from the aquifer to irrigate about 13 million acres in the High Plains.

The High Plains aquifer consists of hydraulically connected geologic units of late Tertiary or Quaternary age. The upper Tertiary rocks include part of the Brule Formation, Arikaree Group, and Ogallala Formation.
The Quaternary rocks consist of alluvial, dune-sand, and valley-fill deposits.

The Brule Formation is predominately a massive siltstone with little permeability. In areas where the permeability of the formation has been increased by joints or fractures, the Brule is included in the High Plains aquifer. Where joints and fractures have not enhanced the permeability of the unit, the top of the Brule Formation is considered the base of the aquifer. The Brule Formation is included in the aquifer in parts of Colorado, Nebraska, and Wyoming.

The Arikaree Group (or Formation) includes all upper Tertiary rocks between the underlying Brule Formation and the overlying Ogallala Formation. The Arikaree crops out in, or underlies parts of, western Nebraska, southwestern South Dakota, southeastern Wyoming, and northeastern Colorado. The Arikaree is predominantly a massive sandstone, with thickness as much as 1,000 feet in Wyoming and western Nebraska.

The Ogallala Formation, which underlies $134,000 \mathrm{mi}^{2}$, is the principal geologic unit in the High Plains aquifer. The Ogallala consists of a heterogeneous sequence of clays, silts, sands, and gravels, deposited by streams that flowed eastward from the mountains. Within the Ogallala, zones cemented with calcium carbonate are resistant to weathering and form escarpments that typically mark the boundary of the High Plains.

Unconsolidated alluvial deposits of Quaternary age in hydraulic connection with Tertiary deposits are part of the High Plains aquifer. Much of the gravel, sand, silt, and clay in the alluvial deposits are reworked from the Ogallala Formation. Alluvial deposits comprise the High Plains aquifer in south-central Nebraska and the Great Bend area in central Kansas. In many parts of the High Plains, Quaternary alluvial deposits directly overlie the Ogallala Formation to form one aquifer.

Dune-sand deposits of Quaternary age, consisting predominantly of very fine to medium wind-blown sand, are part of the High Plains aquifer. The most extensive area of dune sand is in west-central Nebraska, where the deposits cover an area of about $20,000 \mathrm{mi}^{2}$. Large = areas also are covered by dune-sand deposits south of the Arkansas River in Kansas. In south-central Kansas, dune sand is saturated in many places and forms part of the aquifer system. In southwestern Kansas, the water table generally lies below the dune-sand deposits which are recharge areas for the underlying alluvial deposits and Ogallala Formation. Recharge areas also occur in other parts of the study area where dune sand overlies the High Plains aquifer.

Valley-fill deposits consist of unconsolidated gravel, sand, silt, and clay, associated with the most recent cycle of erosion and deposition along present streams. 
Valley-fill deposits that are hydraulically connected to underlying Tertiary or Quaternary deposits are part of the High Plains aquifer. The valley-fill deposits and associated streams form stream-aquifer systems that link the High Plains aquifer to surface streams, particularly along the Platte and Arkansas Rivers.

The bedrock in contact with the High Plains aquifer ranges in age from Permian to Tertiary. Geologic units comprising the High Plains aquifer primarily were deposited on an erosional surface cut into the bedrock units.

Permian rocks underlie 12 percent of the High Plains aquifer in Kansas, Oklahoma, and Texas. Dissolution of Permian evaporites by ground water has resulted in faulting of the overlying deposits. Bear Creek fault in Kansas and Colorado and Crooked Creek fault in Kansas and Oklahoma are the result of salt dissolution. In many areas, collapse structures in the Permian rocks are filled by younger material that is part of the High Plains aquifer.

Rocks of Triassic and Jurassic age directly underlie 16 percent of the High Plains aquifer in Colorado, Kansas, New Mexico, Oklahoma, and Texas. Some sandstones of Triassic and Jurassic age have adequate permeability to yield large enough quantities of water for irrigation. Between the Arkansas and Canadian Rivers in parts of Colorado, Kansas, Oklahoma, New Mexico, and Texas, many irrigation wells withdraw water from both the High Plains aquifer and Triassic and Jurassic sandstones.

Lower Cretaceous rocks directly underlie 12 percent of the High Plains aquifer in parts of Colorado, Kansas, Nebraska, New Mexico, Oklahoma, and Texas. Where Lower Cretaceous sandstone beds are in contact with overlying younger deposits in the High Plains aquifer, hydraulic connection occurs between the two units. These sandstones typically have little permeability and storage relative to the High Plains aquifer.

Upper Cretaceous rocks directly underlie 32 percent of the High Plains aquifer in large areas in Colorado, Kansas, and Nebraska and small areas in New Mexico, South Dakota, and Wyoming. Except for the Niobrara Chalk, Upper Cretaceous rocks generally do yield significant quantities of water to wells.

Oligocene rocks directly underlie 28 percent of the High Plains aquifer in Colorado, Nebraska, South Dakota, and Wyoming. The White River Group of Oligocene age is the oldest Tertiary deposit present under the High Plains. The Chadron and Brule Formations comprise the White River Group. The Chadron Formation is the lower unit and mainly consists of consolidated beds of clay and silt. The Brule Formation is predominately a massive siltstone. The sediments com- prising the Brule Formation were deposited in a large basin that contained freshwater lakes, mud flats, and braided streams. The upper part of the Brule Formation is part of the High Plains aquifer in areas where it contains secondary permeability resulting from interconnected fractures.

Faulting and salt dissolution have affected the bedrock surface and thickness of the High Plains aquifer. Along the Wheatland fault in Wyoming, the bedrock has been displaced as much as 1,000 feet, and much of the Tertiary-fill material on the downthrown side is part of the High Plains aquifer. In South Dakota, the White Clay fault has caused about 500 feet of displacement in the bedrock.

Faulting and collapse structures associated with salt dissolution in Permian bedrock occur from the Arkansas River drainage in Colorado and Kansas to the Colorado River drainage in Texas. Permian salt deposits are being dissolved by circulating water that flows from the bedrock through the High Plains aquifer or bedrock units to discharge to streams. Water from the bedrock units affects the quality of water in the aquifer and in streams draining the High Plains in Kansas, Oklahoma, and Texas.

Regionally, the High Plains aquifer is a water-table aquifer consisting mainly of near-surface sand and gravel deposits. Saturated thickness of the aquifer ranges from zero (mainly near the western edge) to about 1,000 feet in west-central Nebraska and a small area in Wyoming. Saturated thickness of the aquifer averages 200 feet, and the total volume of saturated aquifer material is 21.8 billion acre-ft.

Sediments comprising the aquifer control the hydraulic conductivity and specific yield of the aquifer. Because the distribution of sediment types varies both horizontally and vertically, hydraulic conductivity and specific yield also are variable. Based on an analysis of the vertical variation in sediment types, it was concluded that the vertical distribution of sediments is random. Therefore, for purposes of simulating regional ground-water flow, the aquifer system can be represented as two-dimensional, and average values of hydraulic conductivity and specific yield can be used. Hydraulic conductivity ranges from less than 25 to 300 $\mathrm{ft} / \mathrm{d}$ and averages $60 \mathrm{ft} / \mathrm{d}$. Specific yield ranges from less than 5 to 30 percentand averages about 15 percent. A complex areal distribution of aquifer parameters results from the complex fluvial depositional history of the aquifer.

Ground water generally flows from west to east in the High Plains aquifer, at an average rate of about $1 \mathrm{ft} / \mathrm{d}$; it discharges naturally to streams and springs. Ground water is the major component of streamflow 
for the Platte River drainage in Nebraska. Natural discharge of ground water by evapotranspiration also occurs where the water table is near land surface, especially in the sand hills of Nebraska.

Precipitation is the principal source of recharge to the High Plains aquifer. Because potential evapotranspiration greatly exceeds precipitation, recharge to the aquifer generally is small. Estimated recharge rates range from 0.024 inch per year in Texas to 6 inches per year in south-central Kansas. Typically, recharge estimates are greatest in areas with sandy soils. Watertable altitude data indicate that sand-dune areas are important recharge areas. The long-term average annual recharge rate is probably a few tenths of an inch, except in sand-dune areas.

The High Plains aquifer contained about 3.25 billion acre-ft of drainable water in 1980 . About 66 percent of the water in storage is in Nebraska, and about 12 percent is in Texas. New Mexico, the State with the smallest water resource in the High Plains, has only 1.5 percent of the volume of drainable water in storage.

The quality of water in the High Plains aquifer generally is suitable for irrigation use; however, the water does not meet U.S. Environmental Protection Agency drinking water regulations in many places. The concentrations of dissolved solids, fluoride, chloride, and sulfate exceed drinking-water regulations in parts of the aquifer in all States.

In general, ground water in the High Plains aquifer containing less than $250 \mathrm{mg} / \mathrm{L}$ dissolved solids is calcium bicarbonate type water; sodium and sulfate are more prevalent at concentrations of $500 \mathrm{mg} / \mathrm{L}$. Ground water exceeding $500 \mathrm{mg} / \mathrm{L}$ dissolved solids generally is a mixed type, with calcium, sodium, sulfate, and chloride most prevalent. About 62 percent of the area of the High Plains aquifer contains water with 250 to $500 \mathrm{mg} / \mathrm{L}$ dissolved solids; only about 3 percent of the area of the aquifer contains water exceeding $1,000 \mathrm{mg} /$ $\mathrm{L}$ dissolved solids, most of which is in Texas. Generally, dissolved-solids concentrations are least in areas covered by sand, because recharge is relatively high and the sand contains few readily soluble minerals.

Bedrock underlying the aquifer affects the chemical composition of water in the aquifer in parts of all States in the High Plains. Water at the base of the aquifer in contact with the bedrock can dissolve minerals and transport solutes through the aquifer by ground-water flow and diffusion. Water containing excessive concentrations of solutes within the bedrock can flow from the bedrock into the aquifer in response to hydraulichead differences. Also, dissolution of minerals from reworked bedrock material contained in the aquifer since deposition can affect water chemistry. In most areas of the High Plains aquifer, where concentration of dis- solved solids exceeds $1,000 \mathrm{mg} / \mathrm{L}$, chemical composition of the water is affected by underlying bedrock.

Concentration of dissolved solids exceeds $500 \mathrm{mg} / \mathrm{L}$ along the Arkansas, Platte, and Republican Rivers because of irrigation practices. Salts that accumulate in the soil from evapotranspiration are flushed with irrigation water and carried to the aquifer in the stream valleys where the water table is near land surface.

Sodium concentrations in water from the aquifer generally are less than $100 \mathrm{mg} / \mathrm{L}$. About 56 percent of the area of the aquifer contains water with less than 25 $\mathrm{mg} / \mathrm{L}$ sodium; only 3 percent of the area contains water exceeding $100 \mathrm{mg} / \mathrm{L}$ sodium, most of which is in Texas. Concentration of sodium varies in response to the same factors that affect the concentration of dissolved solids. In parts of the southern High Plains of Texas, anomalously large concentrations of dissolved solids and sodium caused by surface disposal of oilfield brines have been reported.

About 95 percent of all water pumped from the High Plains aquifer is used for irrigation. Ground-water irrigation began during the late 1800's and developed rapidly after the drought of the 1930's. Development of the center-pivot system allowed areas to be irrigated during the 1960's that previously were not suitable because of sandy soils and rolling terrain. By 1978, the reported number of acres irrigated in the High Plains was 13 million, and about 170,000 wells pumped an estimated 23 million acre-ft of water for irrigation.

Annual pumpage is from 2 to 100 times greater than recharge in parts of the High Plains. Consequently, water in the aquifer is removed considerably faster than it is replenished. Water levels have declined more than 100 feet from predevelopment to 1980 in parts of Kansas, New Mexico, Oklahoma, and Texas, including 2 percent $\left(2,500 \mathrm{mi}^{2}\right)$ of the area of the aquifer. Water levels have declined more than 50 feet in 7 percent $\left(12,000 \mathrm{mi}^{2}\right)$ and more than 10 feet in 29 percent $(50,000$ $\mathrm{mi}^{2}$ ) of the area of the aquifer.

Volume of water in storage in the aquifer has decreased 166 million acre-ft since ground-water development began. About 16 percent of the depletion has occurred in Kansas; about 70 percent of the depletion has occurred in Texas.

Water-level declines increase pumping lift, decrease well yields, and limit development of the ground-water resource. In addition, physical, chemical, economic, and legal constraints control where the aquifer has been (or can be) developed.

Well yields, which are controlled by the physical characterisitics of the aquifer, limit development to those areas where adequate yields can be obtained. Well yields greater than $750 \mathrm{gal} / \mathrm{min}$ generally can be obtained throughout large areas in all States in the 
High Plains. Only wells yielding less than $250 \mathrm{gal} / \mathrm{min}$ can be obtained where the saturated thickness is thin near the edge of the aquifer, or where water-level declines have greatly decreased the saturated thickness.

Chemical quality of water in the aquifer may limit irrigation development in some areas. Areas of high-salinity hazard occur in Colorado, Kansas, Oklahoma, New Mexico, Texas, and Wyoming. In these areas, water from the High Plains aquifer may not be suitable for irrigation on soils with poor drainage.

Depth to water below land surface affects the cost of pumping water for irrigation. In 1979, the estimated cost of pumping 1 acre- $\mathrm{ft}$ of water with 100 feet of lift was about $\$ 10.00$ for electricity and $\$ 6.00$ for natural gas. These costs are expected to double for electricity and increase 6-fold for natural gas by 1990 . Thus, declining water levels and increasing energy costs may have a serious impact on the economics of future irrigation development. Depth to water in the High Plains aquifer already is greater than 300 feet in parts of Kansas, New Mexico, and Texas.

Legal restraints also control development of ground water. Regulations controlling ground-water development vary between States and within some States. In Texas, ground water is owned and controlled by the landowner. In Oklahoma, ground water is owned by the landowner, but development is controlled by the State. In the other six States, the water is dedicated to the people of the State and administered by the State and local management districts. Future development of the High Plains aquifer will be controlled by the laws of the States in the High Plains.

\section{SELECTED REFERENCES}

Ahlbrandt, T. S., and Fryberger, S. G., 1980, Eolian deposits in the Nebraska sand hills, in Geologic and paleoecologic studies of the Nebraska sand hills: U.S. Geological Survey Professional Paper 1120-A, p. 1-24.

Ashworth, J. B., 1980, Evaluating the ground-water resources of the High Plains of Texas, results of test hole drilling: Texas Department of Water Resources LP 129, 41 p.

Baker, Jr., E. T., and Wall, J. R., 1976, Summary appraisals of the Nation's ground-water resources-Texas-Gulf Region: U.S. Geological Survey Professional Paper 813-F, 29 p.

Barker, R. A., Dunlap, L. E., and Sauer, C. G.,1983, Analysis and computer simulation of stream-aquifer hydrology of the Arkansas River Valley, southwestern Kansas: U.S. Geological Survey Water-Supply Paper 2200, 59 p.

Bassett, R. L., Perkins, S. G., and Waddell, R. K., 1980, Preliminary data describing the distribution of fluoride and silica in the Ogallala aquifer on the High Plains of Texas: U.S. Geological Survey Open-File Report 80-349, $109 \mathrm{p}$.

Bayne, C. K., 1976, Guidebook: Midwestern Friends of the Pleistocene Annual Meeting, 24th, Liberal, Kansas, May 22-23, 1976, State Geological Survey of Kansas Guidebook Series 1, p. 1-85.

Bedinger, M. S., and Sniegocki, R. T., 1976, Summary appraisals of the Nation's ground-water resources-Arkansas-White-Red
Region: U.S. Geological Survey Professional Paper 813-H, 31 p.

Bentall, Ray, and Shaffer, F. B., 1979, Availability and use of water in Nebraska, 1975: Conservation and Survey Division, Institute of Agriculture and Natural Resources, University of NebraskaLincoln, Nebraska Water Survey Paper 48, $121 \mathrm{p}$.

Bittinger, M. W., and Green, E. B., 1980, You never miss the water till ... (the Ogallala story): Littleton, Colorado, Water Resources Publications, $116 \mathrm{p}$.

Blodgett, R. H., 1974, Comparison of Oligocene and modern braided stream sedimentation on the High Plains: Lincoln, University of Nebraska, Unpublished M.S. thesis, $58 \mathrm{p}$.

Blodgett, R. H., and Stanley, K. O., 1980, Stratification, bedforms and discharge relations of the Platte braided river system, Nebraska: Journal of Sedimentary Petrology, v. 50, no. 1, p. 139148.

Boettcher, A. J., 1964, Geology and ground-water resources in Eastem Cheyenne and Kiowa Counties, Colorado: U.S. Geological Survey Water-Supply Paper 1779-N, 32 p.

Bonnen, C. A., McArthur, W. C., Magee, A. C., and Hughes, W. F., 1952, Use of irrigation water on the High Plains: Texas Agricultural Experiment Station Bulletin 756, 43 p.

Borchert, W. B., 1977, Preliminary digital model of the Arikaree aquifer in the Sweetwater River basin, central Wyoming: U.S. Geological Survey Water-Resources Investigations 77-107, 19 p.

Borman, R. G., and Major, T. J., 1977, Water-level changes in the northern High Plains of Colorado, 1964 to 1976 and 1972 to 1976: U.S. Geological Survey Water-Resources Investigations 77-42, map, scale 1:500,000.

Bradbury, J. P., 1980, Late Quaternary vegetation history of the central Great Plains and its relationship to eolian processes in the Nebraska sand hills, in Geologic and paleoecologic studies of the Nebraska sand hills: U.S. Geological Survey Professional Paper 1120-C, p. 29-36.

Breyer, John, 1975, The classification of Ogallala sediments in western Nebraska, in Studies on Cenozoic paleontology and stratigraphy, Claude W. Hibbard Memorial, v. 3: Museum of Paleontology, University of Michigan, Papers on Paleontology no. 12, p. $1-8$.

Brown, R. F., and Signor, D. C., 1973, Artificial-recharge experiments and operations on the southern High Plains of Texas and New Mexico: U.S. Geological Survey Water-Resources Investigations $10-73,54 \mathrm{p}$.

Brutsaert, Willem, Gross, G. W., and McGehee, R. M., 1975, C. E. Jacob's study on the prospective and hypothetical future of the mining of the ground water deposited under the southern High Plains of Texas and New Mexico: Ground Water, v. 13, no. 6 , p. $492-505$.

Bryson, W. R., 1972, Source determination of mineralization in Quaternary aquifers of west-central Kansas: International Geological Congress, 24th Session, Montreal, Canada, 1972, Proceedings, Hydrogeology Section, v. 11, p. 264-269.

Burchett, R. R., 1969, Geologic bedrock map of Nebraska: Conservation and Survey Division, University of Nebraska, scale 1:1,000,000.

Cady, R. C., 1940, Ground-water recharge in areas of deep watertable in the Great Plains: American Geophysical Union Annual Meeting, 21st, Washington, D.C., 1940, Transactions, pt. 2, p. $570-574$.

Cardwell, W. D. E., and Jenkins, E. D., 1963, Ground-water geology and pump irrigation in Frenchman Creek basin above Palisade, Nebraska, with a section on The chemical quality of the water by E. R. Jochens and R. A. Krieger: U.S. Geological Survey Water-Supply Paper 1577, 472 p. 
Carlisle, J. W., and Marrs, R. W., 1982, Airflow over part of the southern High Plains interpreted from Landsat imagery, in Marrs, R. W., and Kolm, K. E., eds., The interpretation of eolian processes and windflow patterns from eolian landforms: Geological Society of America Special Paper 192, p. 89-105.

Carr, J. E., and Bergman, D. L., 1976, Reconnaissance of the water resources of the Clinton quadrangle, west-central Oklahoma: Oklahoma Geological Survey Hydrologic Atlas 5.

Comptroller General of the United States, 1977, Ground water-An overview: U.S. General Accounting Office, CED-77-69, 46 p.

1980, Ground water overdrafting must be controlled: U.S. General Accounting Office, CED-80-96, 52 p.

Crist, M. A., 1977, Hydrologic evaluation of the Arikaree Formation near Lusk, Niobrara and Goshen Counties, Wyoming: U.S. Geological Survey Water-Resources Investigations 77-111, $23 \mathrm{p}$.

1980, Effect of pumpage on ground-water levels as modeled in Laramie County, Wyoming: U.S. Geological Survey WaterResources Investigations 80-1104, 26 p.

Cronin, J. G., 1964, A summary of the occurrence and development of ground water in the southern High Plains of Texas: U.S. Geological Survey Water-Supply Paper 1693, 88 p.

1969, Ground water in the Ogallala Formation in the southern High Plains of Texas and New Mexico: U.S. Geological Survey Hydrologic Investigations Atlas HA-330.

Crowley, K. D., 1981, Large-scale bedforms in the Platte River downstream from Grand Island, Nebraska; Structure, process, and relationship to channel narrowing: U.S. Geological Survey Open-File Report 81-1059, $31 \mathrm{p}$.

Dane, C. H., and Bachman, G. O., 1965, Geologic map of New Mexico: U.S. Geological Survey, scale 1:500,000.

Darton, N. H., 1951, Geologic map of South Dakota: U.S. Geological Survey, scale 1:500,000.

Darton, N. H., Stephenson, L. W., and Gardner, J. A., 1937, Geologic map of Texas: U.S. Geological Survey, scale 1:500,000.

Dinwiddie, G. A., 1963, Municipal water supplies and uses, southeastern New Mexico: New Mexico State Engineer Technical Report $29 \mathrm{~A}, 140 \mathrm{p}$.

Dix, R. L., 1964, A history of biotic and climatic changes within the North American grassland, in Crisp, D. J., ed., Grazing in terrestrial and marine environment: Dorking, Great Britain, Blackwell Scientific Publications, p. 71-89.

Dunham, R. J., 1961, Geology of uranium in Chadron area Nebraska and South Dakota: U.S. Geological Survey open-file report, plate 1 , scale $1: 48,000$.

Dunlap, L. E., Kume, Jack, and Thomas, J. G., 1980, Geohydrology and model analysis for water-supply management in a small area of west-central Kansas: U.S. Geological Survey Water-Resources Investigations 80-91, $59 \mathrm{p}$.

Ellis, M. J., and Adolphson, D. G., 1971, Hydrology of the Pine Ridge Indian Reservation, South Dakota: U.S. Geological Survey Hydrologic Investigations Atlas HA-357.

Ellis, M. J., Ficken, J. H., and Adolphson, D. G., 1971, Hydrology of the Rosebud Indian Reservation, South Dakota: U.S. Geological Survey Hydrologic Investigations Atlas HA-355.

Emery, P. A., 1966, Use of analog model to predict streamflow depletion, Big and Little Blue River basin, Nebraska: Ground Water, v. 4 , no. 4 , p. 13-19

Engberg, R. A., and Spalding, R. F., 1978, Groundwater quality atlas of Nebraska: Conservation and Survey Division, Institute of Agriculture and Natural Resources, University of NebraskaLincoln, Resource Atlas 3, $39 \mathrm{p}$.

Fader, S. W., Gutentag, E. D., Lobmeyer, D. H., and Meyer, W. R., 1964, Geohydrology of Grant and Stanton Counties, Kansas: Kansas Geological Survey Bulletin 168, 147 p.
Feder, G. L., and Krothe, N. C., 1981, Results of a reconnaissance water-quality sampling program of the Ogallala aquifer in Colorado, Kansas, Nebraska, Oklahoma, South Dakota, and Texas: U.S. Geological Survey Water-Resources Investigations 81-65, 7 p.

Fenneman, N. M., 1931, Physiography of western United States (1st ed.): New York, McGraw-Hill, 534 p.

Finley, R. J., and Gustavson, T. C., 1979, Analyses of surface linear elements and jointing, Texas Panhandle: University of Texas, Bureau of Economic Geology Geological Circular 79-1, p. 78-86.

1981, Lineament analysis based on Landsat imagery, Texas Panhandle: University of Texas, Bureau of Economic Geology Geological Circular 81-5, $37 \mathrm{p}$.

Freeze, R. A., and Cherry, J. A., 1979, Groundwater: Englewood, New Jersey, Prentice-Hall, $604 \mathrm{p}$.

Frye, J. C., 1970, The Ogallala Formation-A review, in Mattox, R. B., and Miller, W. D., eds., Ogallala aquifer, A symposium: Texas Tech University, Lubbock, 1970, International Center for Arid and Semi-arid Land Studies Special Report no. 39, p. 5-14.

Gammon, S. W., and Muse, W. R., 1966, Water-level data from observation wells in the southern High Plains of Texas: Texas Water Development Board Report 21, $537 \mathrm{p}$.

Gilbert, G. K., 1896, The underground water of the Arkansas Valley in eastern Colorado: U.S. Geological Survey 17th Annual Report, pt. 2, p. 551-601.

Gillespie, J. B., and Slagle, S. E., 1972, Natural and artificial groundwater recharge, Wet Walnut Creek, central Kansas: Kansas Water Resources Board Bulletin 17, $94 \mathrm{p}$.

Green, D. E., 1973, Land of the underground rain: Austin, University of Texas Press, $295 \mathrm{p}$.

Grubb, H. W., 1978, High Plains study: Groundwater Management Districts Association Conference, 5th, Amarillo, Texas, December 6-8, 1978, Proceedings, p. 3-12.

Gustavson, T. C., 1980a, Rates of salt dissolution: University of Texas Bureau of Economic Geology Geological Circular 80-7, p. 71-75.

1980b, Faulting and salt dissolution, Texas: University of Texas Bureau of Economic Geology Geological Circular 80-7, p. 83-87.

Gustavson, T. C., Finley, R. J., and McGillis, K. A., 1980, Regional dissolution of Permian salt in the Anadarko, Dalhart, and Palo Duro basins of the Texas Panhandle: University of Texas, Bureau of Economic Geology Report of Investigations no. 106, 40 p.

Gutentag, E. D., 1963, Studies on the Pleistocene and Pliocene deposits in southwestern Kansas: Transactions of the Kansas Academy of Science, v. 66, no. 44, p. 606-621.

Gutentag, E. D., Lobmeyer, D. H., and Slagle, S. E., 1981, Geohydrology of southwestern Kansas: Kansas Geological Survey Irrigation Series 7, $73 \mathrm{p}$.

Gutentag, E. D., and Stullken, L. E., 1976, Ground-water resources of Lane and Scott Counties, western Kansas: Kansas Geological Survey Irrigation Series no. 1, $37 \mathrm{p}$.

Gutentag, E. D., and Weeks, J. B., 1980, Water table in the High Plains aquifer in 1978 in parts of Colorado, Kansas, Nebraska, New Mexico, Oklahoma, South Dakota, Texas, and Wyoming: U.S. Geological Survey Hydrologic Investigations Atlas HA-642. 1981 , Evaluating vertical variability of transmissivity and specific yield for the High Plains regional aquifer system [abs.]: Geological Society of America Abstracts with Programs, Rocky Mountain Section, v. 13, no. 4, p. 199.

Harksen, J. C., and Macdonald, J. R., 1969, Guidebook to the major Cenozoic deposits of southwestern South Dakota: South Dakota Geological Survey Guidebook No. 2, 103 p. 
Hart, D. L., Jr., Hoffman, G. L., and Goemaat, R. L., 1976, Geohydrology of the Oklahoma Panhandle, Beaver, Cimarron, and Texas Counties: U.S. Geological Survey Water-Resources Investigations $25-75,62 \mathrm{p}$.

Hathaway, L. R., Carr, B. L., Galle, O. K., Magnuson, L. M., Waugh, T. C., and Dickey, H. P., 1977, Chemical quality of irrigation waters in Hamilton, Kearny, Finney, and northern Gray Counties: Kansas Geological Survey Chemical Quality Series 4, $33 \mathrm{p}$.

Hathaway, L. R., Galle, O. K., Waugh, T. C., and Dickey, H. P., 1978, Chemical quality of irrigation waters in Ford County and the Great Bend Prairie of Kansas: Geological Survey Chemical Quality Series 7, $41 \mathrm{p}$.

Havens, J. S., 1966, Recharge studies on the High Plains in northern Lea County, New Mexico: U.S. Geological Survey Water-Supply Paper 1819-F, 52 p.

Heimes, F. J., and Luckey, R. R., 1980, Evaluating methods for determining water use in the High Plains in parts of Colorado, Kansas, Nebraska, New Mexico, Oklahoma, South Dakota, Texas, and Wyoming, 1979: U.S. Geological Survey Water-Resources Investigations $80-111,118 \mathrm{p}$.

1982, Method for estimating historical irrigation requirements from ground water in the High Plains in parts of Colorado, Kansas, Nebraska, New Mexico, Oklahoma, South Dakota, Texas, and Wyoming: U.S. Geological Survey Water-Resources Investigations $82-40,64 \mathrm{p}$.

1983, Estimating 1980 ground-water pumpage for irrigation on the High Plains in parts of Colorado, Kansas, Nebraska, New Mexico, Oklahoma, South Dakota, Texas, and Wyoming: U.S. Geological Survey Water-Resources Investigations 83-4123, 36 p.

Hem, J. D., 1970, Study and interpretation of the chemical characteristics of natural water: U.S. Geological Survey Water-Supply Paper 1473, $363 \mathrm{p}$.

Hibbard, C. W., 1960, An interpretation of Pliocene and Pleistocene climates in North America: Michigan Academy of Science, Arts, and Letters, 62nd Annual Report, p. 5-30.

High Plains Associates, 1982, Six-state High Plains Ogallala aquifer regional resources study, A report to the U.S. Department of Commerce and the High Plains Study Council: Austin, Texas, $438 \mathrm{p}$.

Hill, R. T., 1894, Geology of parts of Texas, Indian Territory and Arkansas adjacent to Red River region: Geological Society of America Bulletin, v. 5, p. 297-338.

Hughes, W. F., and Magee, A. C., 1960, Some economic effects of adjusting to a changing water supply: Texas Agricultural Experiment Station Bulletin 966, 27 p.

Huntoon, P. W., 1974, Predicted water-level declines for alternative groundwater developments in the upper Big Blue River basin, Nebraska: Conservation and Survey Division, Institute of Agricultural and Natural Resources, University of Nebraska-Lincoln, Resource Report no. 6, 106 p.

Irwin, J. H., and Morton, R. B, 1969, Hydrogeologic information on the Glorieta Sandstone and the Ogallala Formation in the Oklahoma Panhandle and adjoining areas as related to underground waste material: U.S. Geological Survey Circular 630, 26 p.

Izett, G. A., 1975, Late Cenozoic sedimentation and deformation in northern Colorado and adjoining areas in Curtis, B. F., ed., Cenozoic history of the southern Rocky Mountains: Geological Society of America Memoir 144, p. 179-209.

Jenkins, E. D., and Pabst, M. E., 1975, Water development for irrigation in northwestern Kansas: U.S. Geological Survey OpenFile Report 4-75, $39 \mathrm{p}$.

Johnson, A. I., 1967, Specific yield-Compilation of specific yields for various materials: U.S. Geological Survey Water-Supply Paper 1662-D, $74 \mathrm{p}$.

Johnson, K. S., 1981, Dissolution of salt on the east flank of the Permian basin in the southwestern U.S.A.: Journal of Hydrology, v. 54 , p. $75-93$.

Johnson, M. S., and Pederson, D. T., 1980, Groundwater levels in Nebraska, 1979: Conservation and Survey Division, Institute of Agriculture and Natural Resources, University of Nebraska-Lincoln, Nebraska Water Supply Paper no. 50, 65 p.

Johnson, W. D., 1901, The High Plains and their utilization: U.S. Geological Survey 21st Annual Report, pt. 4-C, p. 601-741.

Jordan, P. R., 1977, Streamflow transmission losses in western Kansas: Proceedings of the American Society of Civil Engineers, Journal of the Hydraulies Division, v. 103, no. HY8, Paper 13156, p. 905-919.

Kansas Geological Survey, 1964, Geologic map of Kansas: Kansas Geological Survey map M-1, scale 1:500,000.

Kapple, G. W., Luckey, R. R., and Hofstra, W. E., 1977, Digital ground-water model of the Ogallala aquifer in parts of Cheyenne and Kiowa Counties, northern High Plains of Colorado: Colorado Water Conservation Board, Water Resources Circular 35, 20 p.

Kessler, L. G., II, 1971, Characteristics of the braided stream depositional environment with examples from the South Canadian River, Texas: Wyoming Geological Association Earth Science Bulletin, v. 4, no. 1, p. 25-35.

King, Clarence, 1878, Systematic geology: U.S. Geological Exploration of the 40th Parallel Report, v. 1, 803 p.

King, P. B., 1959, The evolution of North America: Princeton, New Jersey, Princeton University Press, $190 \mathrm{p}$.

Krothe, N. C., and Oliver, J. W., 1979, The hydrogeochemistry of the Oklahoma section of the High Plains [abs.]: Geological Society of America Abstracts with Programs, v. 11, p. 461.

1982, Sulphur isotopic composition and water chemistry in water from the High Plains aquifer, Oklahoma Panhandle and southwestern Kansas: U.S. Geological Survey Water-Resources Investigations 82-12, $28 \mathrm{p}$.

Krothe, N. C., Oliver, J. W., and Weeks, J. B., 1982, Dissolved solids and sodium in water from the High Plains aquifer in parts of Colorado, Kansas, Nebraska, New Mexico, Oklahoma, South Dakota, Texas, and Wyoming: U.S. Geological Survey Hydrologic Investigations Atlas HA-658.

Lansford, R. R., Brutsaert, Willem, Creel, B. J., Flores, Adam, and Loo, Walter, 1974, Water resources evaluation of the southern High Plains of New Mexico: New Mexico Water Resources Research Institute, WRRI Report no. 044, 59 p.

Lappala, E. C., 1978, Quantitative hydrogeology of the Upper Republican natural resources district, southwest Nebraska: U.S. Geological Survey Water-Resources Investigations 78-38, 200 p.

Lohman, S. W., 1953, High Plains of west-central United States, general aspects, chapter 4 of Subsurface facilities of water management and patterns of supply-type area studies, v. 4 of The Physical and economic foundation of natural resources: U.S. $83 \mathrm{~d}$ Congress, House Committee on Interior and Insular Affairs, p. $70-78$.

1972, Ground-water hydraulies: U.S. Geological Survey Professional Paper 708, $70 \mathrm{p}$.

Longenbaugh, R. A., and Krishnamurthi, N., 1975, Computer estimates of natural recharge from soil moisture data, High Plains of Colorado: Fort Collins, Colorado State University, Environmental Resources Center Series no. 64, 58 p.

Love, J. D., Weitz, J. L., and Hose, R. K., 1955, Geologic map of Wyoming: U.S. Geological Survey, scale 1:500,000.

Lowry, M. E., Crist, M. A., and Tilstra, J. R., 1967, Geology and ground-water resources of Laramie County, Wyoming: U.S. 
Geological Survey Water-Supply Paper 1834, 71 p.

Luckey, R. R., and Ferrigno, C. F., 1982, A data management system for areal interpretive data for the High Plains in parts of Colorado, Kansas, Nebraska, New Mexico, Oklahoma, South Dakota, Texas, and Wyoming: U.S. Geological Survey WaterResources Investigations 82-4072, $112 \mathrm{p}$.

Luckey, R. R., Gutentag, E. D., and Weeks, J. B., 1981, Water-level and saturated-thickness changes, predevelopment to 1980 , in the High Plains aquifer in parts of Colorado, Kansas, Nebraska, New Mexico, Oklahoma, South Dakota, Texas, and Wyoming: U.S. Geological Survey Hydrologic Investigations Atlas HA-652.

Luckey, R. R., Heimes, F. J., and Gaggiani, N. G., 1980, Calibration and testing of selected portable flowmeters for use on large irrigation systems: U.S. Geological Survey Water-Resources Investigations 80-72, $21 \mathrm{p}$.

Lugn, A. L., 1938, The Nebraska State Geological Survey and the "Valentine problem": American Journal of Science, 5th series, v. 36 , no. 213 , p. $220-227$.

1962, The origin and sources of loess: Lincoln, University of Nebraska Studies, New Series no. 26, 104 p.

MacGinitie, H. D., 1962, The Kilgore flora, a late Miocene flora from northern Nebraska: University of California Publications in Geological Science, v. 35, no. 2, p. 67-158.

McCall, K. D., 1944, Growth of irrigation in Scott County: Kansas State Board of Agriculture Report, v. 63, no. 262, p. 1-31.

McGovern, H. E., 1964, Geology and ground-water resources of Washington County, Colorado: U.S. Geological Survey WaterSupply Paper 1777, 46 p.

McGovern, H. E., and Coffin, D. L., 1963, Potential ground-water development in the northern part of the Colorado High Plains: Colorado Water Conservation Board, Ground Water Circular 8, 9 p.

MeGovern, H. E., and Long, W. A., 1974, Ground water in Gray County, southwestern Kansas: U.S. Geological Survey Hydrologic Investigations Atlas HA-517.

McLaughlin, T. G., 1946, Geology and ground-water resources of Grant, Haskell, and Stevens Counties, Kansas: Kansas Geological Survey Bulletin 61, $221 \mathrm{p}$.

Madson, John, 1978, Nebraska's sand hills-Land of long sunsets: National Geographic Society, v. 154, no. 4, p. 493-517.

Marine, I. W., 1963, Correlation of water-level fluctuations with climatic cycles in the Oklahoma Panhandle, contributions to the hydrology of the United States: U.S. Geological Survey WaterSupply Paper 1669-K, $10 \mathrm{p}$.

Meyer, W. R., Gutentag, E. D., and Lobmeyer, D. H., 1970, Geohydrology of Finney County, southwestern Kansas: U.S. Geological Survey Water-Supply Paper 1891, $117 \mathrm{p}$.

Miall, A. D., 1977, A review of the braided-river depositional environment: Earth-Science Reviews, v. 13, p. 1-62.

Morgan, A. M., 1946, Progress report on geology and ground-water resources of the Cheyenne area, Wyoming: U.S. Geological Survey open-file report, $52 \mathrm{p}$.

Morris, D. A., and Babcock, H. M., 1960, Geology and ground-water resources of Platte County, Wyoming, with a section on Chemical quality of the water, by R. H. Langford: U.S. Geological Survey Water-Supply Paper 1490, 195 p.

Morton, R. B., 1973, Preliminary investigations of the hydrogeology of the Permian to Tertiary rocks of the Oklahoma Panhandle: U.S. Geological Survey Miscellaneous Geological Investigations Map I-738.

-1980, Digital-model projection of saturated thickness and recoverable water in the Ogallala aquifer, Texas County, Oklahoma: U.S. Geological Survey Open-File Report 79-565, 34 p.

Morton, R. B., and Goemaat, R. L., 1973, Reconnaissance of the water resources of Beaver County, Oklahoma: U.S. Geological Survey Hydrologic Investigations Atlas HA-450.
Ore, H. T., 1963, The braided stream depositional environment: Laramie, University of Wyoming, Unpublished Ph.D. dissertation, $197 \mathrm{p}$.

Pabst, M. E., and Jenkins, E. D., 1976, Water-level changes in northwestern Kansas, 1950-76: Kansas Geological Survey Journal, December 1976, $20 \mathrm{p}$.

1979, Water-level changes in southwestern Kansas, 1940-78: Kansas Geological Survey Journal, May 1979, 29 p.

Pabst, M. E., and Jenkins, E. D., 1976, Water-level changes in northwestern Kansas 1950-76: Kansas Geological Survey Journal, December 1976, $20 \mathrm{p}$.

Rapp, J. R., Visher, F. N., and Littleton, R. T., 1957, Geology and ground-water resources of Goshen County, Wyoming: U.S. Geological Survey Water-Supply Paper 1377, 145 p.

Rayner, F. A., and others, 1973, Mathematical management model of parts of the Ogallala aquifer, Texas: High Plains Water Conservation District No. 1 and Texas Tech University Water Resources Center, Final Report OWRR Grant no. 14-31-0001$3363,111 \mathrm{p}$.

Reddell, D. L., 1967, Distribution of ground-water recharge: Fort Collins, Colorado State University, Agricultural Engineering Department Technical Report, $132 \mathrm{p}$.

1970, A mathematical model for determining areal distribution of natural recharge in the northern High Plains of Colorado, in Mattox, R. B., and Miller, W. D., eds., The Ogallala aquifer, A symposium: Texas Tech University, Lubbock, 1970, International Center for Arid and Semi-arid Land Studies Special Report no. 39 , p. $165-181$.

Reeves, C. C., and Miller, W. D., 1978, Nitrate, chloride, and dissolved solids, Ogallala aquifer, west Texas: Ground Water, v. 16, no. 3, p. 167-173.

Reineck, H. E., and Singh, I. B., 1980, Depositional sedimentary environments (2d ed.): Berlin, Heidelberg, New York, SpringerVerlag, $549 \mathrm{p}$.

Rettman, P. L., and Leggat, E. R., 1966, Ground-water resources of Gaines County, Texas: Texas Water Development Board Report $15,185 \mathrm{p}$.

Richards, D. B., Hershey, L. A., and Glanzman, R. K., 1968, Hydrogeologic data from Baca and southern Prowers Counties, Colorado: Colorado Water Conservation Board, Basic-Data Release $19,123 \mathrm{p}$.

Robinson, Peter, 1972, Tertiary history, in Geologic atlas of the Rocky Mountain Region: Denver, Colorado, Rocky Mountain Association of Geologists, p. 233-242.

Sapik, D. B., and Goemaat, R. L., 1973, Reconnaissance of the ground-water resources of Cimarron County, Oklahoma: U.S. Geological Survey Hydrologic Investigations Atlas HA-373.

Schoff, S. L., 1939, Geology and ground water resources of Texas County, Oklahoma: Oklahoma Geological Survey Bulletin No. 59, $248 \mathrm{p}$.

1943, Geology and ground water resources of Cimarron County, Oklahoma: Oklahoma Geological Survey Bulletin No. 64, $317 \mathrm{p}$.

Schultz, C. B., 1968, The stratigraphic distribution of vertebrate fossils in Quaternary eolian deposits in the midcontinent region of North America, in Loess and related eolian deposits of the world: International Association for Quaternary Research, VIIth Congress, U.S. National Academy of Sciences, August 14-September 19, 1965, Proceedings, v. 12, p. 115-138.

Schultz, G. E., 1977, The Ogallala Formation and its vertebrate faunas in the Texas and Oklahoma Panhandles, in Schultz, G. E., ed., Field conference on Late Cenozoic biostratigraphy of the Texas Panhandle and adjacent Oklahoma, August 4-6, 1977, Guidebook: West Texas State University, Department of Geology and Anthropology, Killgore Research Center Special Publication no. 1, p. 5-104. 
Sears, P. B., 1961, A pollen profile from the grassland province: Science, v. 134, p. 2038-2039.

Seni, S. J., 1980, Sand-body geometry and depositional systems, Ogallala Formation, Texas: University of Texas, Bureau of Economic Geology Report of Investigations no. 105, 36 p.

Simpkins, W. W., Gustavson, T. C., Alhades, A. B., and Hoadley, A. D., 1981, Impact of evaporite dissolution and collapse on highways and other cultural features in the Texas Panhandle and eastern New Mexico: Austin, University of Texas, Bureau of Economic Geology Geological Circular 81-4, 23 p.

Slogget, Gordon, 1977, Mining the Ogallala aquifer; State and local efforts in groundwater management: U.S. Department of Agriculture, Agricultural Experiment Station, Oklahoma State University Research Report P-761, $18 \mathrm{p}$.

1981, Prospects for ground-water irrigation: U.S. Department of Agriculture, Agricultural Economic Report 478, 43 p.

Smith, H. T. U., 1940, Geologic studies in southwestern Kansas: Kansas Geological Survey Bulletin 34, 212 p.

1965, Dune morphology and chronology in central and western Nebraska: Journal of Geology, v. 73, no. 4, p. 557-578

Smith, N. D., 1970, The braided stream depositional environment; comparison of the Platte River with some Silurian clastic rocks, north-central Appalachians: Geological Society of America Bulletin, v. 81 , p. 2993-3014.

Sniegocki, R. T., 1959, Geologic and ground-water reconnaissance of the Loup River drainage basin, Nebraska, with a section on The chemical quality of the ground water, by R. H. Langford: U.S. Geological Survey Water-Supply Paper 1493, 106 p.

Sophocleous, Marios, 1980, Hydrogeologic investigations in the Pawnee Valley, Kansas: Kansas Geological Survey Open-File Report no. $61,128 \mathrm{p}$.

Swenson, F. A., 1974, Rates of salt solution in the Permian basin: U.S. Geological Survey Journal of Research, v. 2, no. 2, p. 253257.

Taylor, O. J., 1978, Summary appraisals of the Nation's ground-water resources-Missouri Basin Region: U.S. Geological Survey Professional Paper 813-Q, $41 \mathrm{p}$.

Texas Department of Water Resources, 1981, Publications catalog 81: Texas Department of Water Resources Circular C-12, 275 p.

Theis, C. V., 1934, Progress report on the ground-water supply of Lea County, New Mexico: New Mexico State Engineer, 11th Biennial Report, p. 127-153.

1937, Amount of ground-water recharge in the southern High Plains: Transactions of the American Geophysical Union, v. 18, p. $564-568$.

Thorp, James, Smith, H. T. U., and others, 1952, Pleistocene eolian deposits of the United States, Alaska, and parts of Canada: Geological Society of America, map, scale 1:2,500,000, 2 sheets.

Trimble, D. E., 1980a, Cenozoic tectonic history of the Great Plains contrasted with that of the southern Rocky Mountains-A synthesis: The Mountain Geologist, v. 17, no. 3, p. 59-69.

$1980 \mathrm{~b}$, The geologic story of the Great Plains: U.S. Geological Survey Bulletin 1493, 55 p.

Tweto, Ogden, 1979, Geologic map of Colorado: U.S. Geological Survey, scale $1: 500,000$.

U.S. Department of Agriculture, 1967, Irrigation water requirements: Soil Conservation Service, Engineering Division, Technical Release no. 21, 88 p.

U.S. Department of Commerce, 1949-78, Census of agriculture: Bureau of the Census, agricultural data for 1949, 1954, 1959, 1964, 1969, 1974, and 1978 for Colorado, Kansas, Nebraska, New Mexico, Oklahoma, South Dakota, Texas, and Wyoming.

1977, Climatic atlas of the United States: Environmental Science Services Administration, Environmental Data Service, 80 p.
U.S. Department of the Interior, 1975, Executive summary of critical water problems facing the eleven western States: U.S. Bureau of Reclamation, Washington, D. C., Westwide Study, 85 p.

U.S. Environmental Protection Agency, 1976, National interim primary drinking water regulations: Office of Water Supply, EPA$570 / 9-76-003,159 \mathrm{p}$.

1977, National secondary drinking water regulations: Federal Register, v. 42, no. 62, Thursday, March 31, 1977, Part I, p. 17143-17147.

U.S. Salinity Laboratory Staff, 1954, Diagnosis and improvement of saline and alkali soils: U.S. Department of Agriculture Handbook $60,160 \mathrm{p}$.

Waechter, N. B., 1972, Hydrology, morphology, and sedimentology of an ephemeral braided stream, Prairie Dog Town Fork of the Red River, Texas Panhandle: Austin, University of Texas, Unpublished M.A. thesis, $58 \mathrm{p}$.

Waite, H. A., 1947, Geology and ground-water resources of Scott County, Kansas: Kansas Geological Survey Bulletin 66, 216 p.

Walters, R. F., 1978, Land subsidence in central Kansas related to salt dissolution: Kansas Geological Survey Bulletin 214, 82 p.

Ward, P. E., 1963, Geology and ground-water features of salt springs, seeps, and plains in the Arkansas and Red River basins of western Oklahoma and adjacent parts of Kansas and Texas: U.S. Geological Survey open-file report, $94 \mathrm{p}$.

Watts, W. A., and Wright, H. E., Jr., 1966, Late Wisconsin pollen and seed analysis from the Nebraska sand hills: Ecology, v. 47, no. 2, p. 202-210.

Weeks, E. P., 1964, Hydrologic conditions in the Wheatland Flats area, Platte County, Wyoming: U.S. Geological Survey WaterSupply Paper $1783,79 \mathrm{p}$.

Weeks, J. B., 1978, Plan of study for the High Plains regional aquifer-system analysis in parts of Colorado, Kansas, Nebraska, New Mexico, Oklahoma, South Dakota, Texas, and Wyoming: U.S. Geological Survey Water-Resources Investigations 78-70, $28 \mathrm{p}$.

Weeks, J. B., and Gutentag, E. D., 1981, Bedrock geology, altitude of base, and 1980 saturated thickness of the High Plains aquifer in parts of Colorado, Kansas, Nebraska, New Mexico, Oklahoma, South Dakota, Texas, and Wyoming: U.S. Geological Survey Hydrologic Investigations Atlas HA-648.

Weist, W. G., Jr., 1965, Reconnaissance of the ground-water resources in parts of Larimer, Logan, Morgan, Sedgwick, and Weld Counties, Colorado: U.S. Geological Survey Water-Supply Paper 1809-L, p. 1-24.

White, C. L., and Renner, G. T., 1957, College geography: New York, Appleton-Century-Crofts, 716 p.

White, W. N., Broadhurst, W. L., and Lang, J. W., 1946, Ground water in the High Plains of Texas: U.S. Geological Survey Water-Supply Paper 889-F, p. 381-420.

Williams, C. C., and Lohman, S. W., 1949, Geology and groundwater resources of a part of south-central Kansas with special reference to the Wichita municipal water supply: Kansas Geological Survey Bulletin 79, $455 \mathrm{p}$.

Williams, G. P., 1978, The case of the shrinking channels-The North Platte and Platte Rivers in Nebraska: U.S. Geological Survey Circular 781, $48 \mathrm{p}$.

Winslow, A. G., and Kister, L. R., 1956, Saline-water resources of Texas: U.S. Geological Survey Water-Supply Paper 1365, 105 p.

Wood, P. R., and Hart, D. L., Jr., 1967, Availability of ground water in Texas County, Oklahoma: U.S. Geological Survey Hydrologic Investigations Atlas HA-250.

Zeller, E. J., and others, 1976, Potential uranium host rocks and structures in the central Great Plains: Kansas Geological Survey Geology Series 2, $59 \mathrm{p}$. 